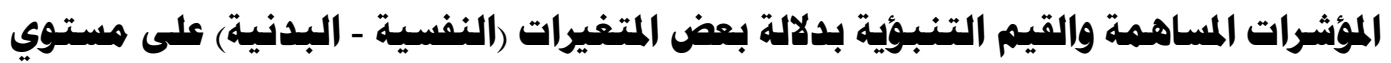

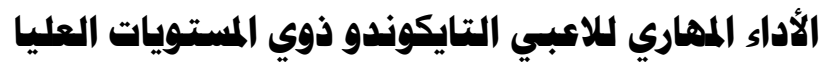

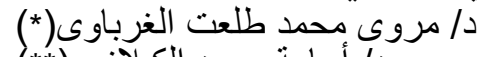

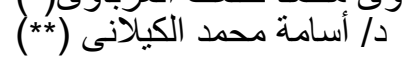

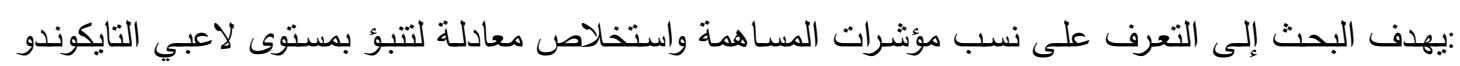

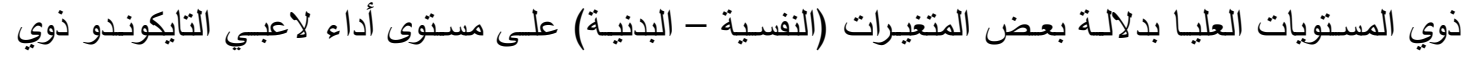

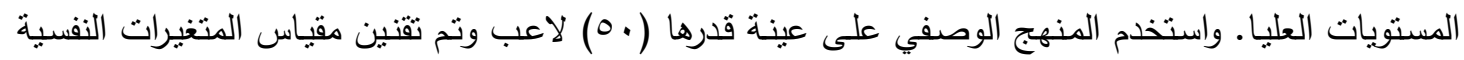

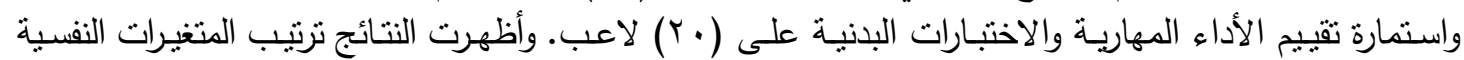

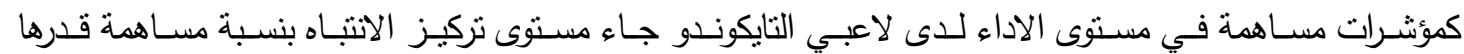

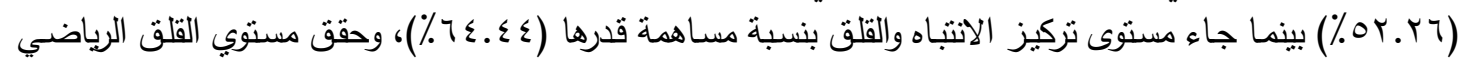

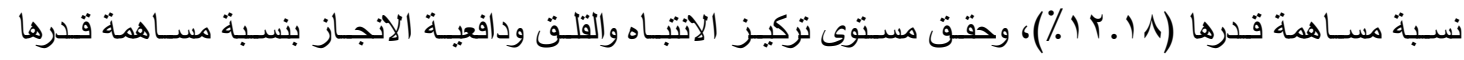

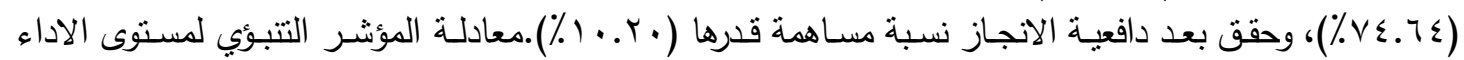

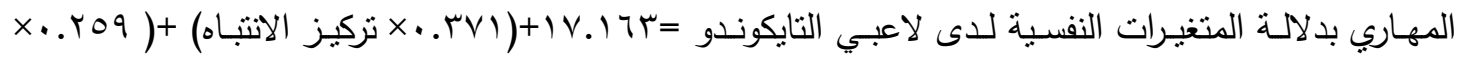

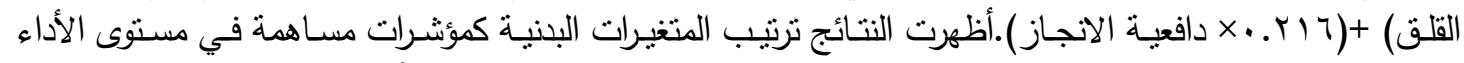

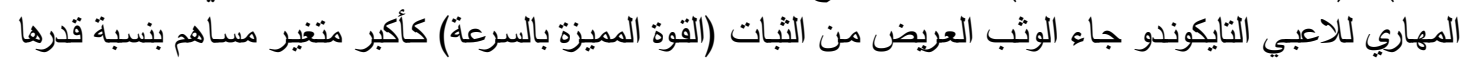

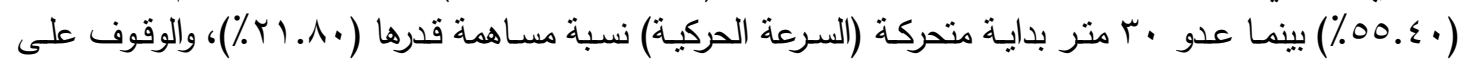

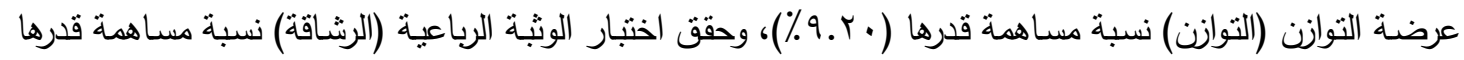

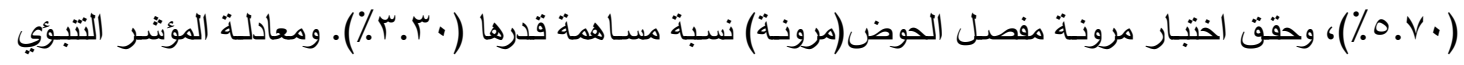

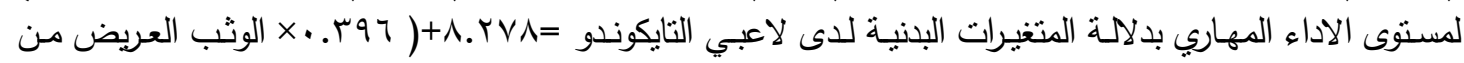

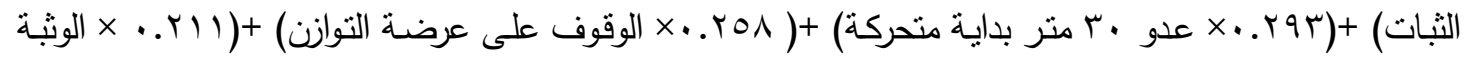

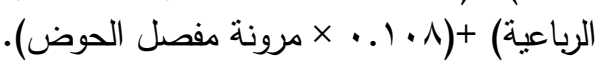
الكلمات الدالة: القلق - دافعية الانجاز - تركيز الانتباهـاللياقة البنية - مهارات التايكوندو 


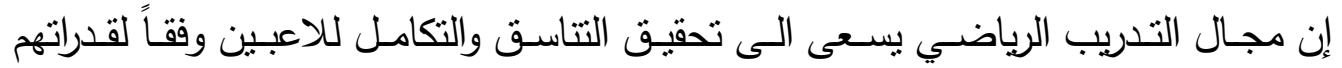

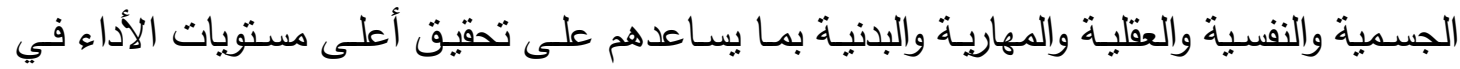
تخصصاتهم المتتوعة وبدون شك يتوقف ذلك على إيجابية إعدادهم من كل الجوانب السابقة خلال

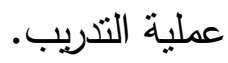
ويجب على كل لاعب أن يستغل كافة قدراته وطاقاته الاستغلال الأمتل من أجل أن يساعده

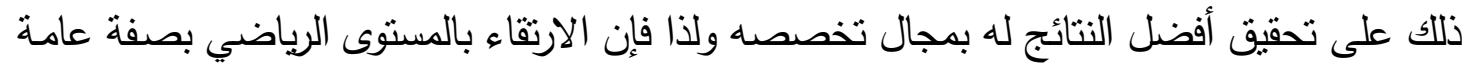

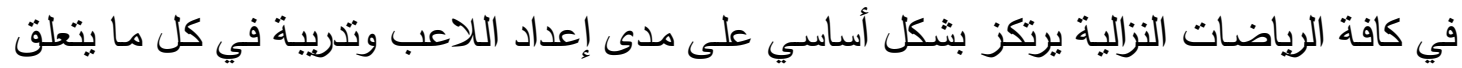

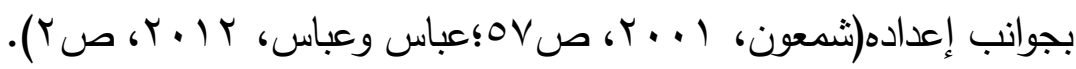

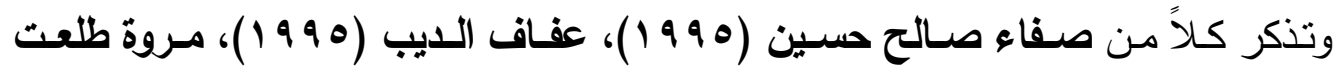

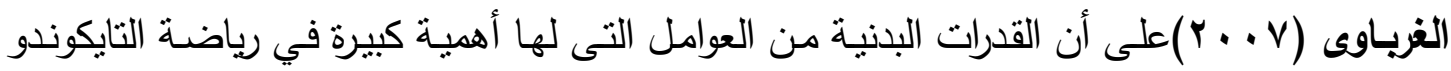

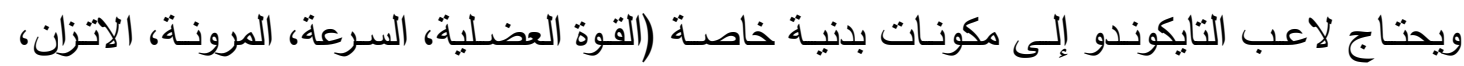

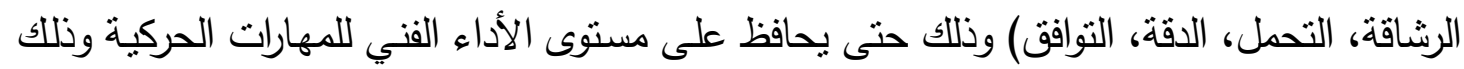

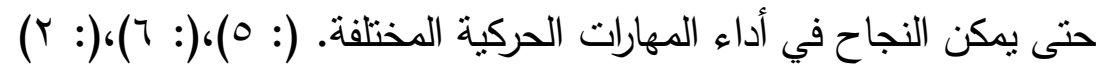

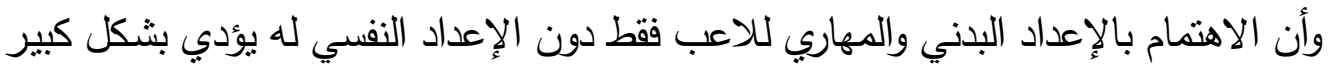

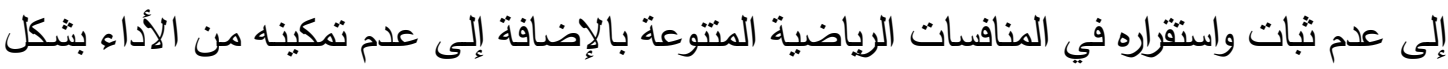

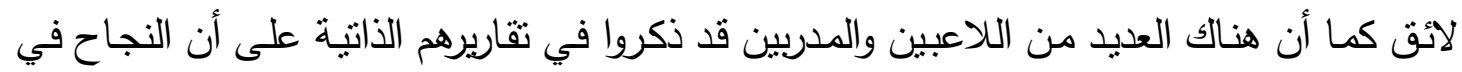

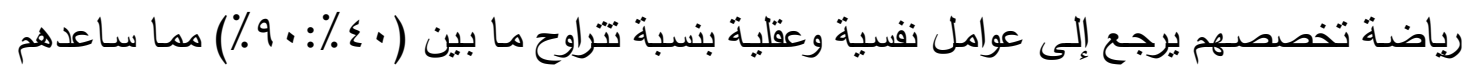

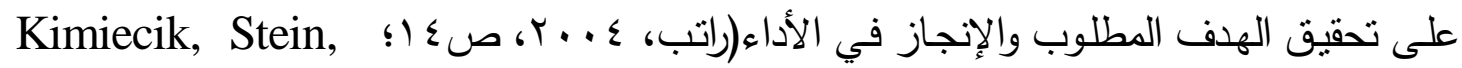
1992, P128

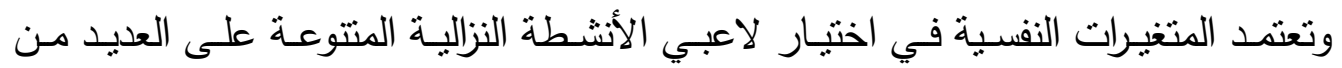

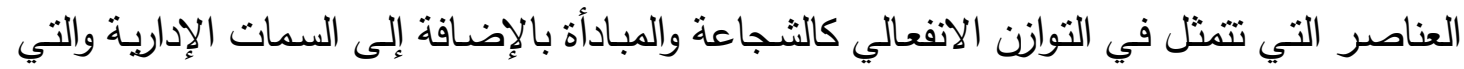

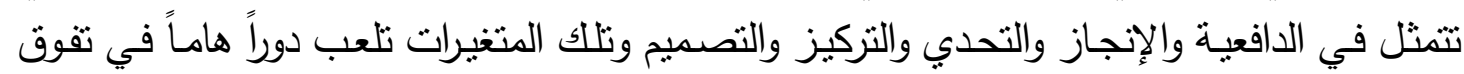

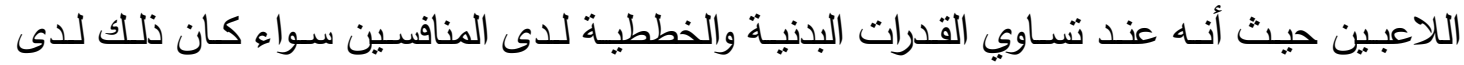

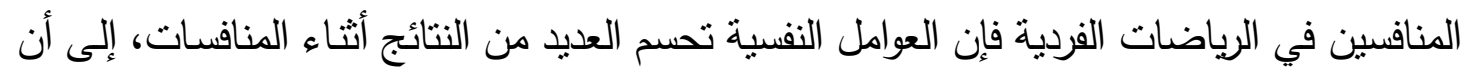

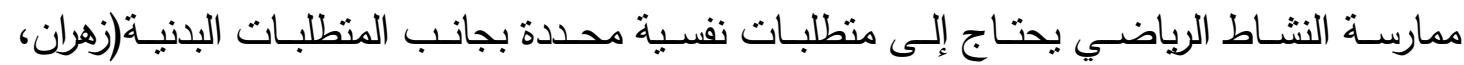

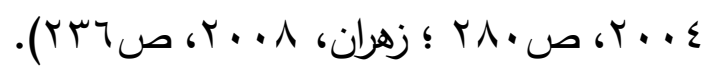

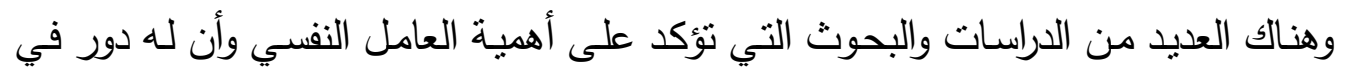

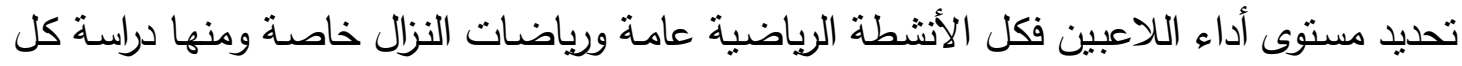

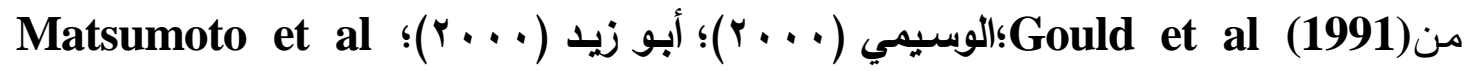

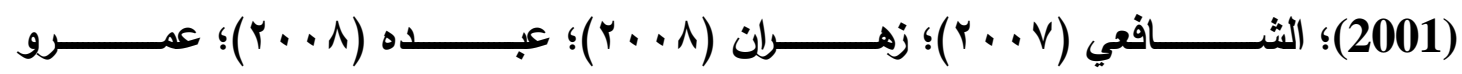

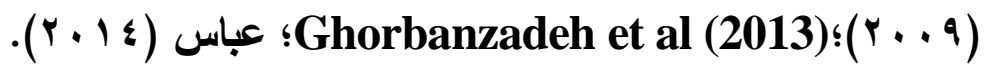

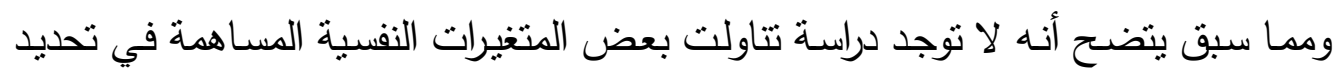

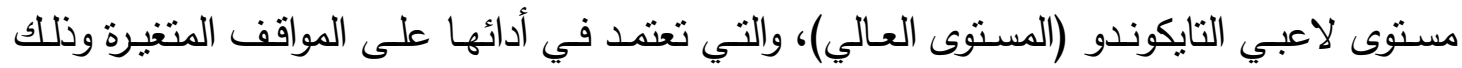




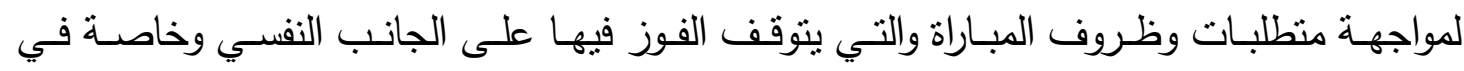

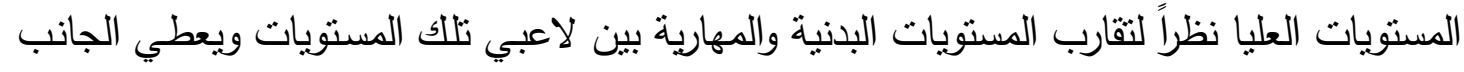

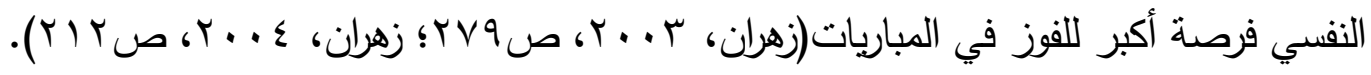

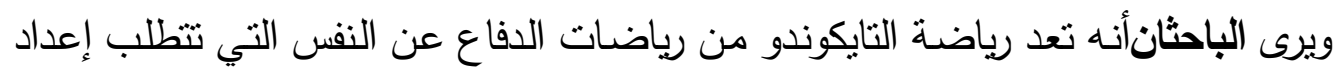

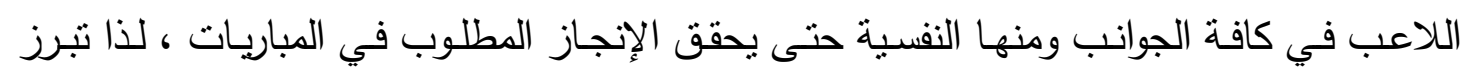

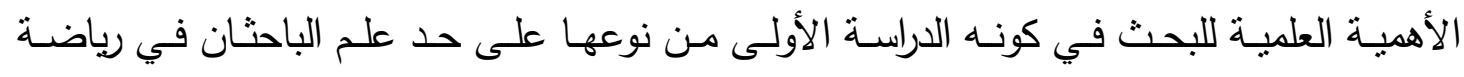

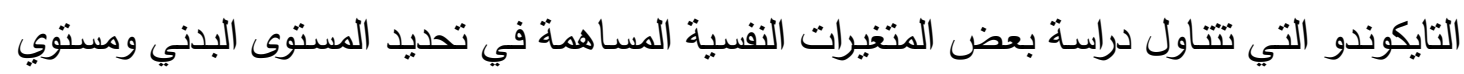

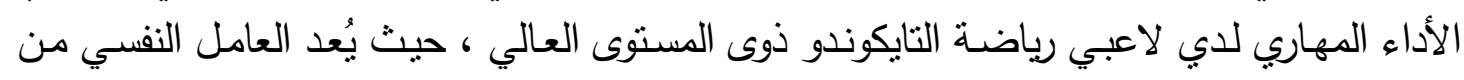

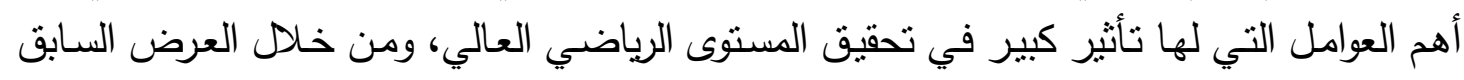

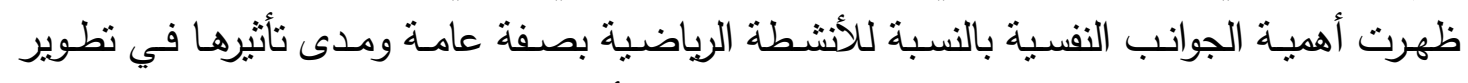

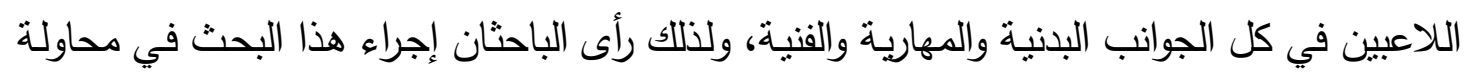

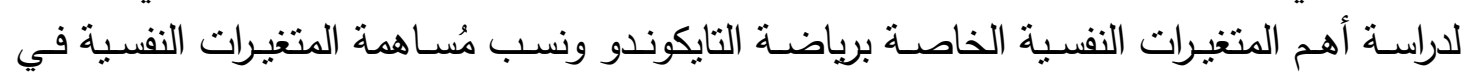

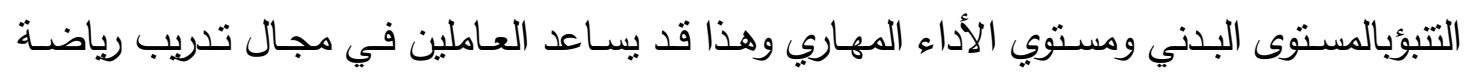

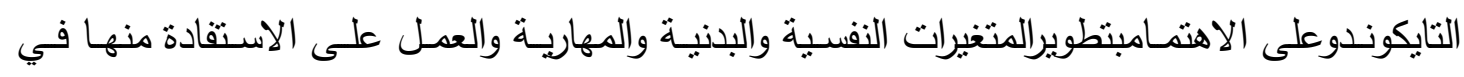
تطوير الجانب التتافسي للاعبي المستويات العليا.

$$
\text { هرف البحثث: إلى التعرف على: }
$$

1- بعضالمتغيرات النفسية المساهمة في تحديد مستوى أداء لاعبي التايكوندو ذوبي المستويات العليا.

r- التعرف على استمارة تقييم مستوى أداء لاعبي التنايكوندو ذوي المستويات العليا.

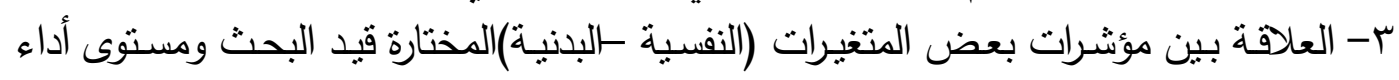
لاعبي التايكوندوذوي المستويات العليا.

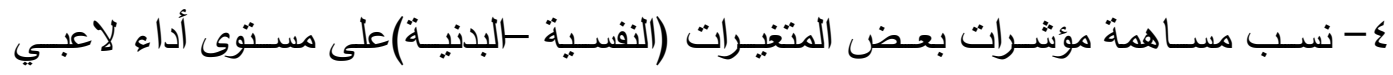
التايكوندو ذوي المستويات العليا.

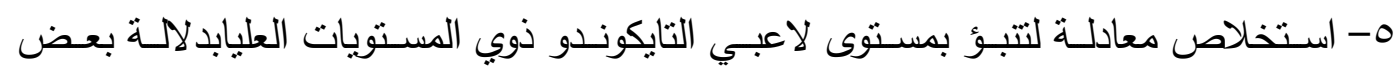

$$
\text { فروض البحث: المتغرات (النفسية - البدنية) المختارة. }
$$

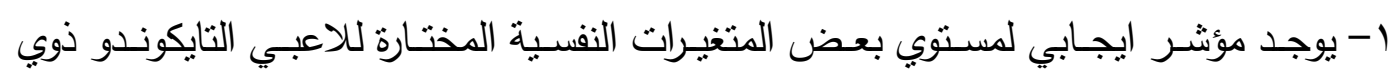
المستويات العليا عينة البحث. r-يوجد مؤشر ايجابي لنقيبم مسنوى الأداء المهاري للاعبي التايكوندو ذوبي المستويات العليا عينة البحث.

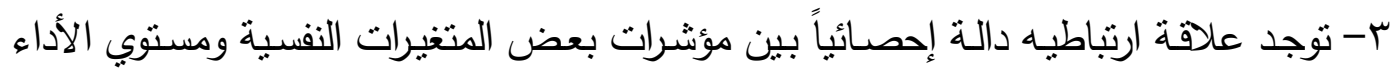

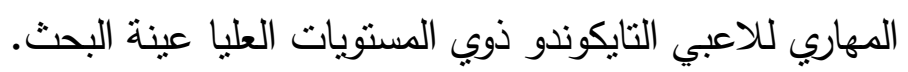

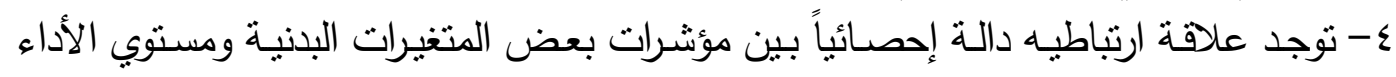
المهاري للاعبي التايكوندو ذوي المستويات العليا عينة البحث. 


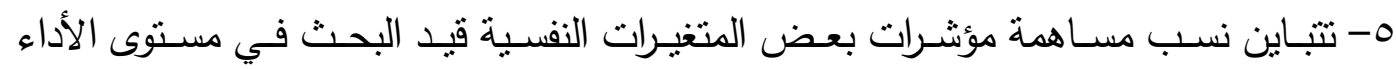
المهاري للاعبي التايكوندو ذوي المستويات العليا عينة البحث.

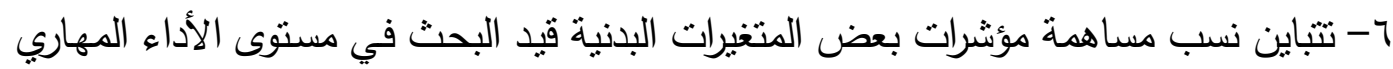
للاعبي التايكوندو ذوي المستويات العليا عينة البحث.

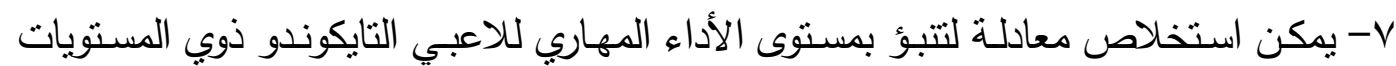
العليا بدلالة بعض المتغيرات النفسية قيد البحث.

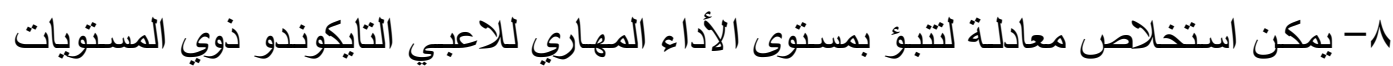

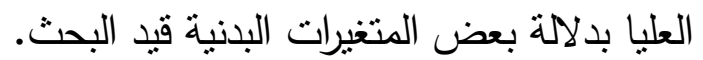

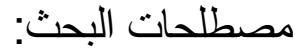
- القلق: هو حالة انفعالية مزمنة تصاحبها اضطرابات عصبية وعقلية، وتتسم بالخوف والثنعور

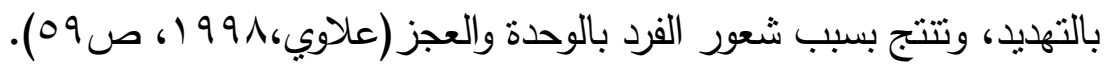

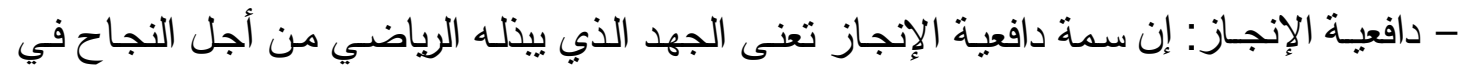

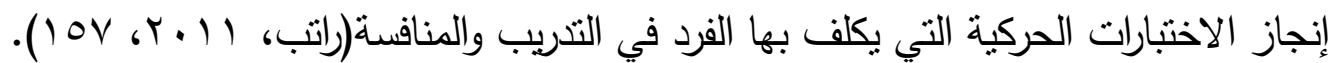

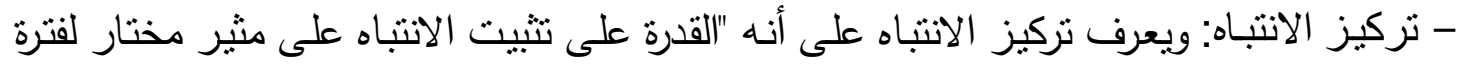

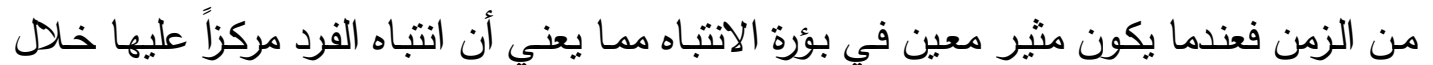

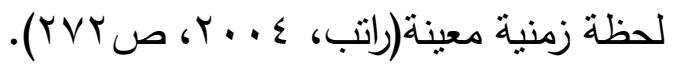
أولاً: منهج البحث:

استخدم الباحثان المنهج الوصفي، بالأسلوب المسحي كأحد أنماطه وذللك لملاعمنه لطبيعة البحث وأهدافه.

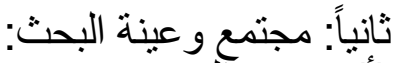

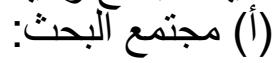

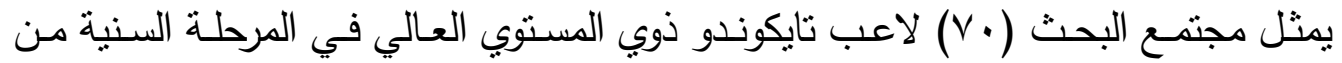

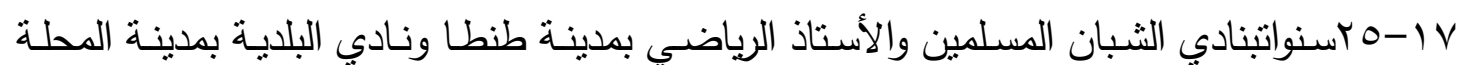

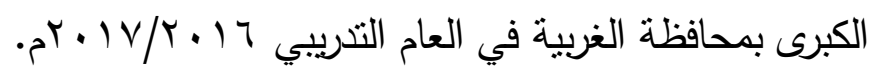

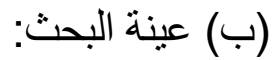

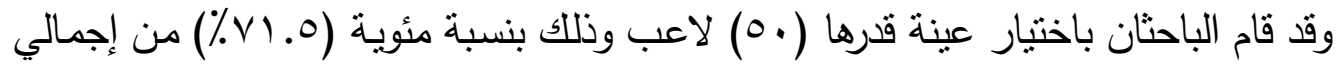

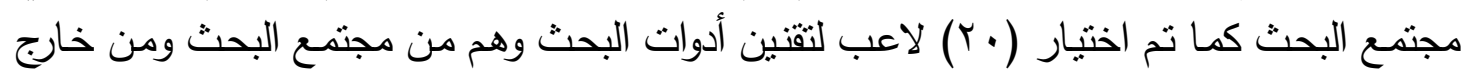

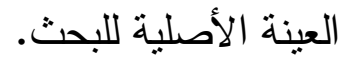




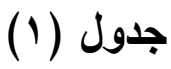

حجم العينة ونسبتها إلى المجتمع الأصلي

\begin{tabular}{|c|c|c|c|}
\hline النسبة المئوية & عدد اللاعبين & البيان & 5 \\
\hline$\%$ \%^.० & $r$. & عينة الدراسة الاسنطلاعية & 1 \\
\hline$\% \vee 1.0$ & 0 . & عينة الدراسة الأساسية & $r$ \\
\hline$\%$ & $V$. & إجمالي & \\
\hline
\end{tabular}

شروط اختيار العينة:

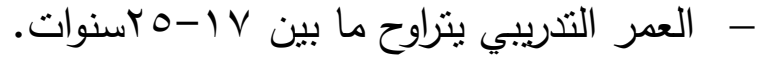

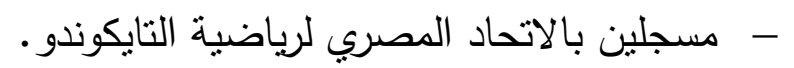

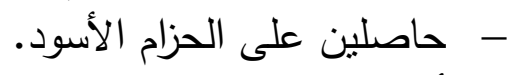

- - أن يكون اللاعبين حاصل على الاصود بطولات جمهورية او دولية.

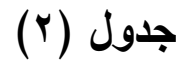

الدلالات الإحصائية لتوصيف إفراد عينة البحث في المتفيرات قيد البحث لبيان اعتدالية البيانات

$0 .=\dot{0}$

\begin{tabular}{|c|c|c|c|c|c|c|c|}
\hline الالتواء & التفلطح & انحراف & الوسيط & الحسابي & وحدة القياس & المتغيرات & 5 \\
\hline & & & & & & \multicolumn{2}{|c|}{ أ معدلات دلالات النمو } \\
\hline .491 & $1 . \leqslant \leqslant r-$ & •.ATE & rI... & $r \cdot . \wedge r$ & سنة/شهر & |العمر الزمني & 1 \\
\hline $.0 \leq 7$ & . ITY & r.VIT & IVY.0.. & IVY.AIT & سم & |الطول & r \\
\hline.$\vee V 71$ & $\ldots r$ & $\varepsilon . r \cdot 1$ & $v 1.0 \ldots$ & VT.MIT & كجم & |الوزن & $r$ \\
\hline \multirow[t]{2}{*}{$. .0 \cdot \mathrm{V}-$} & $. \vee V T O-$ & .977 & $9.0 \ldots$ & $9 . \ldots$ & سنة/شهر & |العمر التدربيبي & $\varepsilon$ \\
\hline & & & & & & مقياس المتغيرات النفسية & ب \\
\hline$\cdot r \ldots-$ & $\because V Y I$ & $.0 \ldots$ & $1.0 \ldots$ & $1 . \leqslant 0$. & درجة & |القلق الرياضي & 11 \\
\hline$. .1 \wedge \varepsilon-$ & ..乞।^- &..$\leqslant 9$. & r.0.. & T. $\Sigma V$. & درجة & لدافعية الانجاز & $r$ \\
\hline . . Y १- & $. .017-$ & .07. & r.o.. & T.EY. & درجة & تركيز الانتباه & $r$ \\
\hline \multirow[t]{2}{*}{.040} & $\because \leqslant Y \wedge-$ & . .Tז & r.... & r.נIT & درجة & المتوسط العام للمقياس & - \\
\hline & & & & & & |لاختبارات البدنية & ج \\
\hline$\cdot r \leq \Lambda-$ & $1.1 \leq \wedge-$ & $.1 \leq$. & r.ro. & T.Mr. & 5 & الوثب العرض من الثبات & 1 \\
\hline $1 . r Y \varepsilon$ & r.l Yo & $\because \leqslant 11$ & $\varepsilon . Y \wedge 0$ & $\varepsilon . \varepsilon \ldots$ & $ث$ & عدو · r متر بداية متحركة & r \\
\hline $.0 \mathrm{VV}-$ & 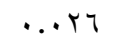 & $v . .09$ & $v 1.0 \ldots$ & $v 1.0 \ldots$ & $\stackrel{H}{H}$ & الوقوف على عرضة بمشط القدم & $r$ \\
\hline 1.1 .0 & $1 . r \wedge \varepsilon$ & $\cdot . \wedge r V$ & 7.90 & $\vee .17$. & 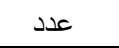 & |الوثبة الرباعية & $\varepsilon$ \\
\hline$. .10 \leq$ & $1 . \Lambda \cdot r-$ & E.rTV & $r \leq .90$. & ro.1r. & 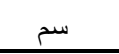 & مرونة مفصل الحوض & 0 \\
\hline$. . I Y Y-$ & - & 1.891 & r... & Y1.0. & درجة & مستوى الاداء & د \\
\hline
\end{tabular}

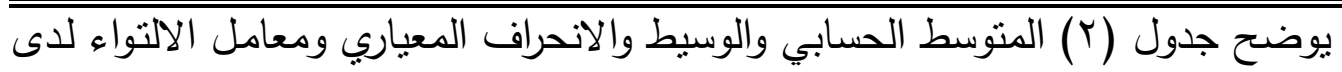

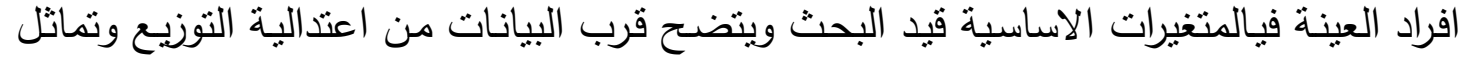

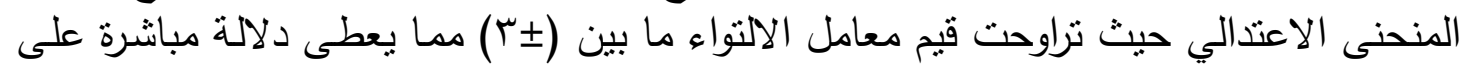
خلو البيانات من عيوب التوزيعات الغير اعتدالية.

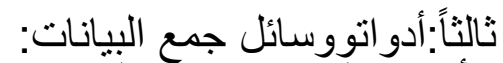
الأجهزة المستخدمة في القياس:

- كارنية الاتحاد المصري لتايكوندو لتحديد العمر الزمنى والتدريبي لعينة البحث. 
- - - رستاميتز لقياس الطول الكلي للاعبين.

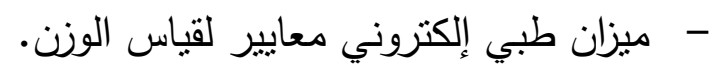

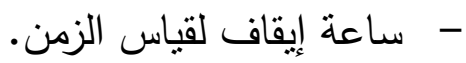

- - - - مسادة لكم (شاخص).

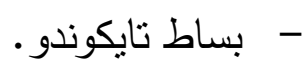

- - - - علامات ارشادية لاصنة.

- كاميرا تصوير فيديو ديجنال بحامل ثنالثي لتصوير مستوي الأداء المهاري. - فلاش ميوموري لتحميل فيديو تصوير مستوي الأداء المهاري عليها ونيا وتقديمة للمحكمين.

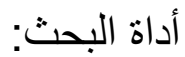

- مقياس المتغيرات النفسية للاعبي التايكوندو ذوي المستوى العالي. (إعداد الباحثان). - - - اختبارات المتغيرات البدنية. - - استمارة تقييم مستوي الأداء المهاري. (إعداد الباحثان).

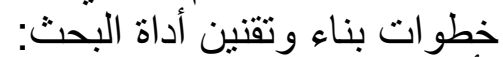

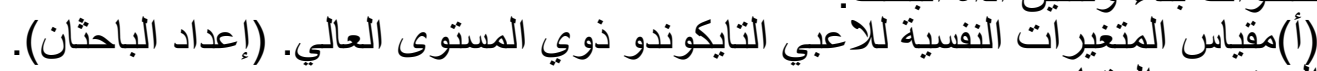
الهدف من المقياس: التعرف على المتغيرات النفسية للاعبي التايكوندو ذوي المستوى العالي.

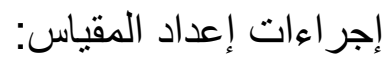
قام الباحثان بإعداد المقياس وفقاً للخطوات الباد التالية:

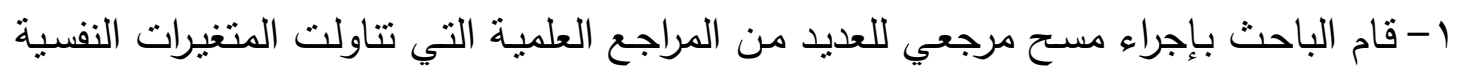

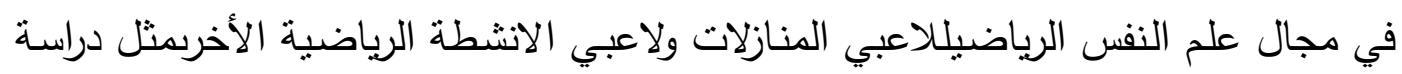

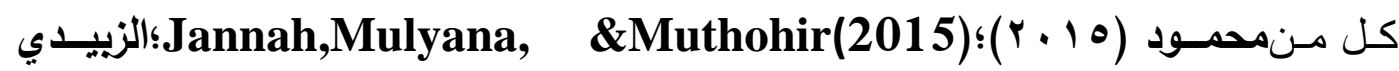

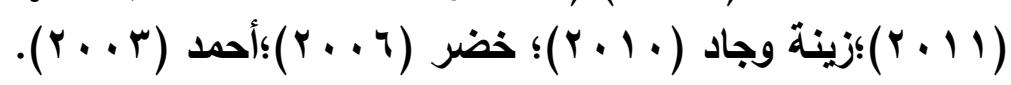

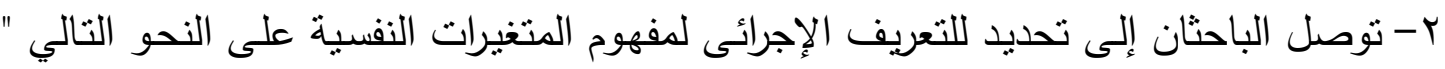

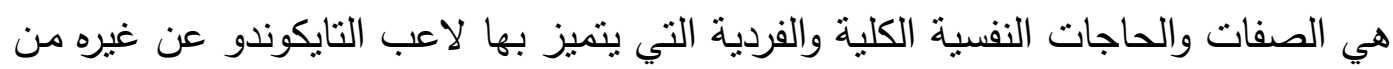

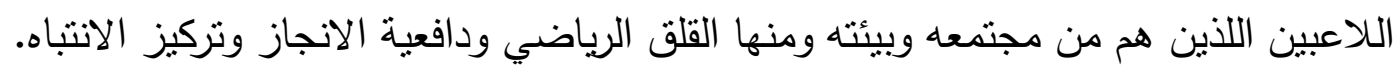

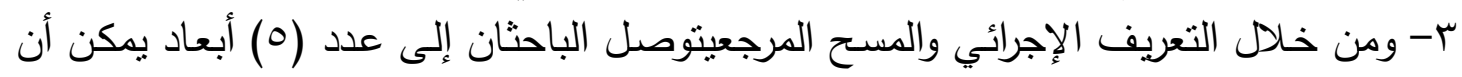
تمثل أبعاد رئيسية لمقياس المتيفيرات الإنيات النفسية.

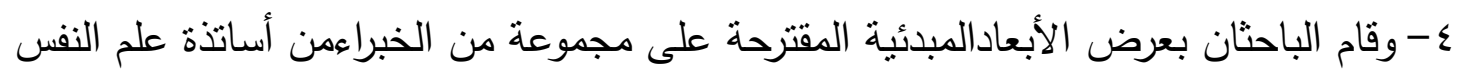

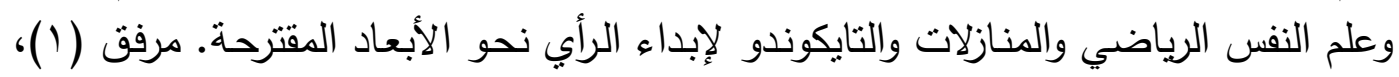

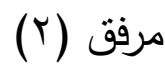
قام الباحثان بإجراء المعاملات العلمية لمقياس المتغيرات النفسية لعينة البحث وذلك على

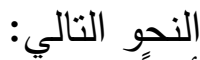
أو لاً: صدق المقال: المقياس 1- الودق المحتوى (الصدق الظاهري):

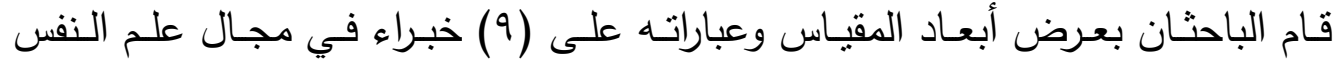

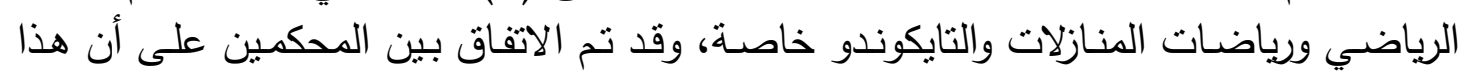




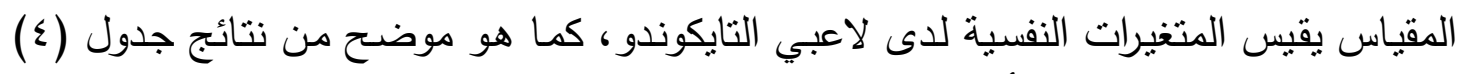

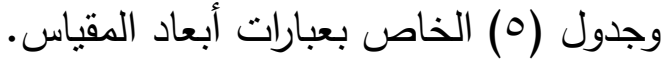

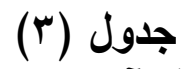

التكرار والنسبة المئوية والأهمية النسبية لآراء السادة الخبراء حول أبعاد مقياس المتفيرات

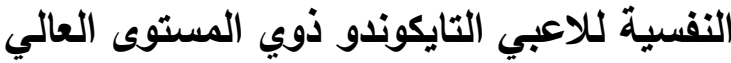

$q=\dot{0}$

\begin{tabular}{|c|c|c|c|c|c|c|c|}
\hline \multirow{2}{*}{ الأهمية النسبية } & \multirow[b]{2}{*}{ الوزن النسبي } & \multicolumn{2}{|c|}{ لا أوافق } & \multicolumn{2}{|c|}{ أوافق } & \multirow{2}{*}{ الأبعاد } & \multirow[b]{2}{*}{5} \\
\hline & & $\%$ & 5 & $\%$ & ك & & \\
\hline$\overline{1} \ldots \ldots$ & 9 & $\cdots$ & - & $\overline{1 \ldots \ldots}$ & 9 & القلق الرياضي & 1 \\
\hline $1 \ldots$. & 9 & $\cdots$ & . & $1 \ldots \ldots$ & 9 & دافعية الإنجاز & r \\
\hline$\varepsilon \varepsilon . \varepsilon \varepsilon$ & $\varepsilon$ & 00.07 & 0 & $\varepsilon \varepsilon . \varepsilon \varepsilon$ & $\varepsilon$ & الشجاعة & $r$ \\
\hline $1 \ldots \ldots$ & 9 & $\cdots$ & $\cdot$ & $1 \ldots \ldots$ & 9 & تركيز الانتنباه & $\varepsilon$ \\
\hline$\varepsilon \varepsilon . \varepsilon \varepsilon$ & $\varepsilon$ & 00.07 & 0 & $\varepsilon \varepsilon . \varepsilon \varepsilon$ & $\varepsilon$ & الجرأة & 0 \\
\hline
\end{tabular}

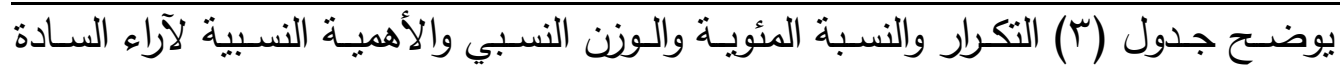

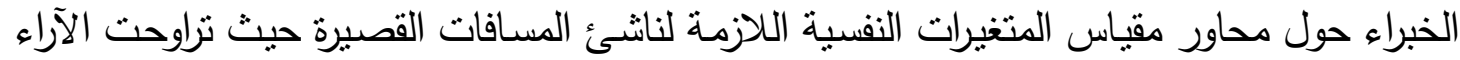

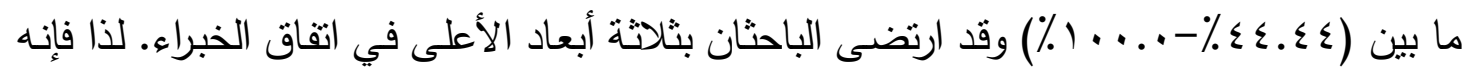

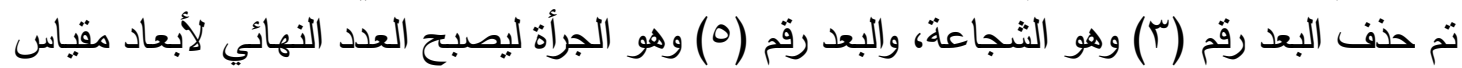

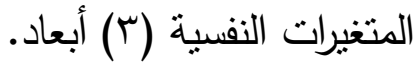

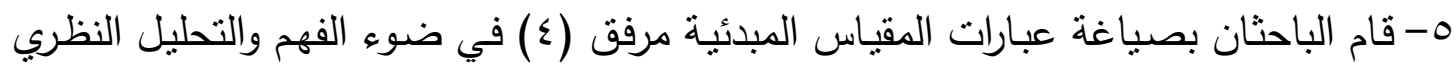

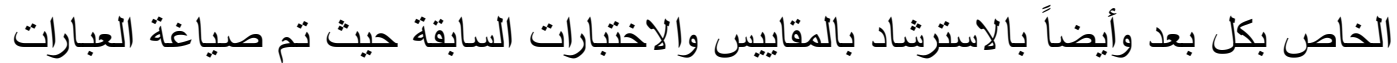

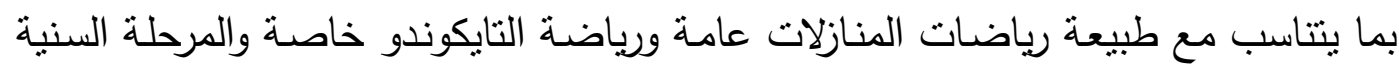

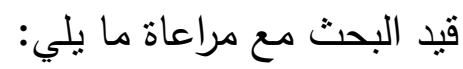
- - أن تكون العبارات سهلة وواضحة.

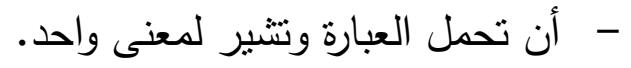
- - أن تكون مناسبة للهوف المراد قياسه.

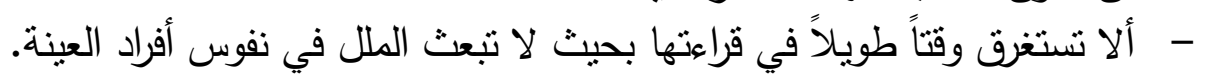




\section{جدول (§)}

النسبة المئوية لآراء السادة الخبراء حول عبارات مقياس المتغيرات النفسية للاعبي التايكوندو ذوي المستوى اعلى العالي مولي

$q=\dot{0}$

\begin{tabular}{|c|c|c|c|c|c|}
\hline \multicolumn{2}{|c|}{ البعد الثالثتركيز الانتباه } & \multicolumn{2}{|c|}{ البعد الثانيدافعية الانجاز } & \multicolumn{2}{|c|}{ البعد الأول القلق الرياضي } \\
\hline نسبة الموافقة\% & 5 & نسبة الموافقة. & 5 & نسبة الموافقةٌ٪ & 5 \\
\hline$\overline{1 \cdots \cdots}$ & 1 & 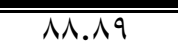 & $\overline{1}$ & $1 \cdots$ & $\overline{11}$ \\
\hline$\wedge \wedge . \wedge 9$ & T & $\ldots \ldots$ & $r$ & $\wedge \wedge . \wedge 9$ & r \\
\hline$\cdots \cdots$ & $\mu$ & $\varepsilon \varepsilon . \xi \varepsilon$ & $r$ & $1 \ldots$ & $r$ \\
\hline $1 \ldots$ & $\varepsilon$ & VV.VA & $\varepsilon$ & $\wedge \wedge . \wedge 9$ & $\varepsilon$ \\
\hline $77.7 \mathrm{~V}$ & 0 & $\cdots \ldots$ & 0 & $\wedge \wedge . \wedge 9$ & 0 \\
\hline$\cdots \cdots$ & 7 & $\wedge \wedge . \wedge 9$ & 7 & 00.07 & 7 \\
\hline $1 \ldots$ & V & חיז. & V & $\wedge \wedge . \wedge 9$ & V \\
\hline$\varepsilon \varepsilon . \varepsilon \leqslant$ & $\Lambda$ & $\checkmark V . \vee \wedge$ & $\Lambda$ & $\cdots \cdots$ & $\wedge$ \\
\hline$\cdots \cdots$ & 9 & $\cdots \ldots$ & 9 & $\cdots \cdots$ & 9 \\
\hline$\wedge \wedge . \wedge 9$ & $1 \cdot$ & $\cdots \cdots$ & 1. & $\wedge \wedge . \wedge 9$ & $1 \cdot$ \\
\hline $1 \cdots$ & 11 & $\wedge \wedge . \wedge 9$ & 11 & $1 \ldots$ & 11 \\
\hline$\cdots \cdots$ & Tr & $\vee \vee . \vee \wedge$ & TY & 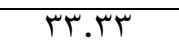 & Tr \\
\hline \multirow[t]{4}{*}{$\checkmark \vee . \vee \wedge$} & $\pi$ & $\wedge \wedge . \wedge 9$ & $1 \pi$ & $1 \ldots$ & $1 \pi$ \\
\hline & & $\vee \vee . \vee \wedge$ & $1 \varepsilon$ & $77.7 V$ & $1 \varepsilon$ \\
\hline & & $\wedge \wedge . \wedge 9$ & 10 & $\wedge \wedge . \wedge 9$ & 10 \\
\hline & & & & $1 \ldots$ & 17 \\
\hline
\end{tabular}

يوضـح جـدول (ع)النسـبة المئويـة لآراء السـادة الخبـراء حـول عبـارات مقيـاس الآثـار

المتغيرات النفسية اللازمة لناشئ المسافات القصيرة ويتضح تراوح النسبة المئوية للعبارات مابين

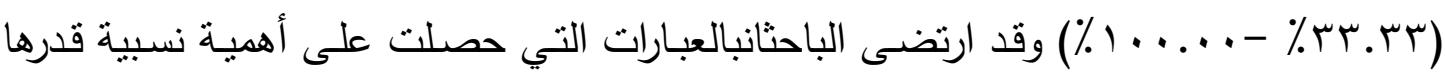

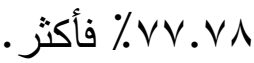

جدول (0)

العدد المبئي والنهائي وأرقام العبارات المستبعدة لمقياس المتغيرات النفسية قيد البحث $q=\dot{0}$

\begin{tabular}{|c|c|c|c|c|c|c|c|}
\hline العهائي & أرقام العبارات & عدد العبارات & أرقام العبارات & عدد العبارات & العدد المبدئي & الابعاد & م \\
\hline$\pi$ & - & - & $1 \varepsilon-1 Y-7$ & r & 17 & القلق الرياضي & 1 \\
\hline$\pi$ & 1 & 1 & $v-r$ & r & 10 & دافعية الانجاز & r \\
\hline 11 & $9-\varepsilon$ & r & $1-0$ & r & $\pi$ & تركيز الانتباه & r \\
\hline rv & r & r & V & V & $\leqslant \varepsilon$ & الإجمالي & - \\
\hline
\end{tabular}

يوضـح جدول (0) العدد المبدئي والنهائي وأرقام العبارات المستبعدة لمقياس المتغيرات

النفسية قيد البحث وبتضـح ان العدد المبدئي للمقياس (ع ع) عبارة وبعد العرض على السـادة الخبراء قام الباحثان بحذف عدد (V) عبارة، ليصبح إجمالي عدد العبارات (rV) عبارة مع تعديل (r) عبارات وبدون أي اضافة (صدق المحكمين). 
ب-صدق الاتساق الا(خلي للمقياس:

قام الباحث بحساب معامل صدق الاتساق الداخلي لمقياس المتغيرات النفسيثيوم الاثثين

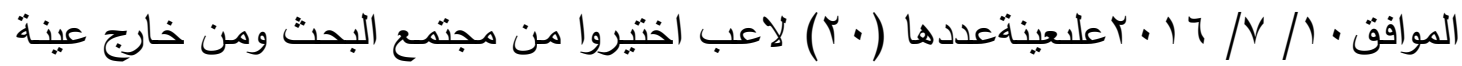

البحث الأساسية وجدول (T)، (V) يوضح معامل صدق الاتساق الداخلي للمقياسوكما يأتي:

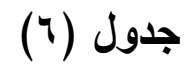

صدق الاتساق الداخلي بين العبارة والبعد ويين العبارة

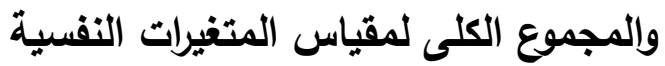

$r \cdot=\dot{0}$

\begin{tabular}{|c|c|c|c|c|c|c|c|c|}
\hline \multicolumn{3}{|c|}{ البعد الثالث تركيز الانتباه } & \multicolumn{3}{|c|}{ البعد الثاني دافعية الانجاز } & \multicolumn{3}{|c|}{ البعد الاول القلق الرياضي } \\
\hline مع المجموع العبارة & مع البعد & 5 & مع المجموع & مع البعد & 5 & مع المجموع & مع البعد العبارة & 3 \\
\hline.$\wedge 7$ & .99 & 1 & .110 &..$\wedge 9$ & 1 & ..AY & .99 & 1 \\
\hline.$\wedge \Sigma$ &.$\wedge \vee$ & $r$ & .9. & $\cdot . \wedge \wedge$ & $r$ & .99 & $\cdot . \wedge \varepsilon$ & $r$ \\
\hline .9. &.$\wedge \mathrm{T}$ & $\Gamma$ &. .91 & $\cdot . \wedge \varepsilon$ & $r$ &. .19 & . .AT & $\mu$ \\
\hline.$\wedge \wedge$ & . . & $\varepsilon$ &..$\wedge V$ & . .Ar & $\varepsilon$ & .99 &.$\wedge 0$ & $\varepsilon$ \\
\hline..$\wedge 7$ & .991 & 0 &. .19 &..$\wedge \wedge$ & 0 &..$\vee \wedge$ &. .9 & 0 \\
\hline..$\wedge I$ &. .10 & 7 & .94 &. .19 & 7 &.$v q$ &..$\wedge \wedge$ & 7 \\
\hline. .91 &.$\wedge \vee$ & V &..$\wedge 9$ & $\cdot . \wedge$. & V &..$\wedge 9$ & . . & V \\
\hline.$\wedge \wedge$ &..$\wedge r$ & $\Lambda$ & $\cdot . \wedge r$ & .991 & $\Lambda$ &. .19 &.$\wedge$. & $\Lambda$ \\
\hline .9. & $\cdot . \wedge \varepsilon$ & 9 &..$\wedge 9$ & .9 . & 9 & $\cdot . \wedge \varepsilon$ &. .19 & 9 \\
\hline . .Ar & $\cdot . \wedge \wedge$ & 1. &. .91 & $\cdot . \wedge \wedge$ & 1. &.$v 1$ &.$V V$ & 1. \\
\hline \multirow[t]{3}{*}{. .19} & . . & 11 &..$\wedge r$ &. .91 & 11 &..$\wedge 9$ &.$\wedge \varepsilon$ & 11 \\
\hline & & & .99 &..$\wedge \mathrm{V}$ & IT &.$\wedge 7$ & .9 & $1 T$ \\
\hline & & &.$\wedge 7$ &. $.9 r$ & $1 T$ &. .91 &.$\wedge \wedge$ & 11 \\
\hline
\end{tabular}

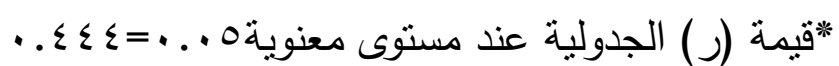

يوضح جدول (آ) وجود ارتباط ذو دلالة إحصائية بين العبارة والبعد حيث تراوحت قيمة

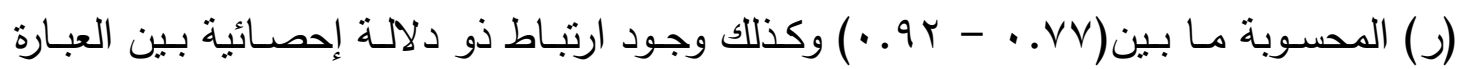

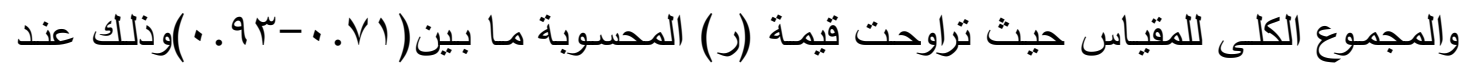
مستوى معنوية ه...، مما يشير إلى صدق الاتساق الداخلي للمقياس قيد البحث. 


\section{جدول (v)}

صدق الاتساق الااخلي بين البعد والمجموع الكلى لمقياس المتغيرات النفسية

$r \cdot=\dot{U}$

\begin{tabular}{|c|c|c|}
\hline معامل الارتباط & ابعاد المقياس & 5 \\
\hline$\star \star . . \wedge 9$. & القلق الرياضي & 1 \\
\hline$\star \star . .91 \leq$ & دافعية الانجاز & r \\
\hline$\star \star \cdot .9 . \varepsilon$ & تركيز الانتباه & $r$ \\
\hline
\end{tabular}

** دال إحصائيا عند مستوى (1 . . *) * دال إحصائيا عند مستوى (0. . .

يوضح جدول (V)وجود ارتباط ذو دلالة إحصائية بين مجموع البعد وبين المجموع الكلى

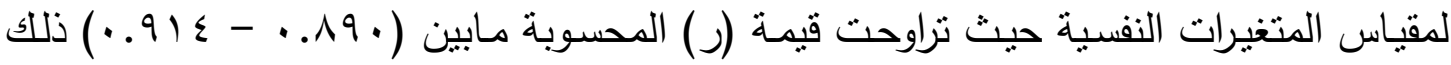
عند مستوى معنوية 0... ..

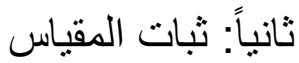

قام الباحثان بحسـاب معامل الثبات لمقياس المتغيرات النفسية قيد البحثعن طريق تطبيق

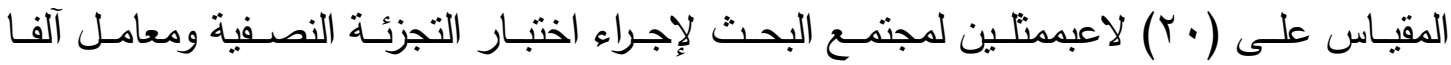

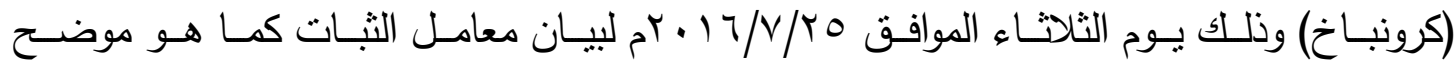

بجدول(^).

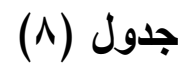

التجزئة النصفية ومعامل الفا لبيان معامل الثبات لمقياس المتغيرات النفسية

$r_{0}=\dot{U}$

\begin{tabular}{|c|c|c|c|c|}
\hline معامل الفا & \multicolumn{2}{|c|}{ اختبار التجزئة النصفية } & \multirow[b]{2}{*}{ ابعاد المقياس } & \multirow[b]{2}{*}{ r } \\
\hline معامل الفا للبعد عند حذف درجة العبارة من الارجة & جنمان & سبيرمان -براون & & \\
\hline$\cdot . \wedge V T$ &.$\wedge 71$ & $\cdot . \wedge \varepsilon r$ & القلق الرياضي & 1 \\
\hline .1179 & $\cdot . \wedge \vee 1$ &.$\wedge \circ \mathrm{V}$ & دافعية الانجاز & r \\
\hline.$\wedge \vee 0$ & . . & $\because v \leqslant q$ & تركيز الانتباه & 9 \\
\hline.$\wedge V \vee$ &.$\wedge V T$ & י & الارجة الكلية & \\
\hline
\end{tabular}

يوضـح جدول (^) اختبـار التجزئـة النصـفية بطريقتيسيبرمان - بـراون وجتمـان وكذلك

معامـل الفـا (كرونبـاخ) لبيـان معامـل الثبـات لأبعـاد البحـث الثلاثثة لمقيـاس المتغيـرات النفسية

بالإضافة الى إجمالي المقياس ويتضح وجود دلالات احصائية قوية تثير الى ثبات المقياس.

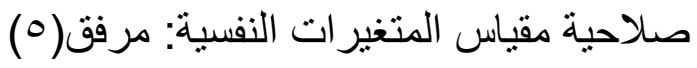


وفى ضوء صلاحية مقياس المتغيرات النفسيةلاعبي التايكوندو عينة البحث تم وضعه

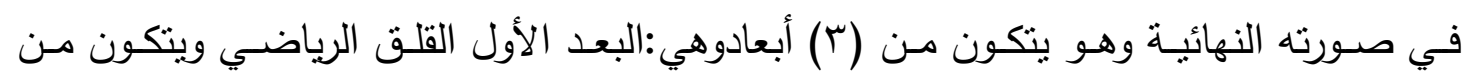

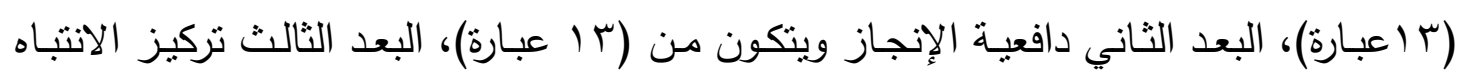

$$
\text { ويتكون من(1) - (1) عبارة). }
$$

يتم استجابة المفحوصين على المقياس من خلاد ثلاث استجابات وفقاً لميزان تقديري ثلاثي

$$
\begin{aligned}
& \text { على التوالي بدرجات (دائما (Y)- أحيانا (Y) - نادرا ( ()). } \\
& \text { (ب) المعاملات العلمية للاختبار ات البات البدنية. } \\
& \text { الهدف من الاختبار ات البدنية: }
\end{aligned}
$$

التعرف من خلال الاختبارات البدنية لنتغيرات(بك نتشاجي - نى نتاجي - نارا تثاجي)

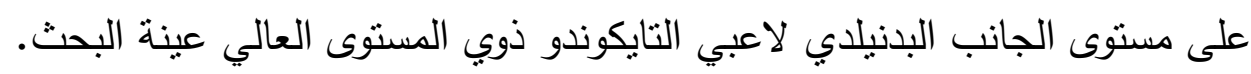

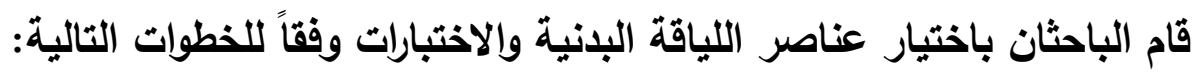

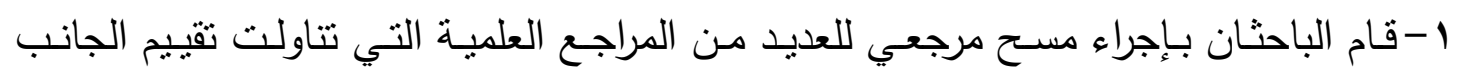

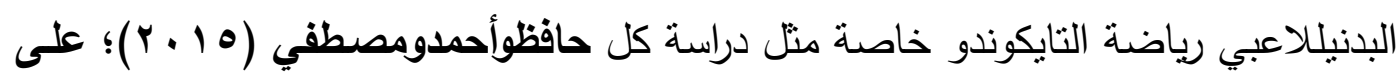

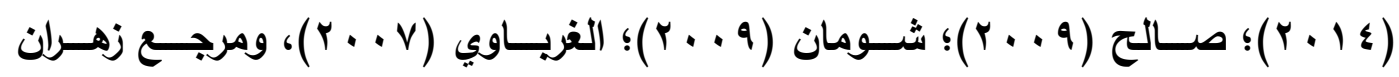

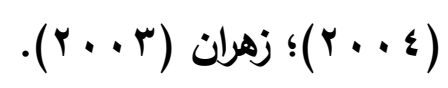

r- وقام الباحثان بعرض استمارة استطلاع رأى الخبراء في الاختبارات البننية على مجموعة من الخبراء

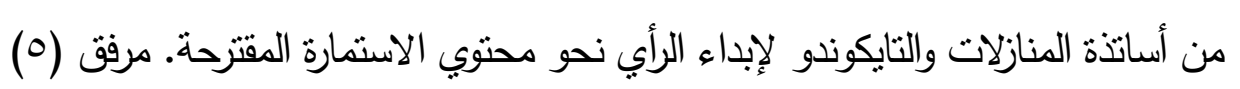
1 - 1 المساب صدق الاختبار ات البدنية: صدق المحتوي (الصدق الظاهري) قـام الباحثنان بعرض مجموعـة مـن الاختبـارات البدنيـة على ( • ( ) خبراء في مجـال

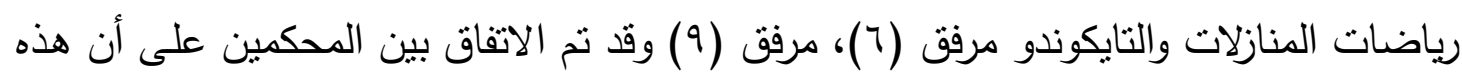

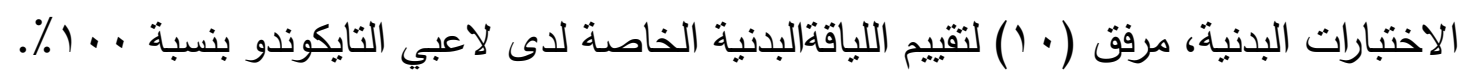

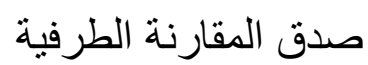

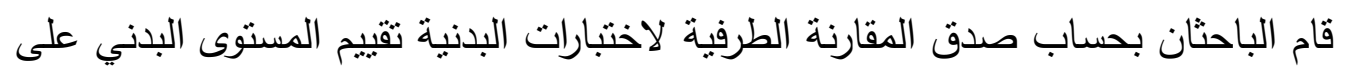

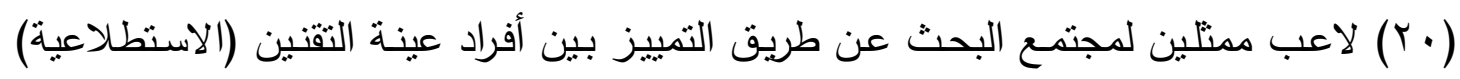

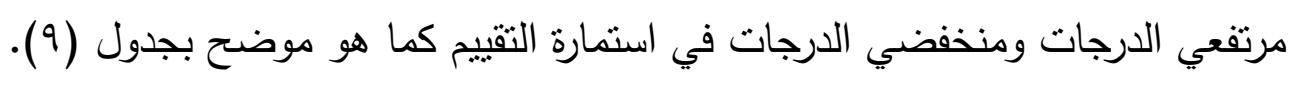




\section{جدول (9)}

\section{دلالة الفروق بين متوسطي الارياعى الأعلى والارياعى الأدنى} لكلاختبارات البدنية لبيان معامل الصدق الاعلى لالاعياع

$r \cdot=\dot{0}$

\begin{tabular}{|c|c|c|c|c|c|c|c|c|}
\hline \multirow{2}{*}{ الصدق معل } & \multirow{2}{*}{ 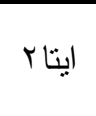 } & \multirow{2}{*}{ تيمة } & \multirow{2}{*}{ المتوسطات } & \multicolumn{2}{|c|}{ الارباعى الادنى ن=0 } & \multicolumn{2}{|c|}{ الارباعى الأعلن= } & \multirow{2}{*}{ الاختبارات البدنية } \\
\hline & & & & $\varepsilon \pm$ & س & $\varepsilon^{ \pm}$ & س & \\
\hline $.9 \cdots$ & $\cdot . \wedge 1$. & $0 . \wedge \leq T$ & .0 .1 & $\ldots 0$ & $1 . \wedge \vee 0$ & $\cdot r \cdot \Sigma$ & 广.r人T & |الوثب العرض من الثبات \\
\hline$\cdot . \wedge \wedge \vee$ & $\cdot . \vee \wedge \vee$ & $0 . \varepsilon r V$ & .940 & $\cdot . \wedge r q$ & 7.r... &. . TTr & E.MYO & | |عدو ·r متر بداية متحركة \\
\hline. $.9 \Gamma \wedge$ & $\cdot \wedge \wedge$. & $\mathrm{V} .7 \mathrm{VV}$ & $17.0 \wedge \pi$ & $1.0 \ldots$ & 09.10. & $\varepsilon . \cdot V \cdot$ & VO.ATr & | الوقوف على عرضة بمشط القدم \\
\hline $.9 r T$ & $\cdot . \wedge 0 Y$ & 7. $\vee \wedge \wedge$ & $1.9 \times 0$ & - & $0.7 Y 0$ & $\cdot .1 \times q$ & V.7.. & كألوثبة الرباعية \\
\hline .1190 & $\cdot A \cdot 1$ & $0.7 \wedge Y$ & V.r人T & $\cdot V \cdot r$ & $r . . V \ldots$ & r.. Tร & r^.・Ar & ك|مرونة مفصل الحوض \\
\hline
\end{tabular}

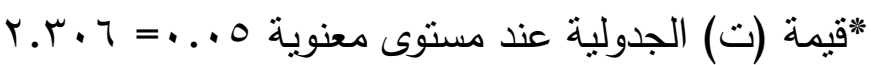

يتضـح من جدول(9) وجود فروق ذات دلالة احصـائية عند مستوى معنوية ه م. . ببين

متوسطيالارباعى الأعلى والارباعى الأدنى لدى عينة التقنين للاختبارات البدنية قيد البحث، كما يتضح حصول الاختبارات على قوة تأثثر وصدق عالية. r - حساب ثبات استمارة التقبيم

قام الباحثان بحساب معامل الثبات للاختبارات البدنيـةلتقييم المستوى البدني عن طريق تطبيق المقياس على (·r) لاعب ممنلين لمجتمع البحث وإعادة تطبيقه مرة أخري يوم التثلاثاء

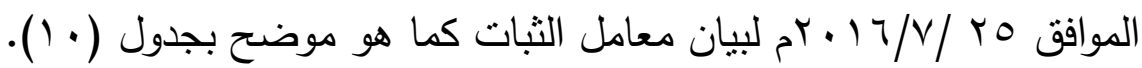
جدول (1.)

معامل الارتباط بين التطبيق واعادة التطبيق للاختبارات البذنية لبيان معامل الثبات $r_{0}=\dot{0}$

\begin{tabular}{|c|c|c|c|c|c|c|}
\hline \multirow{2}{*}{ معامل الارتباط } & \multicolumn{2}{|c|}{ إعادة النطبيق } & \multicolumn{2}{|c|}{ 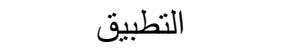 } & \multirow{2}{*}{ الاختبارات البدنية } & \multirow{2}{*}{ r } \\
\hline & $\varepsilon \pm$ & س س & $\varepsilon \pm$ & س & & \\
\hline. .941 & . & T.וT & 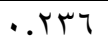 & $r .1 Y q$ & |الوثب العرض من الثبات & 1 \\
\hline .910 &. . & 0.791 &..$\varepsilon r V$ & $0 . v \cdot 1$ & عدو ·r متر بداية متحركة & r \\
\hline$\cdot .19 \varepsilon$ & T.ETV & TA.IT. & $\varepsilon . \vee 0 \varepsilon$ & $7 V .0 \leq Y$ & الوقوف على عرضة بمشط القدم & r \\
\hline$\cdot .9 \cdot V$ &.$\vee \wedge \wedge$ & 7.VVT & .904 & $7 . \vee 1 K$ & |الوثبة الرباعية & $\varepsilon$ \\
\hline$\cdot . \wedge 99$ & Y.AYI & rะ.r人q & r.M.To & rE.rqT & مرونة مفصل الحوض & 0 \\
\hline
\end{tabular}

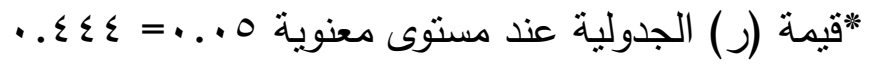

يوضح جدول(· (1) وجود ارتباط ذو دلالة احصائية بين التطبيق واعادة التطبيق (إعادة تطبيق الاختبار) للاختبارات البدنية لاى عينة التقنين عند مستوى معنوية ه ... ، مما يشير الى ثبات الاختبارات. (ج) المعاملات العلمية لاستمارة تقييم مستوي الأداءالمهاري. (إعداد الباحثان). 


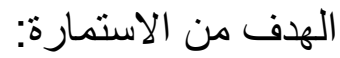

التعرف من خلالاستمارة تقيم أداء مهارة (بك تثـاجي - نسى تثـاجي - نـارا تتـاجي)

الأكثر استخداما في المباريات على مستوى الاداء للاعبي التايكوندو ذوب المستوى العالي عينة

$$
\text { خطوات إعداد الاستمارة: }
$$

قام الباحثان بإعداد الاستمارة وفقاً للخطوات التالية:

ب-قام الباحثان بإجراء مسح مرجعي للعديد من المراجع العلمية التي تتاولت تقييم الاداءلاعبي

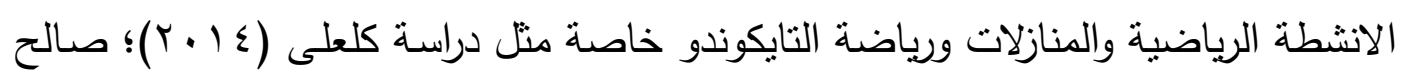

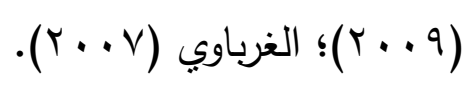

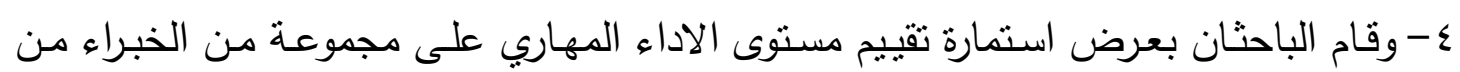

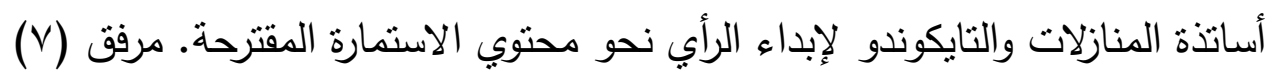

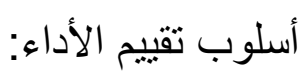

0-سوف يتم تقيم الاداء خـلال تصوير الاداء المهاري وتحكيمها من قبل الحكام المسجلين

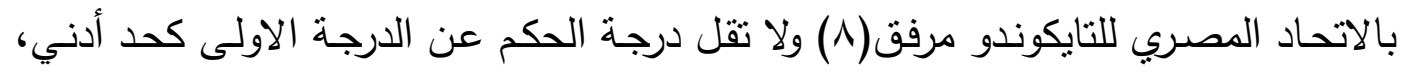

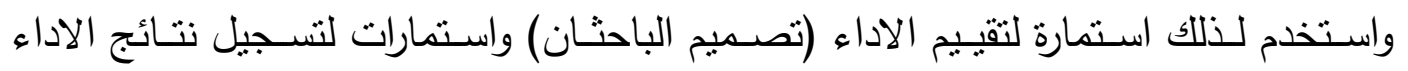

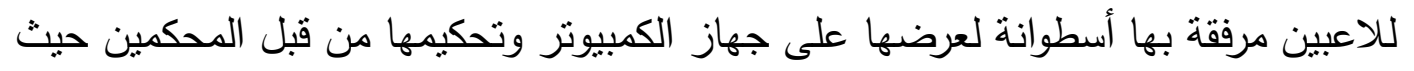
يمنح اللاعب درجة من كل حكم على حده ثم يتم تجميع درجات الحكام الثلاثة واخذ الدرجة فئل

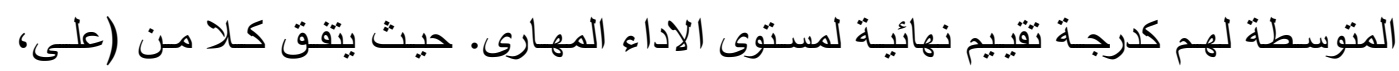

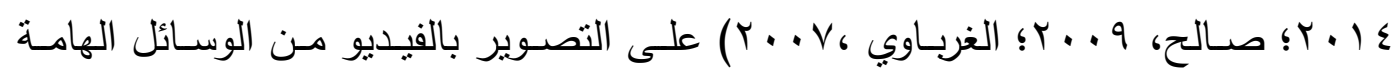

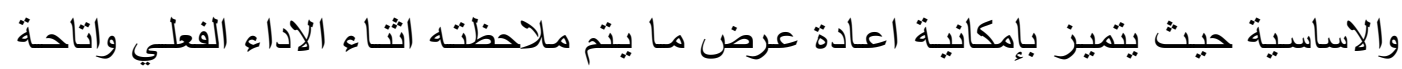

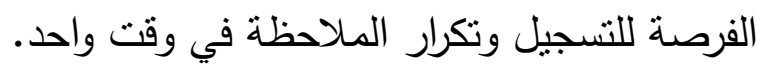

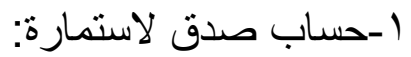

صدق المحتوي (الصدق الظاهري) لإنمارة

قام الباحثان بعرض استمارة تقييم مستوى الاداء على (· · ( ) خبراء في مجال رياضات المنازلات والتايكوندو مرفق (0)، وقد تم الاتفاق بين المحكمين على أن هذه الاستمارة مناسبة

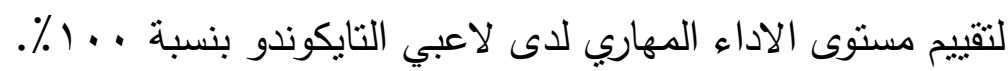

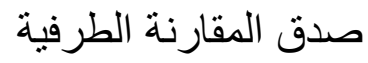


قام الباحثان بحسـاب صدق المقارنة الطرفية لاستمارة تقيهم مستوى الاداء قيد البحث

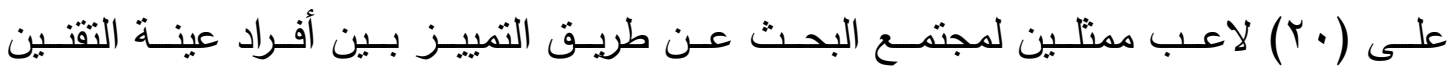

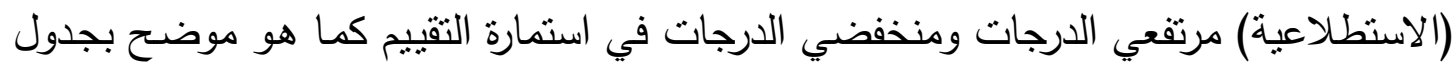

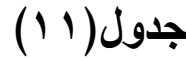

دلالة الفروق بين متوسطي الارياعى الأعلى والارياعى الأدنى

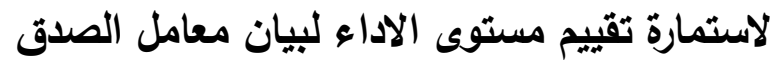

$r \cdot=\dot{s}$

\begin{tabular}{|c|c|c|c|c|c|c|c|c|}
\hline \multirow{2}{*}{ معامل } & \multirow{2}{*}{ 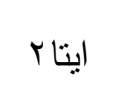 } & \multirow{2}{*}{ قيمة } & \multirow{2}{*}{ فروق المتوسطات } & \multicolumn{2}{|c|}{ الإباعى الادنى ن=0 } & \multicolumn{2}{|c|}{ الارباعى الاعلى ن=0 } & \multirow{2}{*}{ الاستمارة } \\
\hline & & & & $\varepsilon^{ \pm}$ & س & $\varepsilon^{ \pm}$ & س & \\
\hline$\cdot .9 \cdot 1$ &. . NYo & TH & $\varepsilon .970$ & 1.741 & 19.87. & 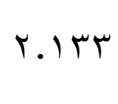 & TE.VYO & مستوبالاداء \\
\hline
\end{tabular}

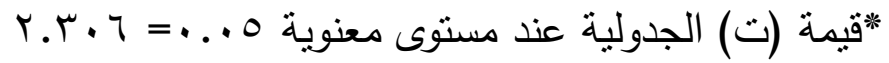

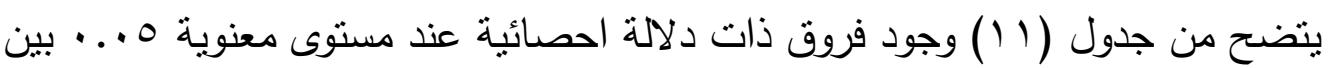

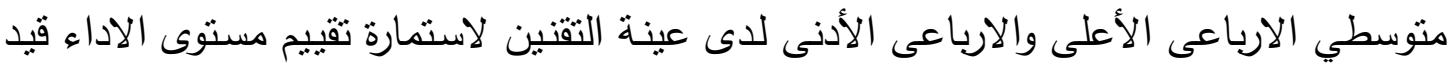

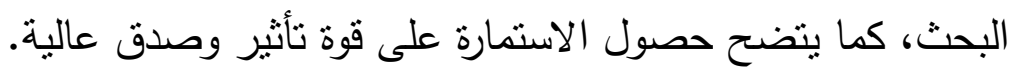
r-حساب ثبات استمارة التقييم الانيت

قام الباحثان بحساب معامل الثبات لاستمارة تقييم مستوى الاداء قيد البحث عن طريق

تطبيق المقياس على (·r) لاعب ممنلين لمجتمع البحث وإعادة تطبيقه مرة أخري يوم الثلاثاء

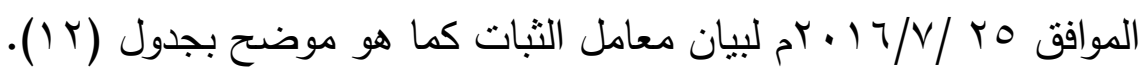




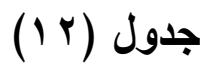

معامل الارتباط بين التطبيق واعادة التطبيق لاستمارة تقييم مستوى الاداء لبيان معامل الثبات $r \cdot=\dot{0}$

\begin{tabular}{|c|c|c|c|c|c|c|}
\hline \multirow{2}{*}{ الارتباط } & \multicolumn{2}{|c|}{ اعادة النطبيق } & \multicolumn{2}{|c|}{ النطبيق } & \multirow{2}{*}{ الاستمارة } & \multirow{2}{*}{ r } \\
\hline & $\varepsilon^{ \pm}$ & س ل س & $\varepsilon^{ \pm}$ & س س & & \\
\hline .940 & $r . T \leqslant Y$ & rY.乏A. & O.ETr & TY.TTO & تقييم مستوى الاداء & 1 \\
\hline
\end{tabular}

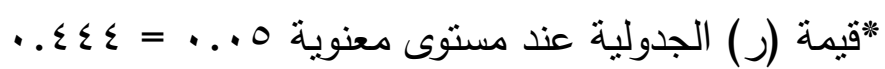
يوضح جدول (r ا) وجود ارتباط ذو دلالة احصائية بين التطبيق واعادة التطبيق (اعادة

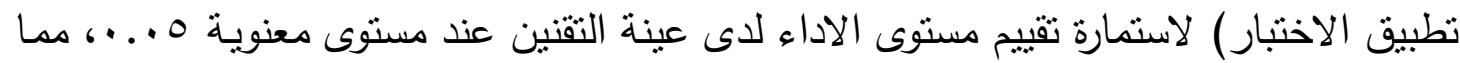

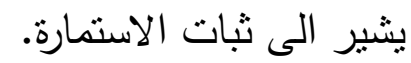
رابعاً: إجر اء الدراسة الأساسية: 1 الدر اسة الاستطلاعية:

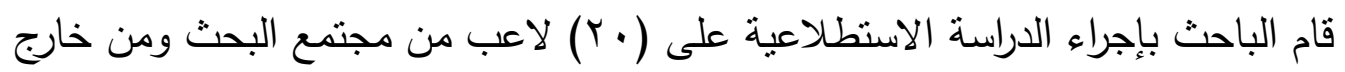

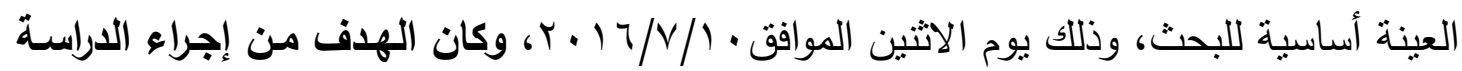
الاستطلاعية التعرف على الآتي: - مدى فهم عينة البحث لعبارات مقياس المتغيرات النفسية التي يتضمنها المقياس.

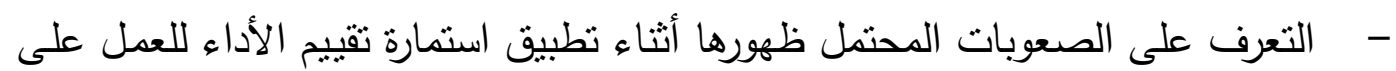
تلافيها.

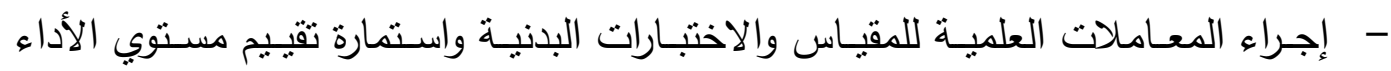

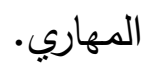

\section{وقد أسفرت نتائج الدراسة الاستطلاعية عن ما يلى:}

- فهم عينة البحث للعبارات التي يتضمنها المقياس حيث لم لم يبدِ أحد من السباحين عينة البحث استفساراً عن أي عبارة من عبارات المقياس.

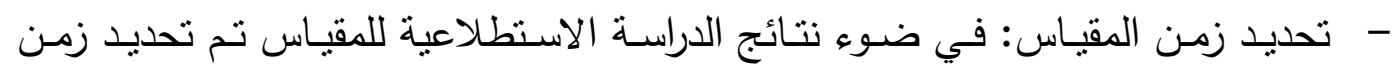

$$
\text { المقياس بـ (r اقن) تقريباً. }
$$

- تلافي الصعوبات المرتبطة بالاختبارات البدنية وبتصوير أداء عينة البحث لإجراء نقييم مستوي الأداء من خلال المحكمين.

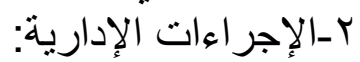

قام الباحثنان بالإجراءات الإدارية لتسهيل الإجراءات الخاصـة بالدراسـة وذلك بالحصول

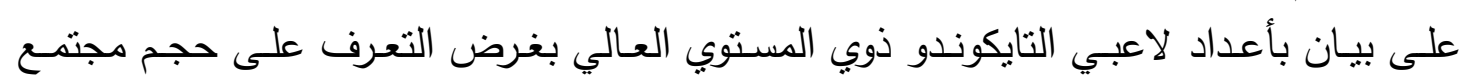

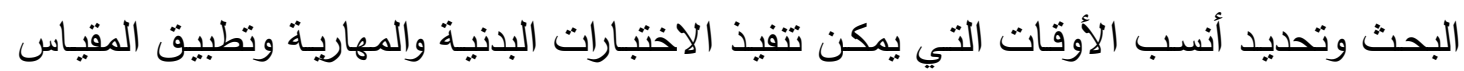
وكذلك الموافقة على إجراء وتطبيق الدراسة على عينة الدراسة. وقد قام الباحثان بمقابلة العينة المختارة بالطريقة العمدية في وجود المدرب بلة بهدف: 


$$
\begin{aligned}
& \text { - شرح أهداف البحث للعينة والتأكد من رغبتهم بالاشتراك في البحث. } \\
& \text { - تطبيق استمارة المقياس المستخدمة في البحث. } \\
& \text { r- تطبيق مقياس البحث: }
\end{aligned}
$$

بعد التأكد من توافر كافة الثروط العلمية للاختبارات البدنية مرفق (1) (l) وتقييم مستوي الأداء المهاري مرفق (V) ومقياس المتغيرات النفسية مرفق (0) للاعبي التايكوندو ،قام الباحثان

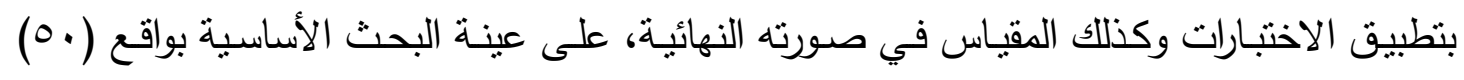

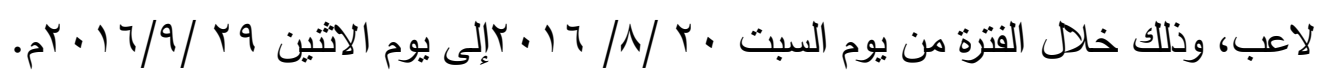

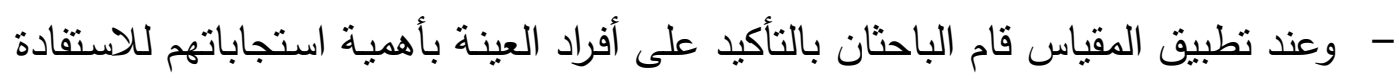

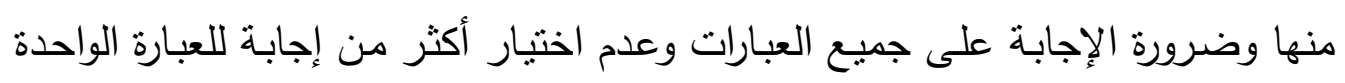
مع ضرورة قراءة التعليمات قبل الإجابة.

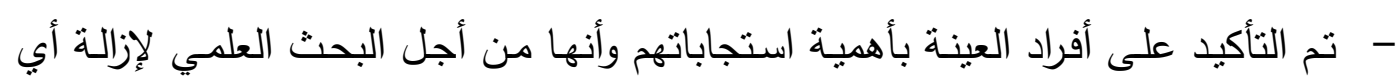
مخاوف قد تقلل من تفاعلهم في الإجابة على المقياس.

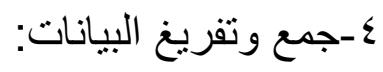

بعد الانتهاء من تطبيق الاختبارات البدنية والمهارية وكنلك استمارة المقياس قام الباحثان

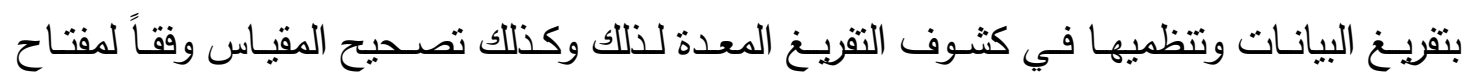

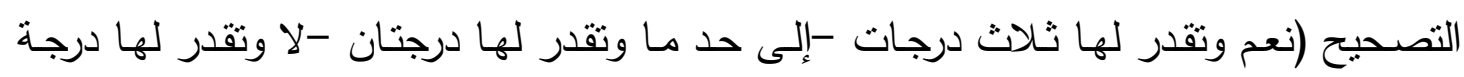

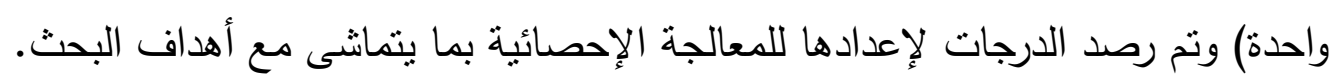
خامساً: المعالجات الإحصائية:

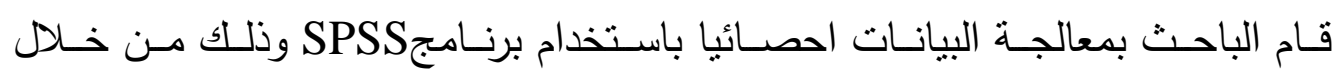
المعاملات الاحصائية التالية:

$$
\begin{aligned}
& \text { - الوسيط. } \\
& \text { - التقلطح. } \\
& \text { - النسبة المئوية (\%). } \\
& \text { - معامل ألفا كرونباخ. } \\
& \text { - الوزن النسبي. } \\
& \text { - نسبالسساهمة. } \\
& \text { - المتوسط الحسابي. } \\
& \text { - الانحراف المعياري. } \\
& \text { - الالتواء. } \\
& \text { - معامل الارتباط (ر). } \\
& \text { - معامل الاختلاف. } \\
& \text { - الأهمية النسبية. }
\end{aligned}
$$

تحليل عبارات المحور الاول الخاص بالقلق الرياضي

$0 .=0$ 


\begin{tabular}{|c|c|c|c|c|c|}
\hline الأهمية & الاختلاف معامل & الانحراف & المتوسط الحسابي & 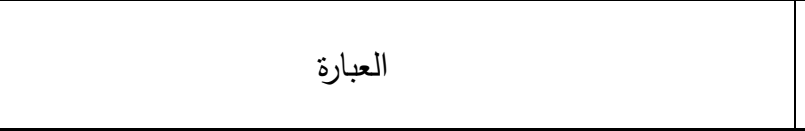 & r \\
\hline 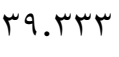 & r..01 &.$r q$. & 1.11. & أنثعر بـ (الارتباك، التوتز ، الضيق، العصبية، ...) قبل بدء المنافسة. & 1 \\
\hline$\varepsilon r .77 V$ & $0 \ldots \ldots$ & $.7 \varepsilon$. & $1 . r \wedge$. & |عضلاتي تكون مشدودة قبل اشتراكي في المنافسة. & r \\
\hline 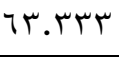 & rE.r\I & $\therefore \leqslant 7$. & $1.9 \cdots$ & |تتسارع دقات قلبي كلما اقترب ميعاد بدء المباراة. & r \\
\hline 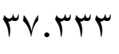 & rq. $\leqslant 7 \leqslant$ & 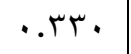 & $1.1 \mathrm{r}$ & |أخثى ارتكاب أخطاء خلص المنافسة. & $\varepsilon$ \\
\hline אוr. & $\sum \vee .0 \wedge 1$ &. .09 & $1 . r \leq$. & أرتكب مزبداً من الأخطاء كلما ازدادت أهمية المنافسة. & $\circ$ \\
\hline $7 \wedge . \ldots$ & $r \varepsilon \ldots . r \cdot$ & $\therefore \leqslant 9$. & r.. $\varepsilon$. & يمنعني (شعوري بالتوتز قبل المنافسة) من إجادة اللعب في المنافسة. & 7 \\
\hline $77.77 \mathrm{~V}$ & r.... & $.0 \%$. & r.... & |أفقد قدتي على ضبط انفعالاتي خلال المباراة. & v \\
\hline $7 \varepsilon .77 \mathrm{~V}$ & KE. KrV & $\cdot . \leqslant \vee \cdot$ & $1.9 \leq$ & |تخفض روحي الرياضية أثناء المنافسة. & $\Lambda$ \\
\hline r^.... & $r \cdot . v \cdot r$ &.$r 0$. & $1.1 \leq$. & |تقلقي آراء الآخرين في أدائي الرياضي. & 9 \\
\hline سT.TLE & $\varepsilon \varepsilon .710$ &. .01 & $1 . r \ldots$ & |أشعر بالتونز عندما بشاهد أدائي بعض الأشخاص المهمين. & $1 \cdot$ \\
\hline سT.M & $0 \ldots \ldots$ & .70 & $1 . r \ldots$ & |أشعر بالخوف عند حضور عداً كبيراً من الجمهور . & 11 \\
\hline$\varepsilon \cdot .7 T V$ & $\Sigma 0 . \wedge r$ &. .00 & I.T. & إيربكني اشتراكي مع منافس ذو مستوى عالي من الأداء. & it \\
\hline$\varepsilon \cdot .77 V$ & rะ. $\varepsilon r \tau$ & $\cdot \Sigma \zeta$. & I.Y. & |يصعب علىّ تقبل تعديل مدربي لخطة اللعب قبل بدء المنافسة مباشرة. & 14 \\
\hline אוT.T & $r \varepsilon . \varepsilon \wedge r$ & $.0 \ldots$ & $1 . \leqslant 0$. & |المتوسط العام للمحور & - \\
\hline
\end{tabular}

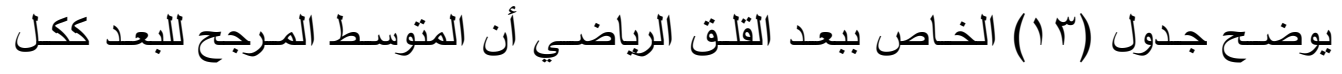

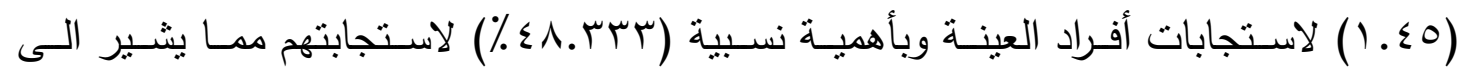
انخفاض مستوي القلق الرياضي المرتبط بالمنافسة لاى لاعبي المستويات العليا. 


\section{جدول (؛ ( )}

\section{تحليل عبارات المحور الثاني الخاص بدافعية الانجاز}

$\bullet \cdot=\dot{0}$

\begin{tabular}{|c|c|c|c|c|c|}
\hline الأهمية & الاختلاف معامل & الانحراف المعياري & المتوسط الحسابي & العبارة & s \\
\hline $94.77 \mathrm{~V}$ & 19.7 .8 & $.0 \leqslant 0$ & 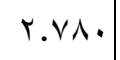 & ليمثل التفوق الرياضي أحد أهدافي الأساسية. & 1 \\
\hline $9 \varepsilon .77 \mathrm{~V}$ & $M . . r \Lambda$ & .rv. & Y.A $\leq$. & |أبذل قصارى جهدي حتى أكون أفضل لاعب. & r \\
\hline $9 \ldots .$. & Yr.VEI & $.71 \leqslant$ & r.V.. & |أرحب بالتدريب لساعات إضافية لتحسين أدائي. & r \\
\hline $9 \varepsilon \ldots$ & $10.0 \mathrm{Tr}$ &..$\leqslant \Gamma \wedge$ & $r . \wedge r$. & أستطيع أداء المهام التي يرى زملائي أنها مهام صعبة. & $\varepsilon$ \\
\hline $9 \ldots .$. & ro.111 &.$T \vee \wedge$ & $r . v .$. & أصمم على الفوز رغم تمتع المنافس لي بمستوى مرتفع من الأداء. & ○ \\
\hline سחז. זع & Or.10s &.$T \vee \wedge$ & $1 . r \cdot$ & |ارتكابي لخطأ في الأداء يؤثز على أعصابي طوال فترة المنافسة. & 7 \\
\hline $7 \wedge .77 \vee$ & $r \cdot .0 \wedge r$ & $\cdot . \leqslant r \leqslant$ & r... . & |أثعر بالتوتز قبل بدء المنافسة مباشرة. & 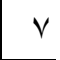 \\
\hline $94.77 V$ & $19.7 \cdot \varepsilon$ & $.0 \leq 0$ & 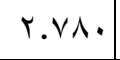 & |أخشى الهزيمة في المنافسة. & $\wedge$ \\
\hline 7..... & 17.111 & $\cdot .19$ & 1.91. & ليصعب عليّ النوم ليلة اشتراكي في المنافسة. & 9 \\
\hline אسז. & $10.1 . \varepsilon$ &.$\leqslant O Y$ & Ү.人૫. & |أنا دائم التقكير بما يمكن أن يحدث في المنافسة. & 1. \\
\hline ᄉ ..... & $r V \cdot r \cdot q$ & $\cdot V \cdot r$ & r.01. & |أحاسب نفسي عما ارتكبته من أخطاء في الأداء. & 11 \\
\hline $94.77 V$ & IT.TYT &. .401 & r.VA. & |الفوز في المنافسة يمنحني درجة عالية من الرضا. & ir \\
\hline $77 . .$. & IY. $\leqslant V 0$ & $. r \leq V$ & 1.91. & |أواصل التدربب بعد فوزي في المنافسة دون انقطاع. & 14 \\
\hline אזr. & 19.人 & $\therefore \leqslant q$ & Y. $\Sigma V \cdot$ & |المتوسط العام للمحور & \\
\hline
\end{tabular}

يوضـح جدول (ع () الخـاص ببعد بدافعيـة الانجـاز أن المنوسط المـرجح للبعد ككل

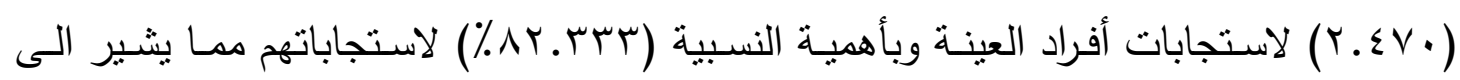
ارتفاع مستوي الدافعية للإنجاز لاى لاعبي المستوليات العليا. 


\section{جدول (10)}

تحليل عبارات المحور الثالث الخاص بتركيز الانتباه

$0 .=0$

\begin{tabular}{|c|c|c|c|c|}
\hline الألهية & الاختلاف & الانحراف & |الحستوسط| & العبارة \\
\hline 7..... & 17.111 &. .419 & 1.91. & ا أجيد التحليل السريع لأداء المنافس خلال المنافسة، والتعرف على مواطن قوته وضعفه. \\
\hline NV.rTH & r..7.r &. $.79 \mathrm{~V}$ & r.Tr. & r الديّ القرة على الروئة السربعة في مواقف اللعب. \\
\hline $9 \ldots .$. & Yr.V$Y 1$ & $.71 \leqslant$ & r.v.. & r أستطيع التفكبر في العديد من الحركات التي أنوبي أدائها أثثاء المنافسة. \\
\hline 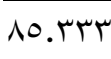 & rV.orq & $\because v \cdot 0$ & r.07. & ـ أركز انتباهي على عيد من الأفكار التي سأنفذها لمواجهة حركات المنافس. \\
\hline$\uparrow \varepsilon \ldots$ & rt.il ro & $\cdot . \leqslant \leq \leqslant$ & $1.94 \cdot$ & ه أحتفظ بانتباهي رغم تفكيري في عدة أمور في وقت واحد أثناء المباراة. \\
\hline $9 . . \cdot$ & rr.97r & $. .7 \leqslant V$ & r.v. & 7 أسنطيع ملاحظة أكثز من حدث يحلث في وقت واحد أثناء المنافسة دون أن أفقد تركيزي. \\
\hline qr... & $r \cdot .1 \cdot 9$ &. .000 & r.V7. & V أستطيع الاثتباه لموقق اللعب ككل. \\
\hline 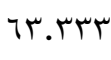 & rA. & $.0 \leqslant \leqslant$ & $1.9 .$. & ^ ميكنتي عزل تقكيري عن أي أفكار دخيلة أثناء المنافسة. \\
\hline 70.r & r9..人r &. $.0 \mathrm{~V}$. & 1.97. & 9 أحافظ على انتباهي بعيداً عن المؤثرات الخارجية أثناء المنافسة. \\
\hline $94.77 V$ & $19.7 \cdot 5$ & $.0 \leqslant 0$ & r.VA. & • ا اشتعوري بالتوتز قبل المنافسة لا يؤثز على نركيزي في كل ما بحثث داخل الملعب. \\
\hline $9 \ldots$ & $r \cdot .1 \leq \Lambda$ & $0.0 \leqslant \varepsilon$ & r.v. & 11 أستطيع اتخاذ القرار عنما أواجه موققاً له خيارات متعددة خلد المنافسة. \\
\hline A. $.77 \mathrm{~V}$ & rt.l $\varepsilon$. &. .07 & Y. $\Sigma Y$. & 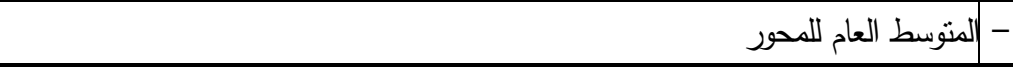 \\
\hline
\end{tabular}

يوضـح جـدول (0) الخـاص ببعـد بتركيز الانتبـاه أن المتوسـط المـرجح للبعـ ككل

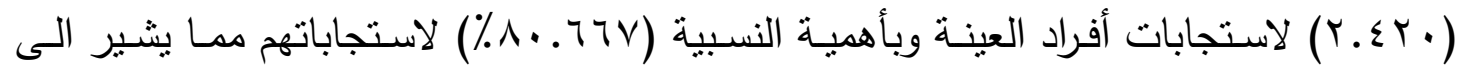

ارتفاع مستوي نركيز الانتباه لدى لاعبي المستويات العليا.

جدول (1 1)

المتوسط الحسابي والنسبة المئوية لتقييم مستوى الاداء لاى لاعبي التايكوندو

$1 \cdot 1$

\begin{tabular}{|c|c|c|c|c|c|}
\hline النسبة المئوبة & الدرجة العظمى & متوسط الدرجة & وحدةالقياس & مستوي الأداء المهاري & 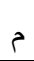 \\
\hline VY... & 1. & V.r.. & درجة & مهارة بك نشاجي & 1 \\
\hline$\vee \ldots .$. & 1. & $v_{.} .$. & درجة & مهارة نى تشاجي & r \\
\hline vr.... & 1. & V.r.. & درجة & مهارة نار ا تشاجي & r \\
\hline V $1.77 V$ & r. & r $1.0 \ldots$ & درجة & إجمالي مسنوى الأداء المهاري & \\
\hline
\end{tabular}

يوضـح جدول (7 (1) أن نتائج استمارة تقييم الحكام لمستوى اداء لاعبي التايكوندو ذوي

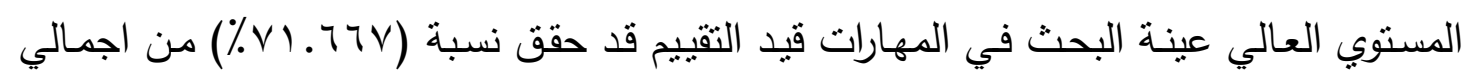
تقييم مستوي الأداء المهاري.

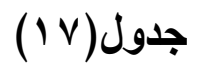




\section{مصفوفة الارتباط البسيط بين محاور مقياس المتغيرات النفسية على لإئ المستوى الاداء لاى لاعبي التايكوندو}

\begin{tabular}{|c|c|c|c|c|}
\hline مستوى تركيز الانتباه & دافعية الانجاز & القلق الرياضي & المتغيرات النفسية & b \\
\hline & & & القلق الرياضي & 1 \\
\hline & & . TYA & دافعية الانجاز & r \\
\hline & 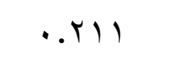 & $\ldots+1 \mathrm{~V}$ & مستوى تركيز الانتباه & $r$ \\
\hline${ }^{\star}, . \leq \varepsilon \varepsilon$. & 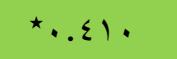 & *..T.r- & مسنوى الأداء المهاري & - \\
\hline
\end{tabular}

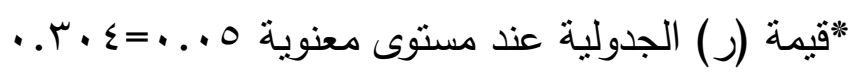

يوضح جدول (V) مصفوفة الارتباط البسيط بين ابعاد مقياس المتغيرات النفسية على

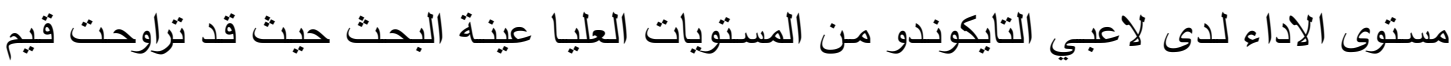

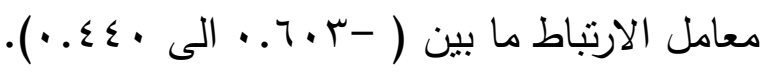
جدول (1)

مصفوفة الارتباط البسيط بين الاختبارات البننية على مستوى الاداء لاى لاعبي التايكوندو $0 .=$ ن

\begin{tabular}{|c|c|c|c|c|c|}
\hline مرونة مفصل & الرباعية & عرضة التوافن على & عداية متحركة منز & الوثب العرض الثبات & الاختبارات البدنية \\
\hline & & & & & ||لوثب العرض من الثبات \\
\hline & & & & $\cdot .1 \leq r$ & بعدو · متز بداية متحركة \\
\hline & & & $.011 \mathrm{~V}$ & $\cdot$.Yイ & ب|الوقوف على عرضة التوازن \\
\hline & & $\cdot .1 \cdot \varepsilon$ & $\cdot r \cdot \Lambda-$ & .879 & كُ |لوثبة الرباعية \\
\hline & .110 &. $.0 r$ & $\cdots \wedge 7$ & $\cdot .1 \leq \varepsilon$ & ] [مرونة مفصل الحوض \\
\hline$* .70 \leqslant$ & $* \cdot \cdot v \cdot r$ & $* . . V 7 \varepsilon$ & *..AYI- & $* .90 \leqslant$ & ــــــوى الأداء المهاري \\
\hline
\end{tabular}

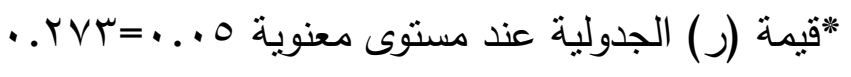

يوضح جدول (1) (1) مصفوفة الارتباط البسيط بين بعض المتغيرات البدنيةومستوى الاداء

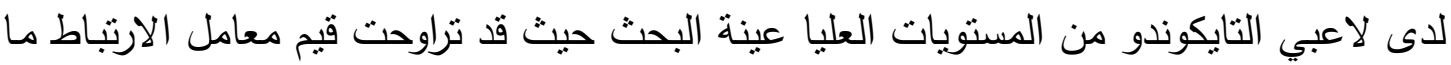

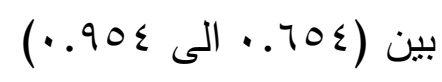




\section{جدول (19)}

تحليل الانحدار لأبعاد مقياس المتغيرات النفسية على مستوى الاداء لاى لاعبي التايكوندو

\begin{tabular}{|c|c|c|c|c|c|c|c|}
\hline نسبالمساهمة & \multicolumn{3}{|c|}{ معاملات الاتحدار } & |قيمة ف & المقدارالثابت & الخطألمعياري & المؤشرات المساهمة \\
\hline OY.rT & & &..$\leqslant 17$ & $\varepsilon r .7 \mathrm{~N}$ & 11.197 & r.70s & مستوى تزكيز الانتباه \\
\hline$T \leq . \leq \varepsilon$ & &. $\mathrm{r} T$ &.. $\mathrm{~T} V \mathrm{~A}$ & $r v .0 \leq 9$ & $1 \mathrm{IT.}+\mathrm{TV}$ & r.£०१ & مستوى تركيز الانتباه + القلق \\
\hline$V \varepsilon .7 \varepsilon$ &..$M 17$ &.. . 09 &..$M V I$ & M. & IV.17 & $0 . \mathrm{TVI}$ & مستوى تركيز الاثتباه + القلق +دافعية الاتجاز \\
\hline
\end{tabular}

يوضح جدول (9 () نتائج تحليل الانحدار لأبعاد مقياس المتغيرات النفسبة على مستوى

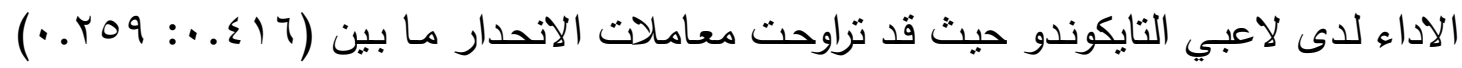
مما يشير الى أن الجزء الثابت من المتغيرات حقق قيمة موجبة أكبر من الصفر بالإضـافة الى هـ ان معامـل الانحدار لـه قيمـة موجبـة وتتراوح مـا بين (الصفر والواحد الصحيح). وكذلك نسب المساهمة المتغيرات النفسية في مستوى الاداء المهاري للاعبي التايكوندو من المستويات العليا

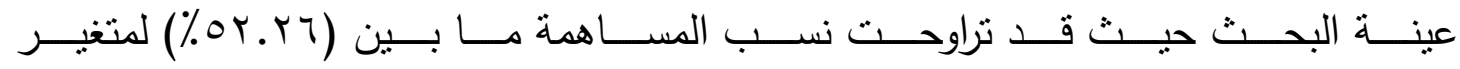

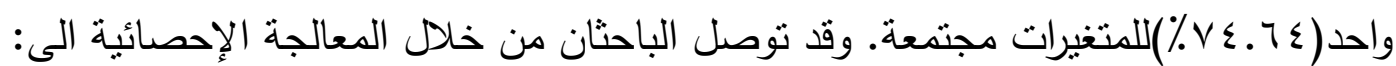
= = المتغير التابع ؛A=المقدار الثابت ؛ B= Bعامل الانحدار ؛ X= المتغير المستقل $\mathrm{Y}=\mathrm{a}+\mathrm{B} 1 \times 1+\mathrm{B} 2 \times 2+\mathrm{B} 3 \times 3$

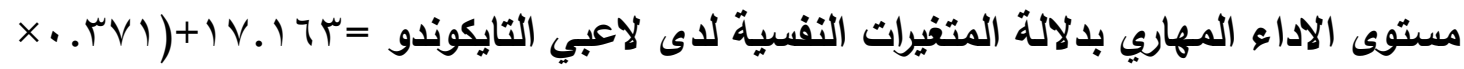

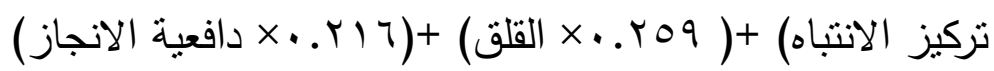

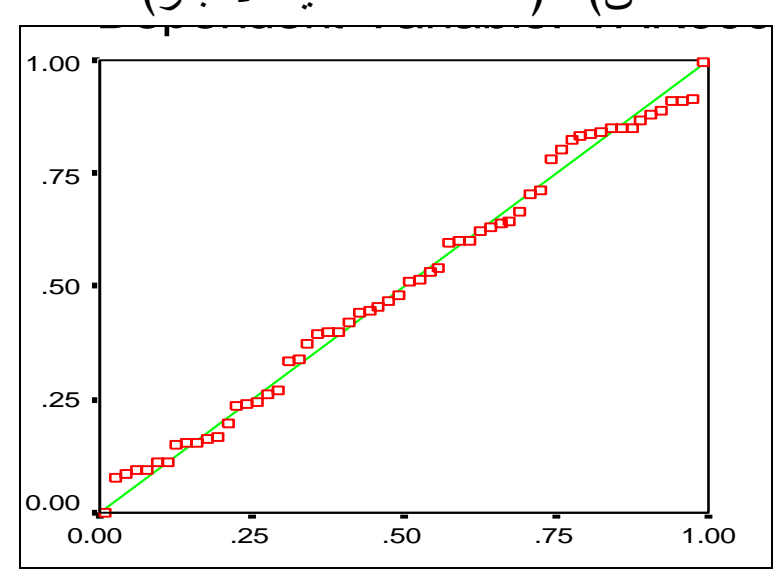

شكل (1) (1)

نقاط انتشار نتائج عينة البحث حول الخط المستقيم لأبعاد مقياس المتغيرات النفسية على مستوى الاداء المهاري لاى لاعبي التايكوندو من المستويات العليا 


\section{جدول (r) - (ץ)}

تحليل الانحدار للاختبارات البدنية على مستوى الاداء لاى لاعبي التايكوندو

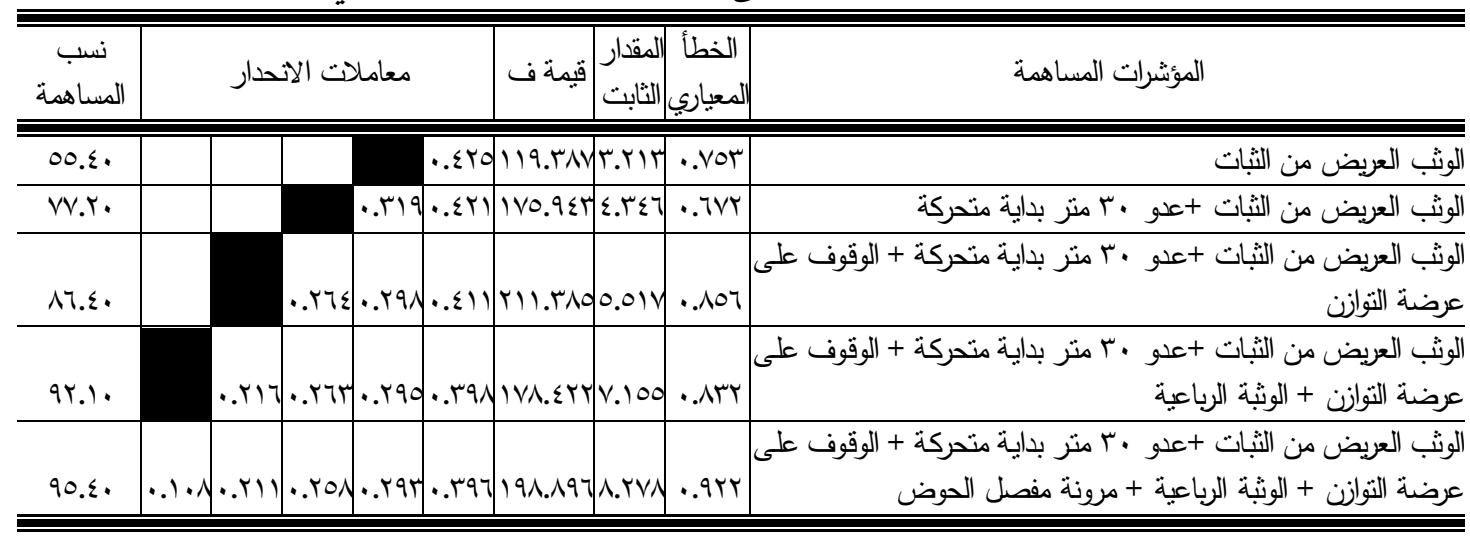

يوضح جدول ( • ب) نتائج تحليل الانحدار للاختبارات البدنية للمتغيرات اللياقة البدنية الخاصة

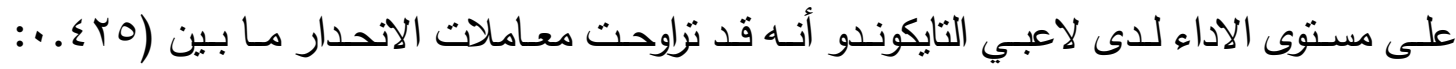

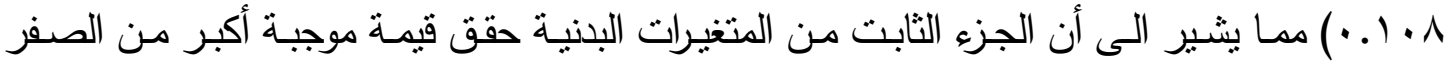

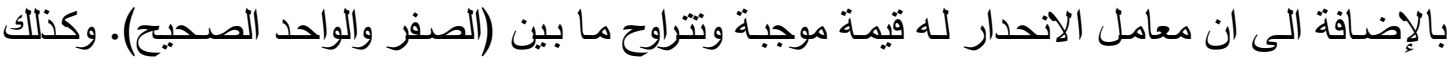
نسب المساهمة المتغيرات البدنية في مستوى الاداء المهاري للاعبي التايكوندو من المستوبات العات العليا

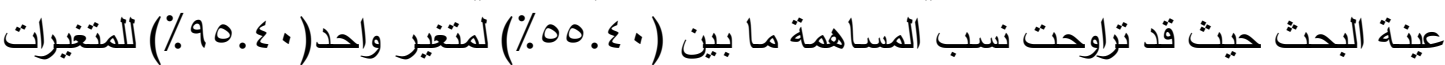
مجتمعة. وقد توصل الباحثان من خلا المعالجة الإحصائية الى

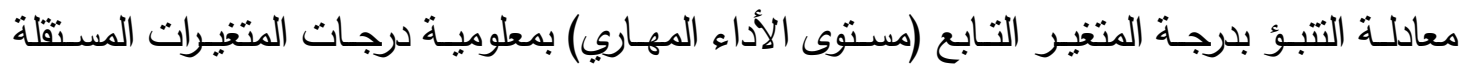
(المتغيرات البدنية) قيد البحث بالصورة الصغوة التالية:

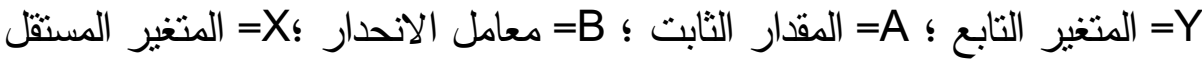
$\mathrm{Y}=\mathrm{a}+\mathrm{B} 1 \times 1+\mathrm{B} 2 \times 2+\mathrm{B} 3 \times 3+\mathrm{B} 4 \times 4+$ B $5 \times 5$

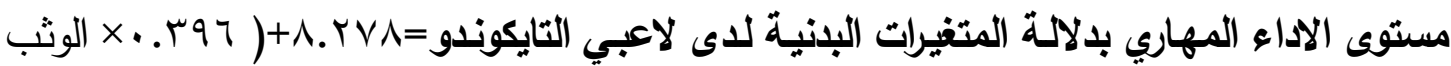

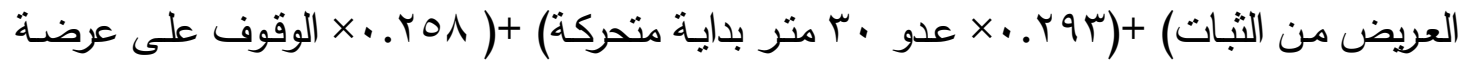

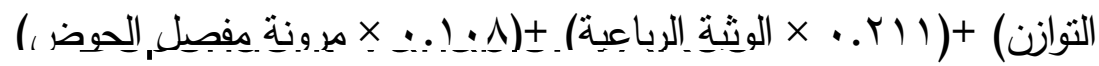

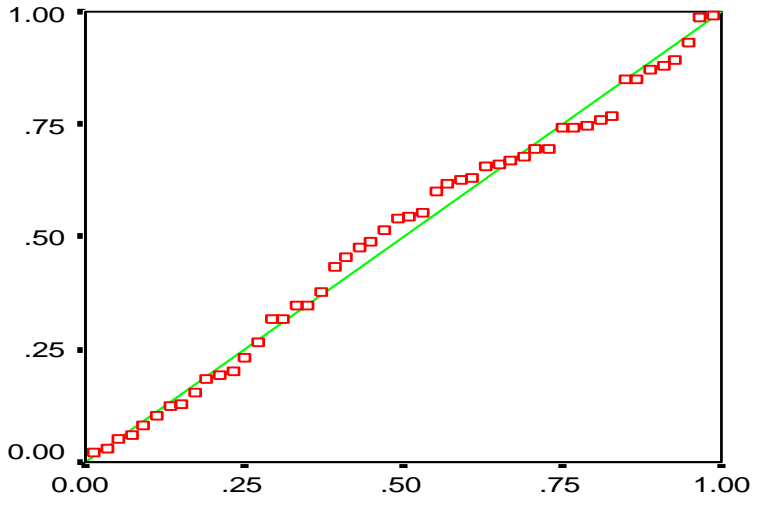

شكل (r) (r)

نقاط انتثار نتائج عينة البحث حول الخط المستقيم للمتغيرات البذنيةعلى مستوى الاداء المهاري لاى لاعبي التايكوندو من المستويات العليا 
مناقتشة نتائج الفرض الأول: يوجد مؤشر ايجابي لمستوي بعض المنتغير ات النفسية المختارة للاعبي التايكوندو ذويالمستويات العليا عينة البحث. بالرجوع إلى نتائج جذول (r آ ). يتضح ما يلي: اظهرت استجابات افراد عينة البحث من لاعبي التايكوندو ذوي المسنوي العالي عينة البحث انخفاض مستوي تأثير القلق الرياضي المرتبط بالمنافسة لدى لاعبي المستويات العليا.

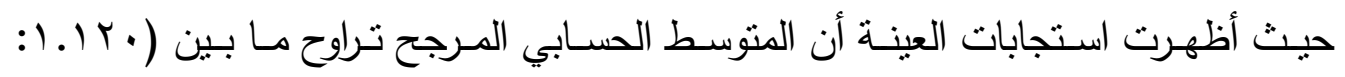

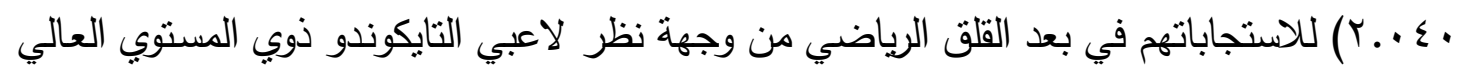

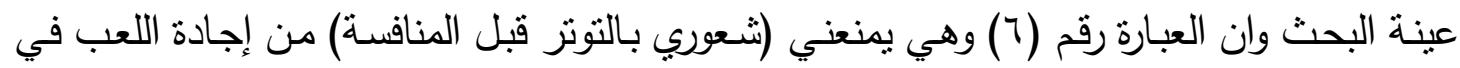

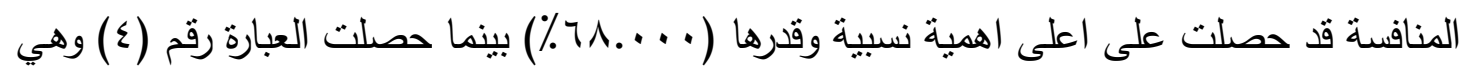

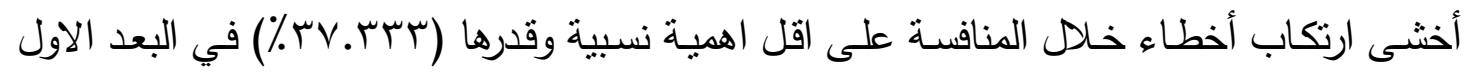

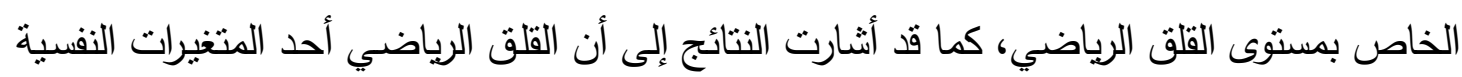

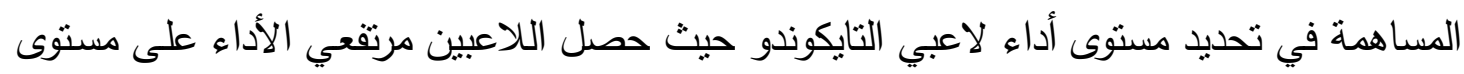
قلق رياضي يقع في درجة (نادراً) أب مستوى منخفض حيث حصل على متوسط مرجح (0ء ــ ( )

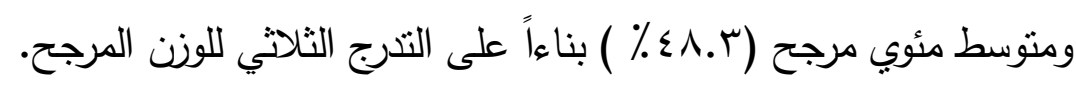

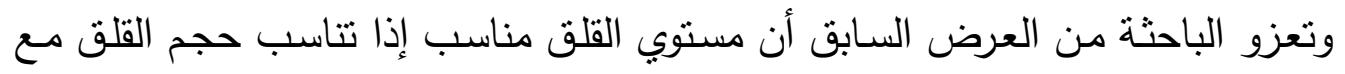
الخطر المتوقع حدوثه مما لا يؤثر على مستوي لاعب التايكوندو (المستوي العالي) على أهمية

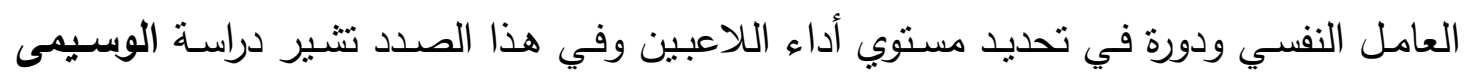

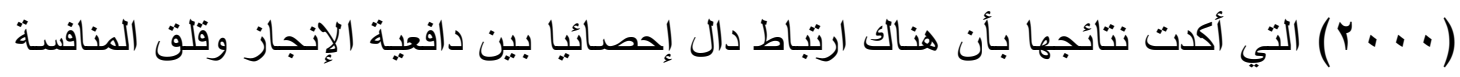

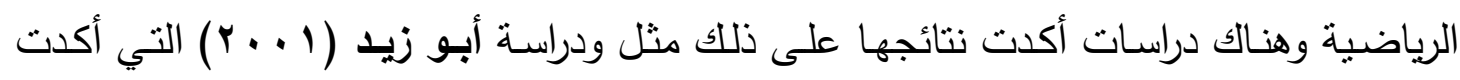

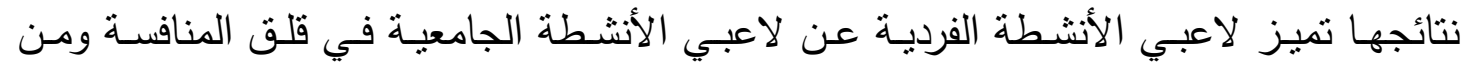

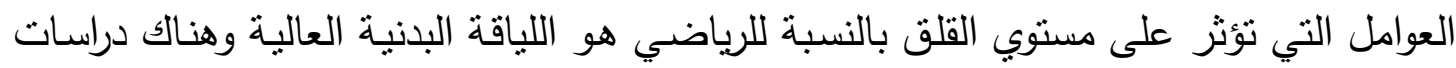

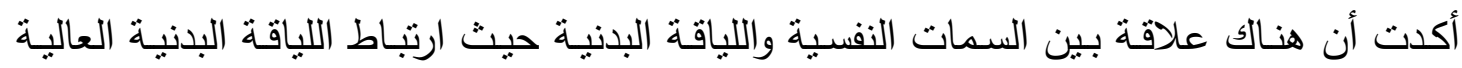
بتحسين مستوي القلق مثل دراسة (Matsumoto, et al 2001).

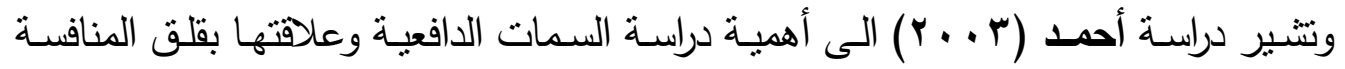

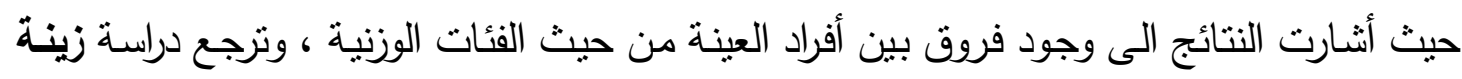

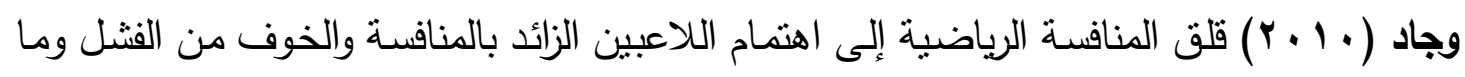

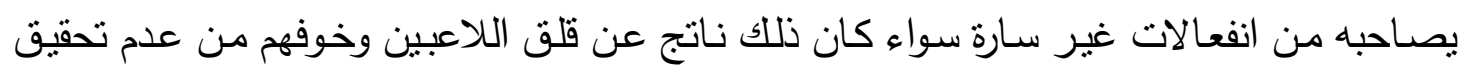

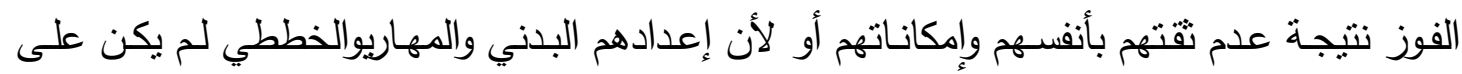
المستوى المطلوب وهو الأمر الذي يسهم في ارتفاع مستوى محاولة تجنبهم للفتشل. 


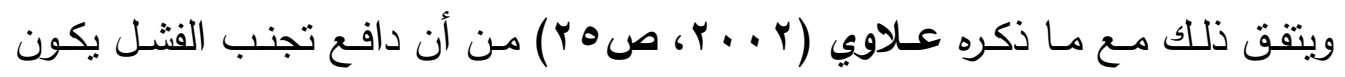

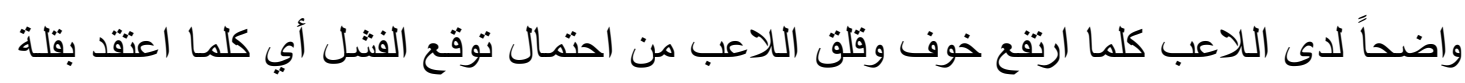

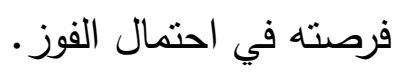

وبناءاً عليه فإن القلق الرياضي كمتغير نفسي لـه أهمية في الأداء الرياضي التتافسي

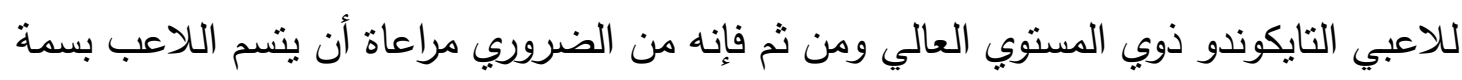

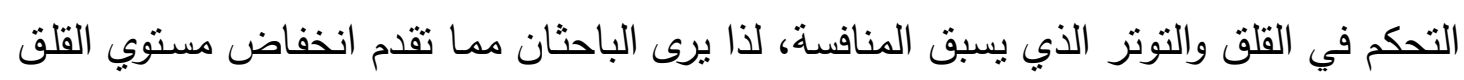

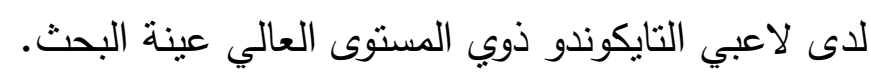

بالرجوع إلى نتائج جدول (ع ا ).

يتضح ما يلي: اظهرت استجابات افراد عينة البحث من لاعبي التايكوندو ذوي المستوي العالي عينة

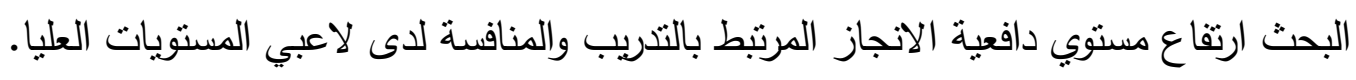

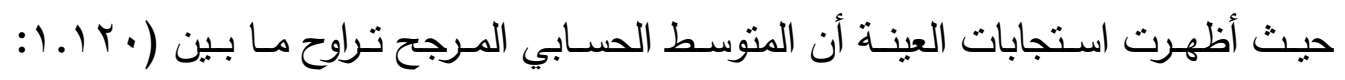

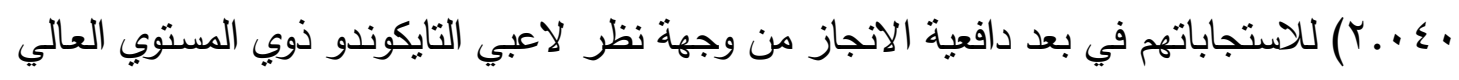

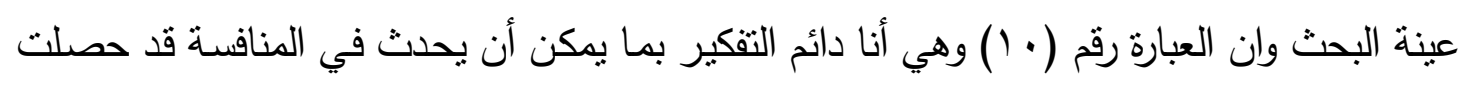

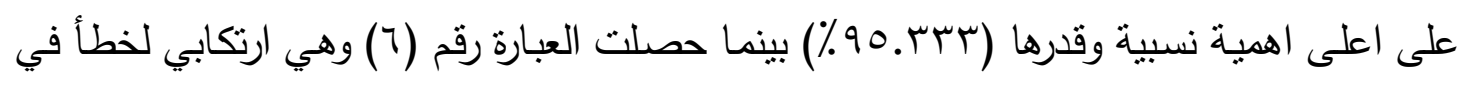

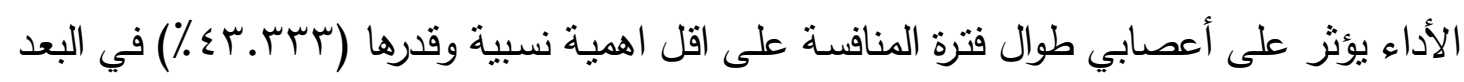

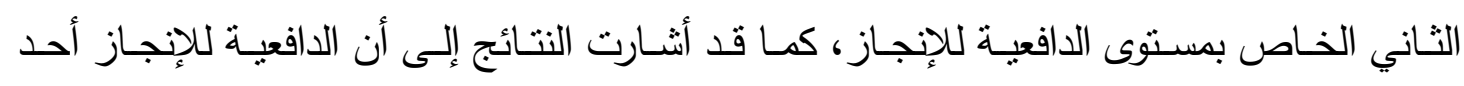

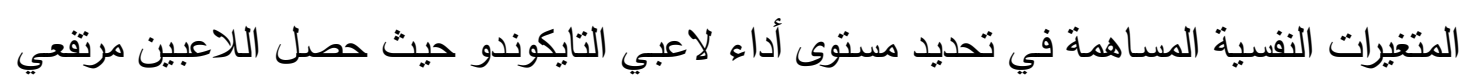

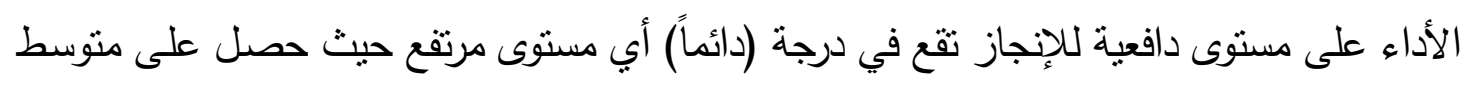

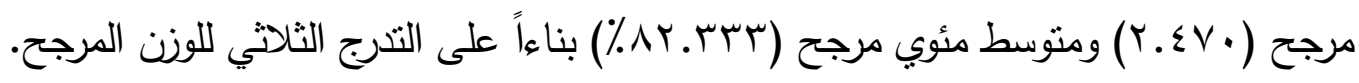
ومن خلال ما تقام تنفق بعض الدراسات التي أكدت على أن دافعية الإنجاز أحد الدتغيرات

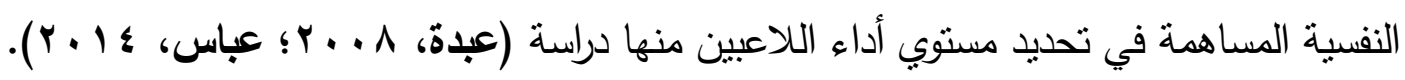

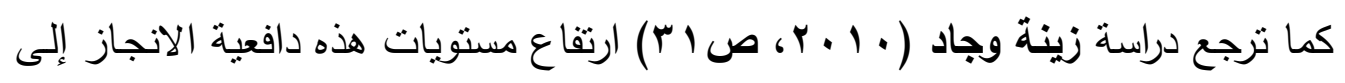

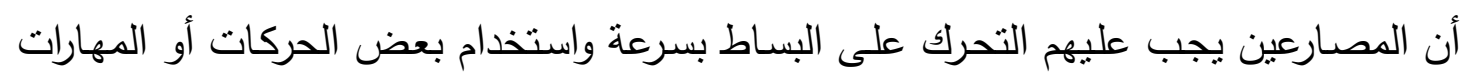

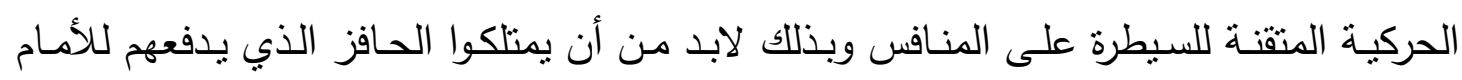

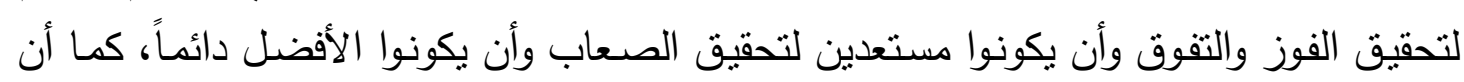

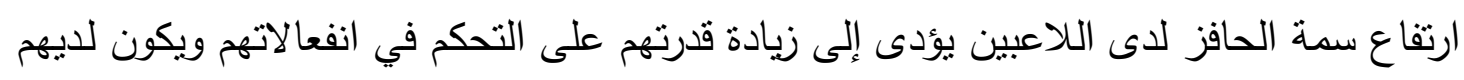

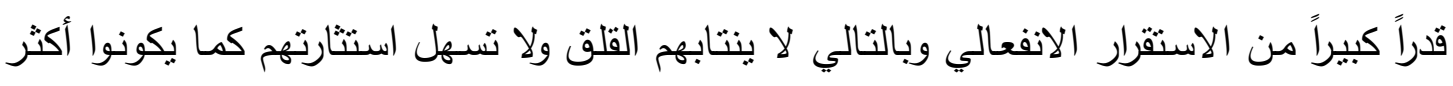

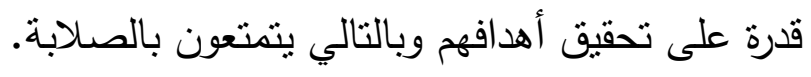




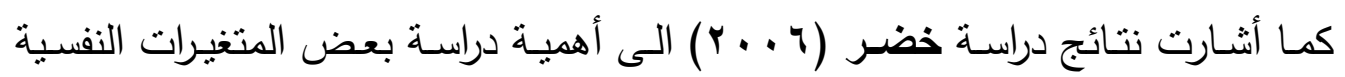

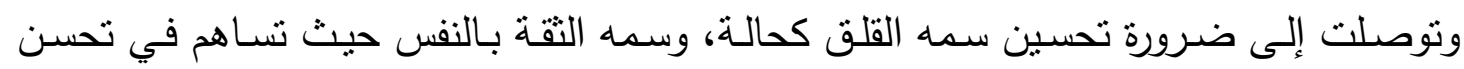
مستوى الأداء للطالبات في رياضة الجودودو.

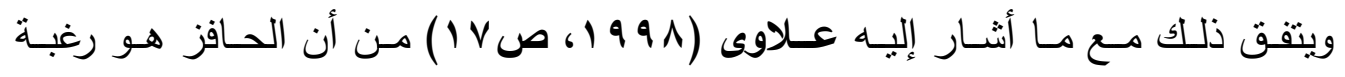

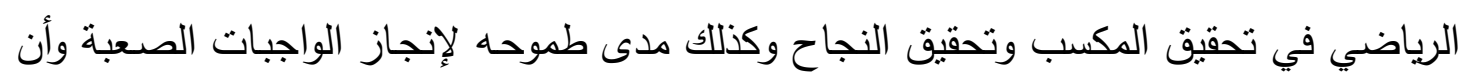
يسعى لان يكون رياضيا ممتازا.

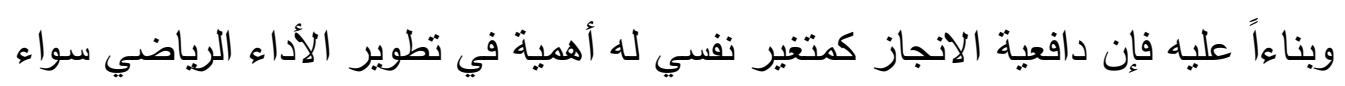

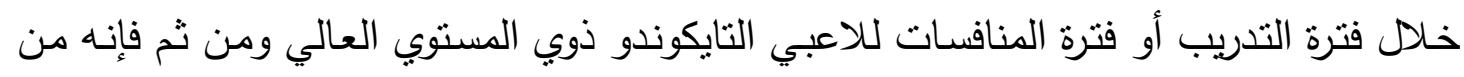

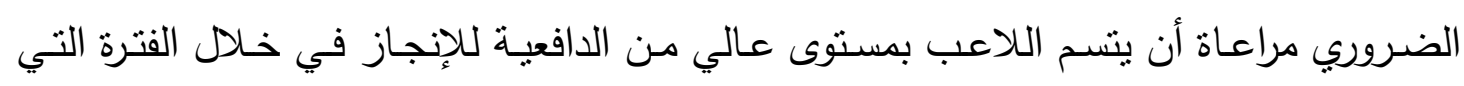

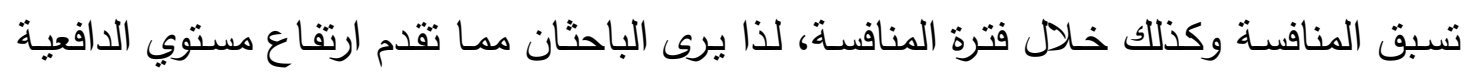

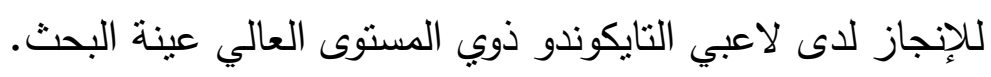

بالرجوع إلى نتائج جدول (10) يتضح ما يلي: اظهرت استجابات افراد عينة البحث من لاعبي التايكوندو ذوي المسنوي العالي عينة

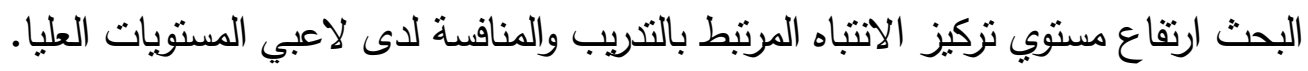

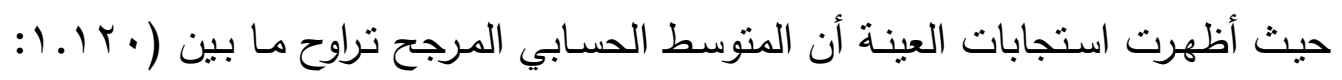

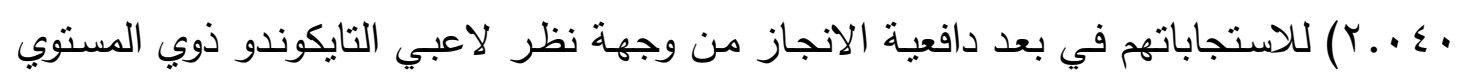

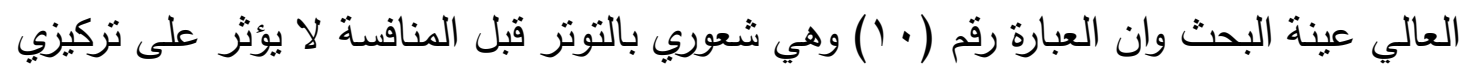

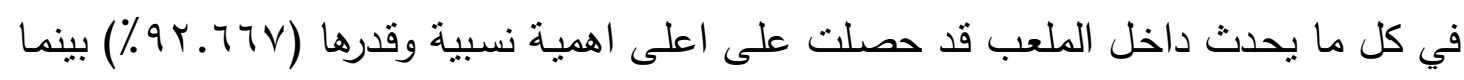

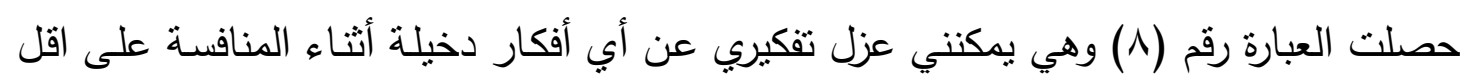

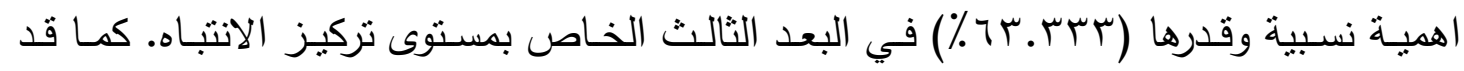

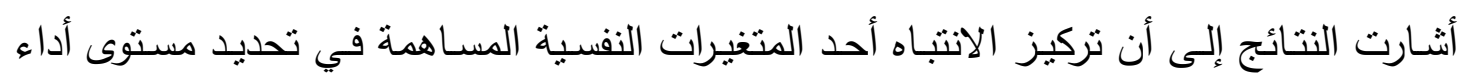
لاعبي التايكوندو حيث حصل اللاعبين مرتفعي الأداء على مستوى تركيز للانتباه يقع في درجة التباه

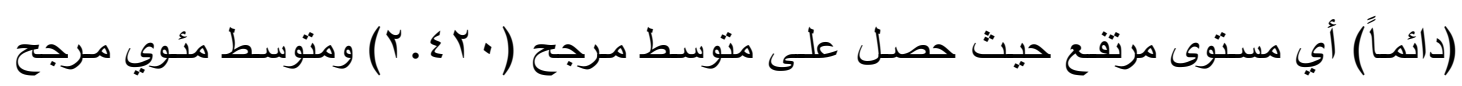

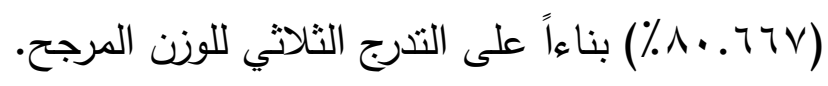

ومن العرض السابق يعزو الباحثان هذه النتائج إلى أن تركيز الانتباه أحد المتغيرات

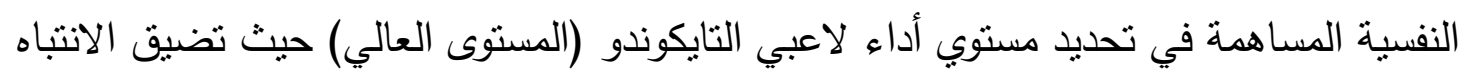

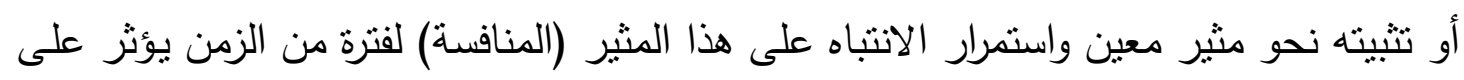

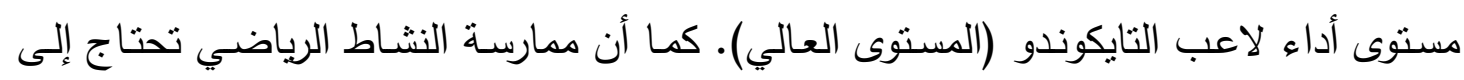


المتطلبات النفسية بجانب المتطلبات البدنية وبالأخص للاعبين ذو المستوى العالي ومدى أهمية

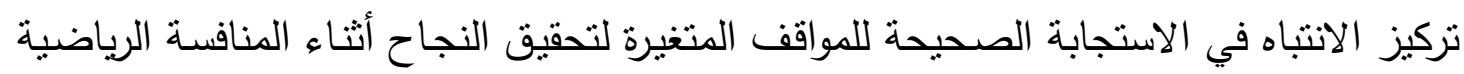
هو خير دليل على أهمية العامل النفسي وأكدت الدراسـات على ذلك كدراسـة كل من دراسـة

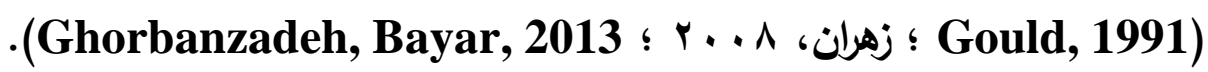
وتثير دراسة حكمت وآخرون (ه . . ץ) الى أهية دراسة خصائص الانتباه ومستوى أداء

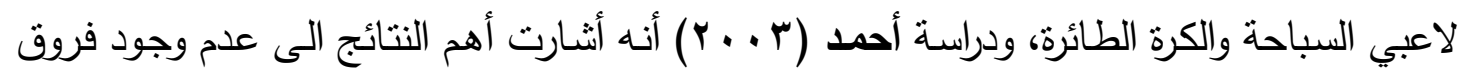
داله بين لاعبي الكاراتيه وفقاً لفئات الأوزان في الخصائص والارتباط الدال بين الدتغيرات الدافعية والالنتباه.

وبناءاً عليه فإن تركيز الانتباه كمتغير نفسي له أهمية في تطوير الأداء الرياضي سواء

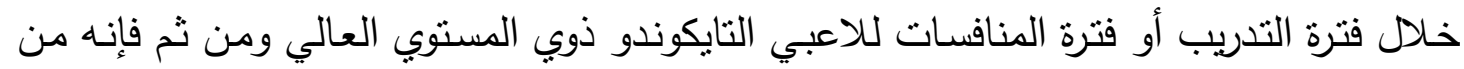

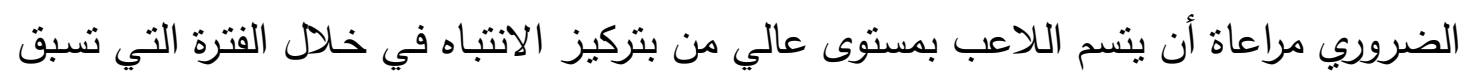

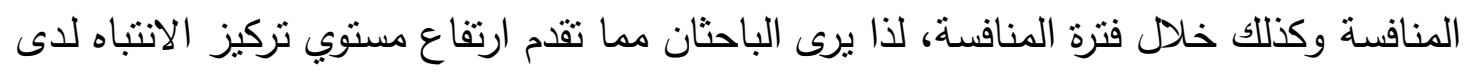
لاعبي التايكوندو ذوبي المسنوى العالي عينة البحث.

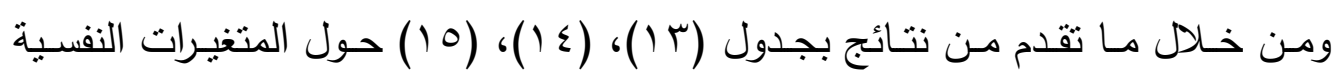

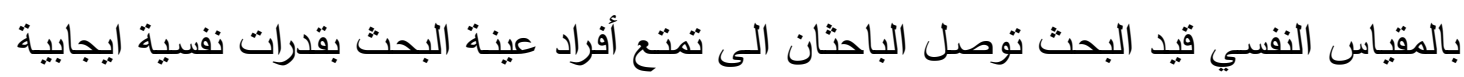

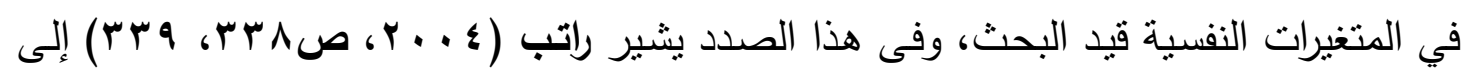
أن حدوث القلق وضعف التركيز وعدم التأكد من الهدف وكذلك فإن الرياضيين الذين فقدوا الثقة بالنفس يكون تركيزهم نحو نقاط الضعف مما يصرف انتباههم عن الأشياء الضرورية للأداء الجيد. وإضافة إلى هذا فإن الرياضيين الذين يفتقدون هذه الصفة قد يراودهم الثعور بعدم الكفاية

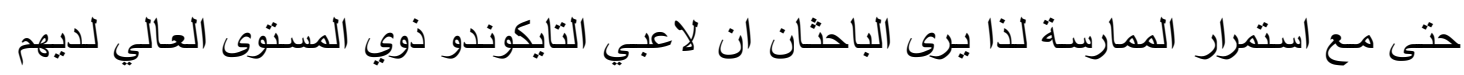

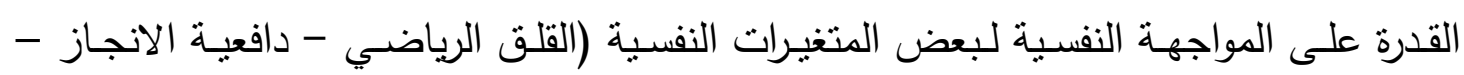

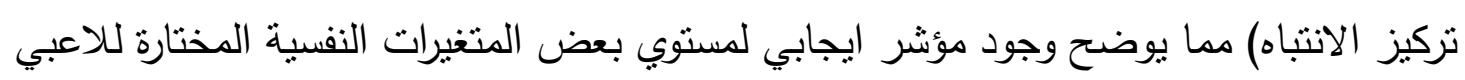

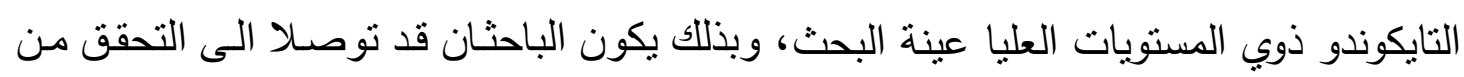
صحة الفرض الأول.

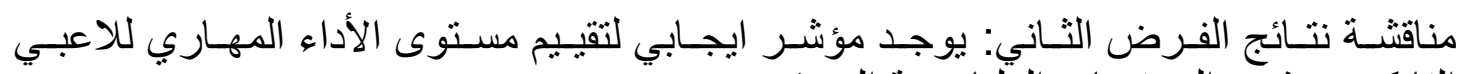
التايكوندو ذوي المستويات العليا عينة البحث.

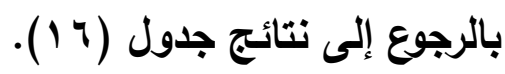


يتضح ما يلي: اظهرت نتائج افراد عينة البحث من لاعبي التايكوندو ذوب المستوي العالي عينة

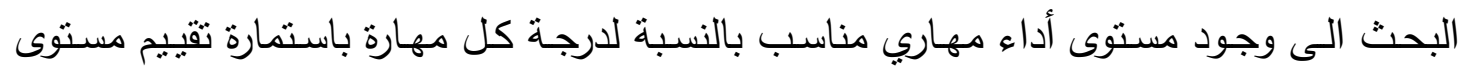
الأداء المهاري لدى لاعبي المستويات العليا.

حيث أظهرت نتائج تقييم مستوى الأداء المهاري أن المتوسط الحسابي لدرجة المهارات

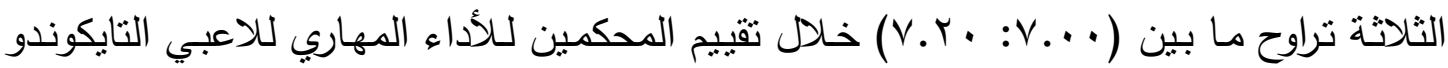
ذوب المستوي العالي عينـة البحث ان مهارة نـارا تثـاجي قد حصلت على العى اعلى نسبة وقدرها

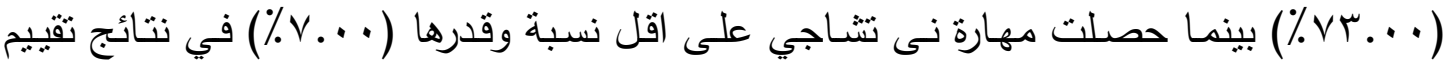

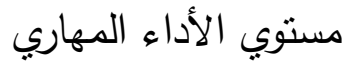

ومن خلال ما تقدم يتضح وجود مستوي مهاري عالي للاعبي التايكوندو عينـة البحث

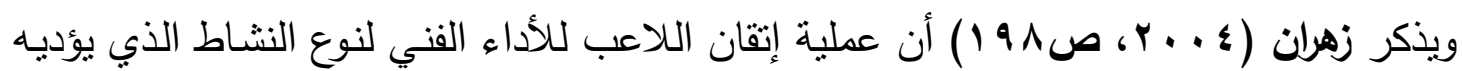

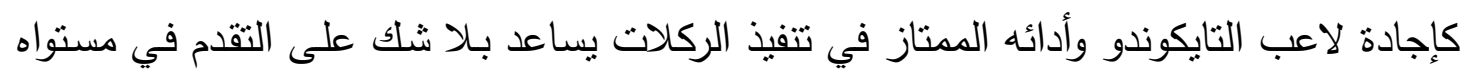

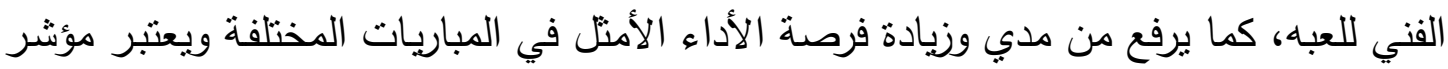

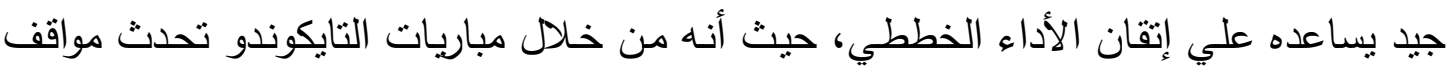
عديده بين كلا اللاعبين، تحتم علي اللاعب استخدام مهارات معينه لتحقيق أكبر فائدة والفوز في باتي

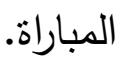

ويشير حماد ( ( . Y، ص ه) من يتطلب الوصول للمستويات الرياضية العالية استخدام الأسلوب العلمي لتخطيط وتوجيه عملية التدريب الرياضي، كما خطي التدريب الرياضي خطوات

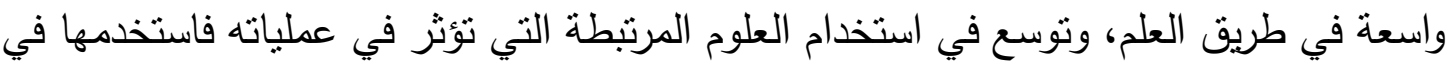

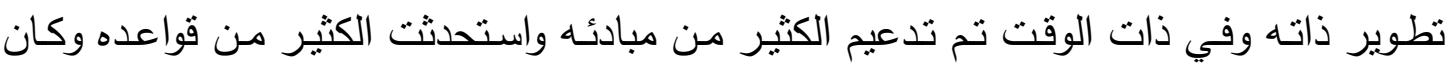

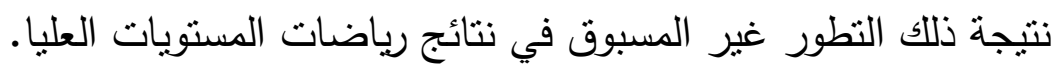

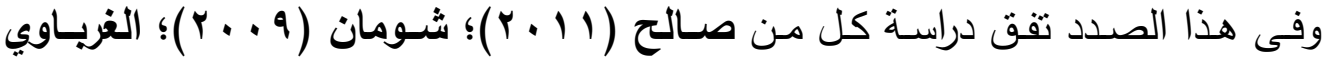

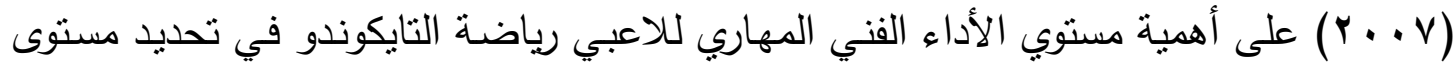

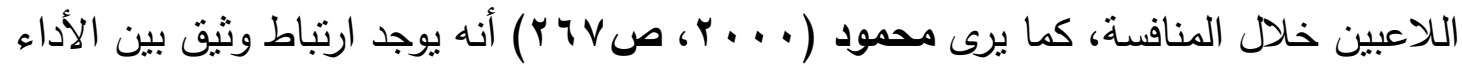

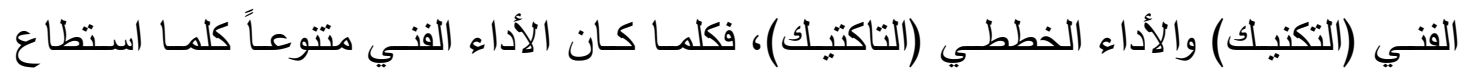

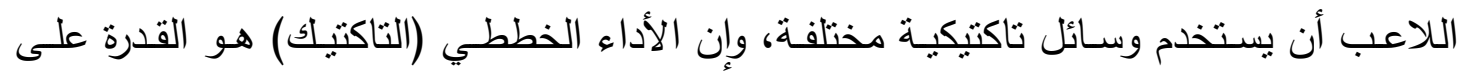
استخدام هذا السلاح وفقاً لمجريات المنافسة.

وبناءاً عليه فإن تقييم الأداء المهاري كمتغير يظهر مستوي الأداء المهاري لعينة البحث

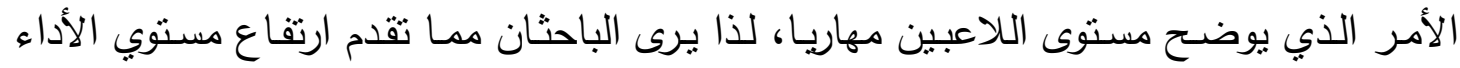
المهاري لاي لاعبي التايكوندو ذوي المستوى العالي عينة البحث، وبذللك يكون الباحثان قد تحققا

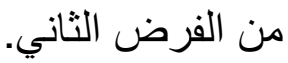




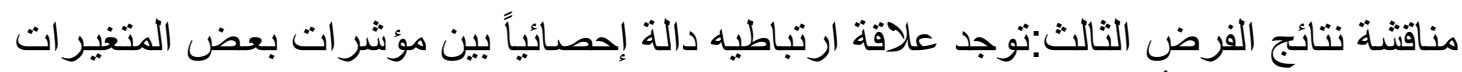

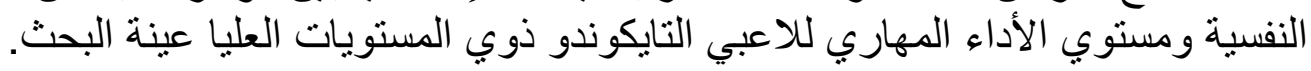

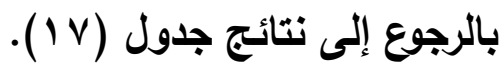

يتضح ما يلي: اظهرت نتائج افراد عينة البحث من لاعبي التايكوندو ذوي المستوي العالي عينة

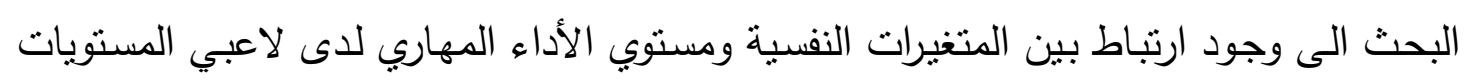
العليا عينة البحث.

حيث أظهرت النتائج أن مصفوفة الارتباط البسيط بين ابعاد مقياس المتغيرات النفسية

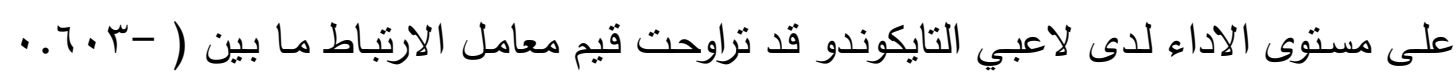

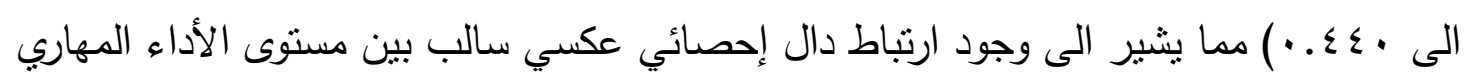

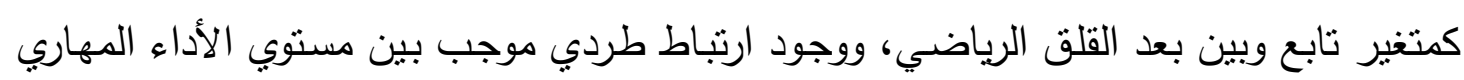
وبعد دافعية الإنجاز وتركيز الانتباه بمقياس المتغيرات النفسية قيد البحث.

وفى هذا تثير دراسة على (17 + ب ) إلى وجود علاقة ارتباطية ذات دلالة إحصائية بين الثقة بالنفس كسمة أو كحالة وأبعاد الأداء الرياضي للاعبي كرة القدم من الفرق الجامعية عينة

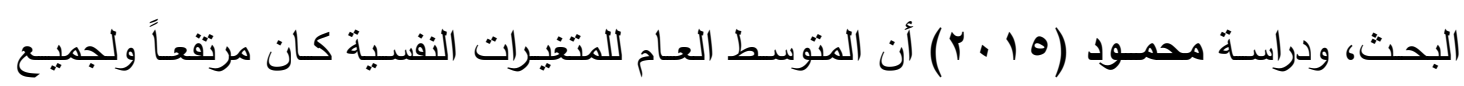

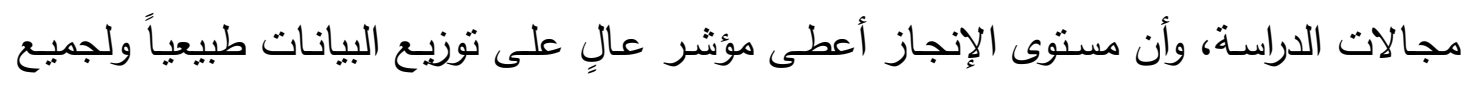

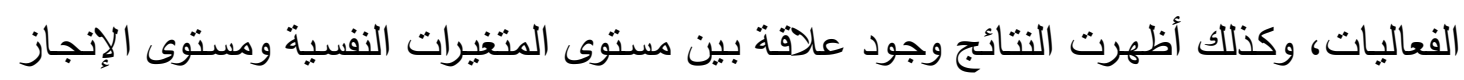
في جميع متغيرات الدراسة.

لذا فإن الإنجاز في المسابقات الرياضية يعتبر من أفضل العوامل التي توضـح ثقة الفرد

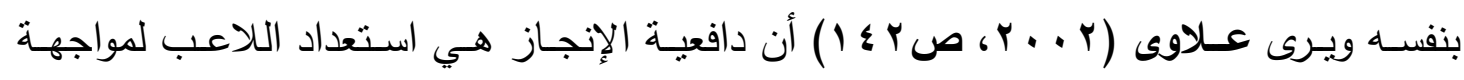

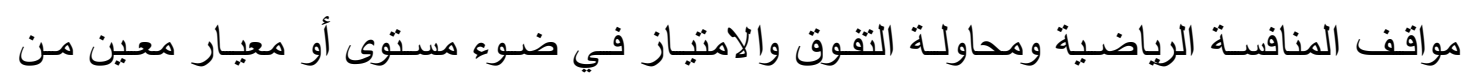
مستويات أو معايير التفوق والامتياز عن طريق إظهار أكبر قدر مدكن من النشاط والفاعلية

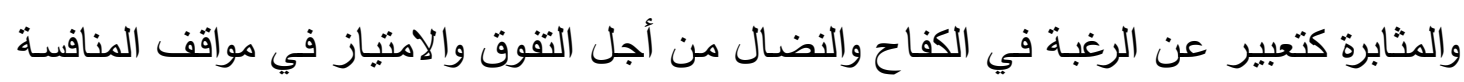
الرياضية.

يشير أولبورت إلى أن هناك سمات عديدة مرتبطة بصورة إيجابية ببعضها الآخر ، فإذا عرفنا

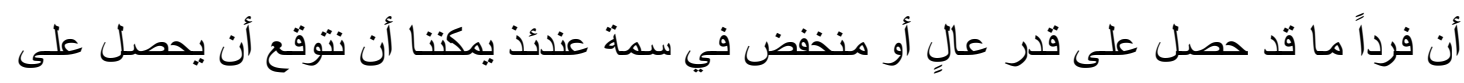

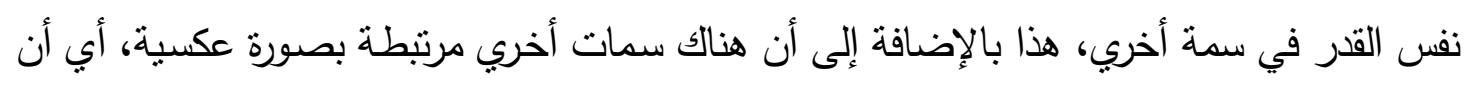

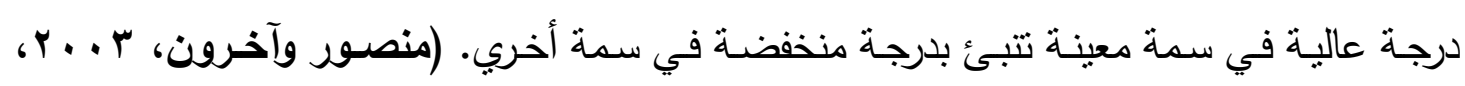




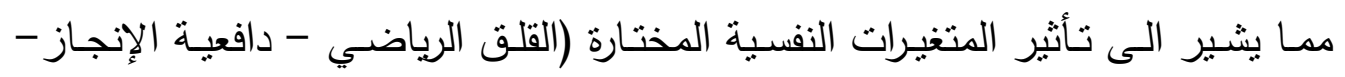

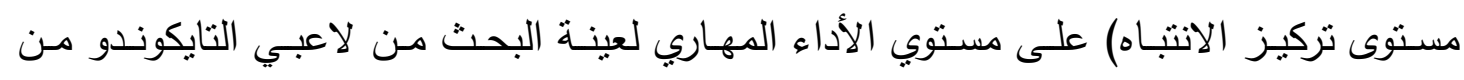
المستويات العليا، وبذلك يكون الباحثان قد تحققا من الفرض الأبات الثالث.

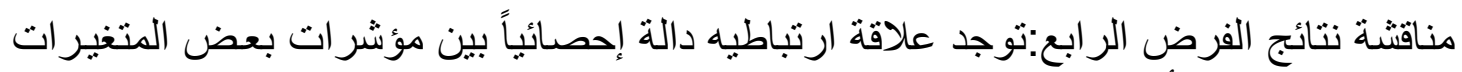

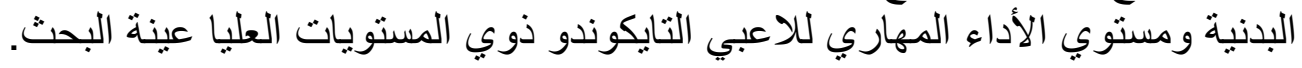

\section{بالرجوع إلى نتائج جذول (1 (1).}

يتضح ما يلي: اظهرت نتائج افراد عينة البحث من لاعبي التايكوندو ذوب المستوي العالي عينة

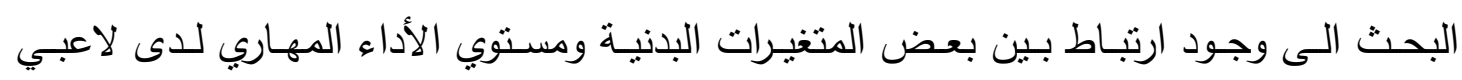
المستويات العليا عينة البحث.

حيث أظهرت النتائج أن مصفوفة الارتباط البسيط بين المتغيرات البدنية على مستوى

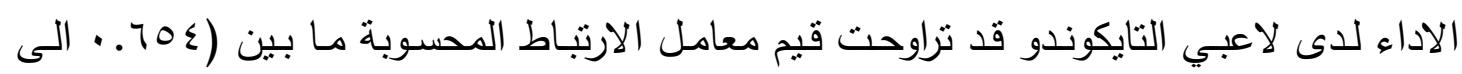

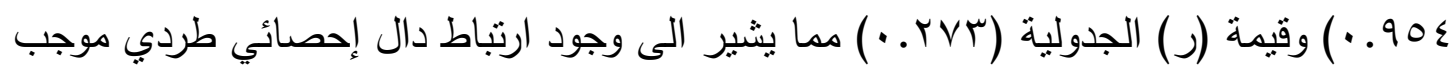

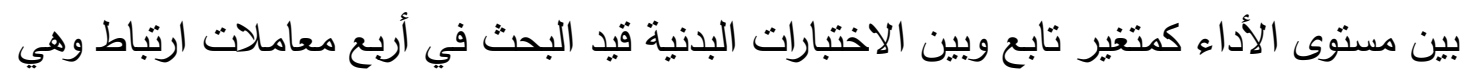

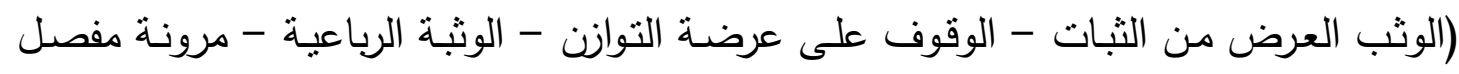

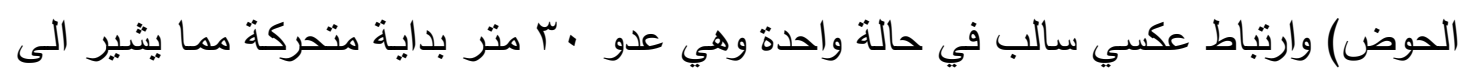

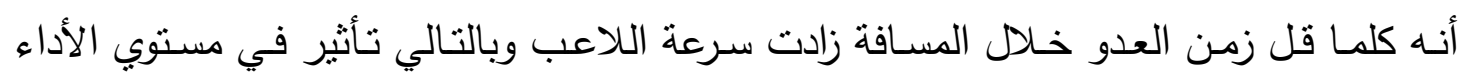
المهاري كمؤشر على السرعة الحركية عند أداء المهارة .

وتتفق نلك النتائج مع الدراسات التي تمت في مجال رياضـة التايكوندو وكذلك رياضات

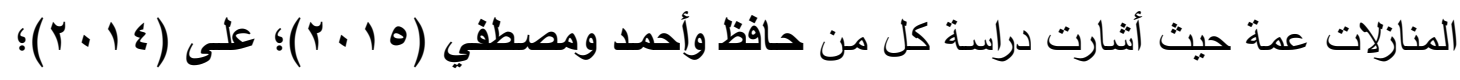

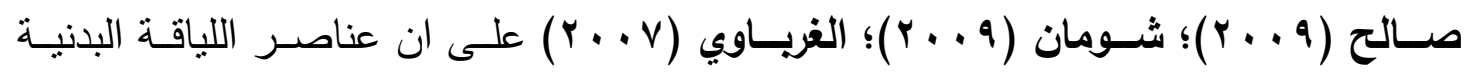

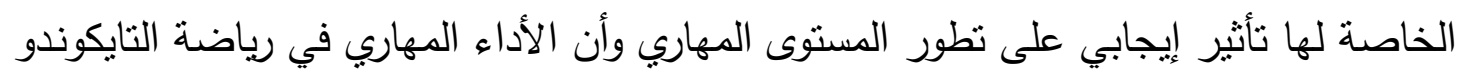

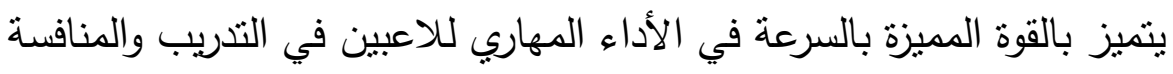

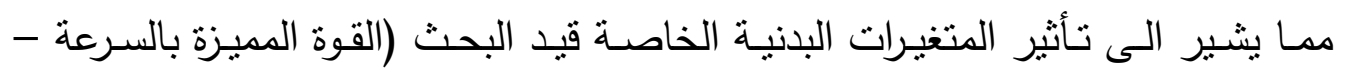

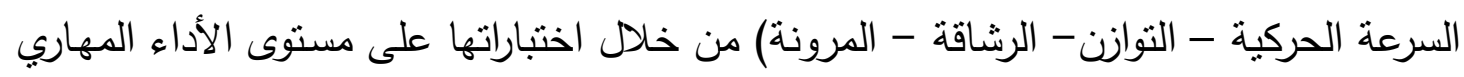

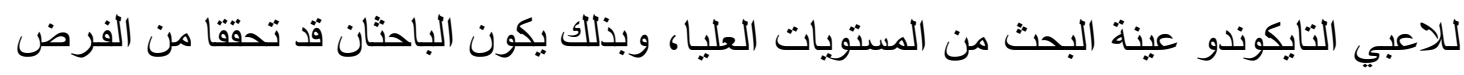
الر ابع.

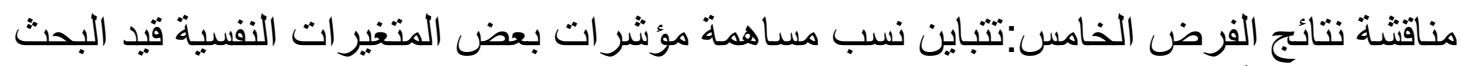
في مستوى الأداء المهاري للاعبي التنايكوندو ذوي المستويات العليا عينة البحث. 
يتضح ما يلي: اظهرت نتائج تحليل المتغيرات النفسية لأفراد عينة البحث من لاعبي التايكوندو ذوي المستوي العالي عينة البحث اختلاف نسب مساهمة المتغيرات النفسية على مستوى الأداء المهاري للاعبي التايكوندو ذوب المستوي العالي عينة البحث.

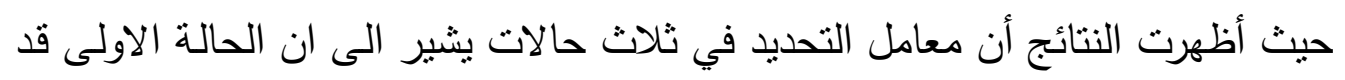

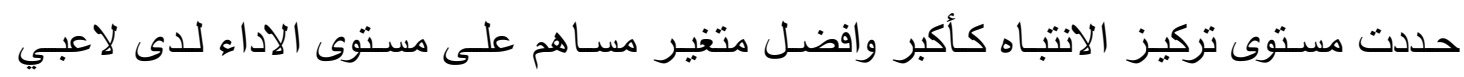

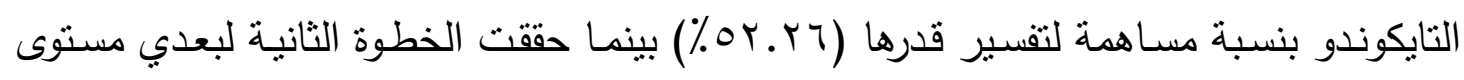

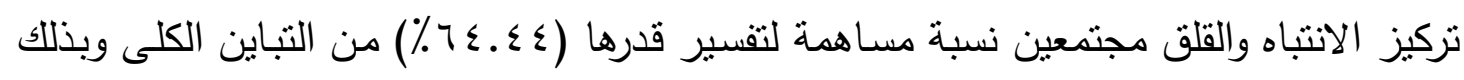

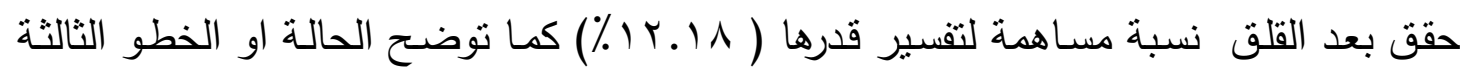

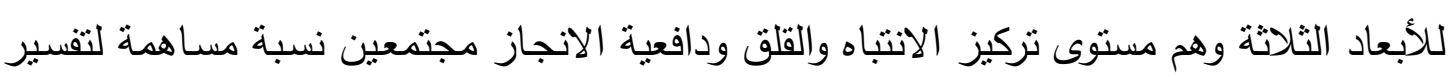

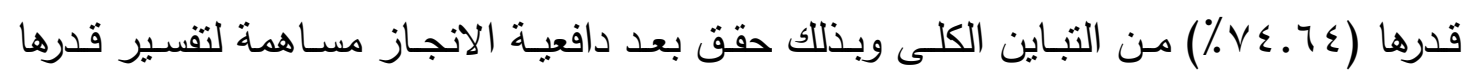

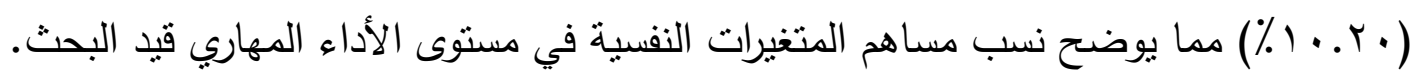
ومن خلال النتائج فانة قد أنشارت الدراسات العلمية الى مساهمة المتغيرات النفسية في

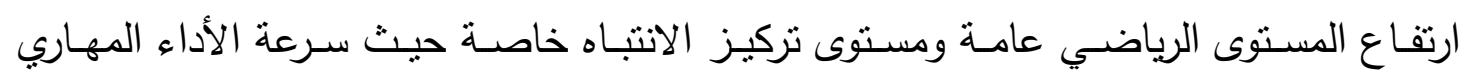

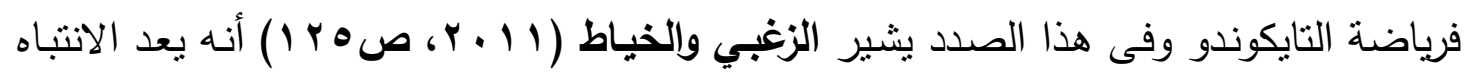

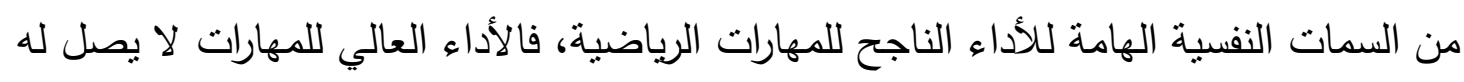

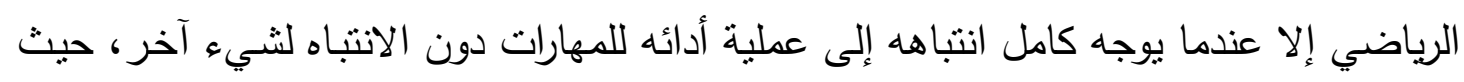

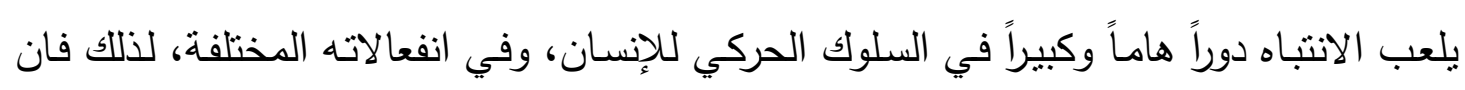

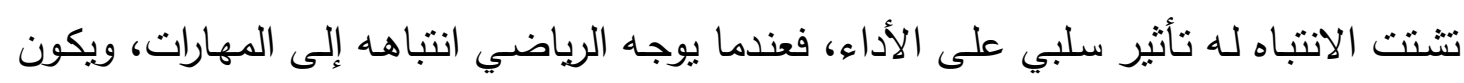

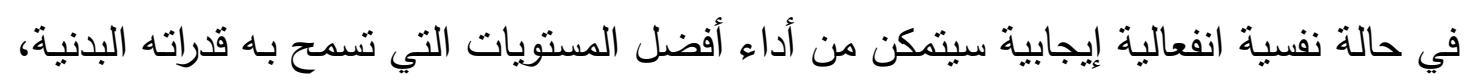

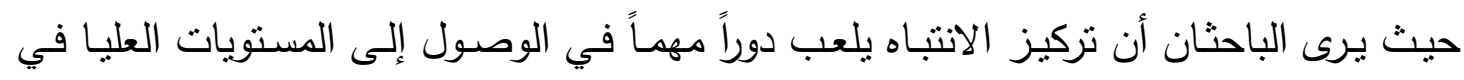

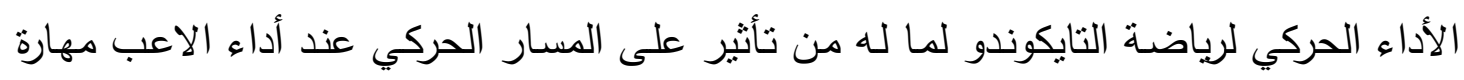

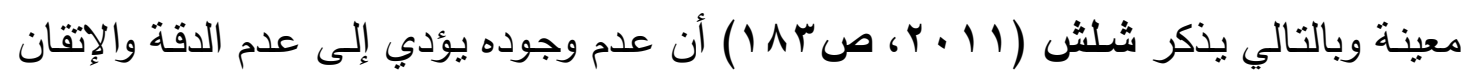

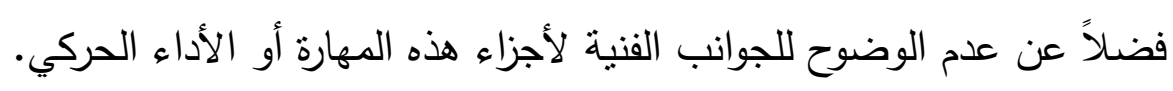
حيث تتبير (2012) الى أهمية الجانب النفسي في التدريب الرياضي للاعبي التايكوندو حيث قاموا بالتحقق مما إذا كان تصنيف المجهود المحسوس نفسيا يمكن استخدامه لتحديد أهداف التدريب. (RPE)

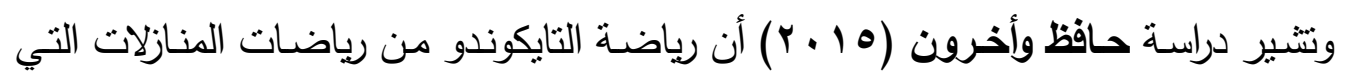
تطلب قدرات بدنية ومهاريةوخططية واعداد نفسي عالي لتؤهل اللاعبين للوصول إلى المستويات

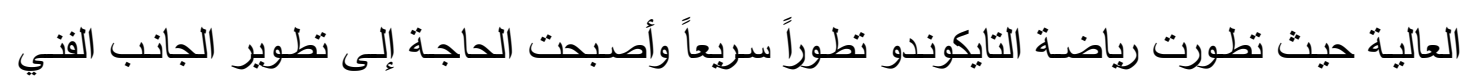


بالإضافة إلي ارتفاع مستوي اللياقة البدنية والمستوي الخططي أمرا جوهرياً حتي يستطيع اللاعب

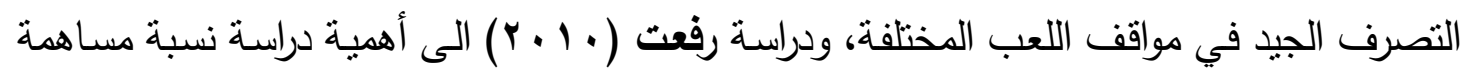

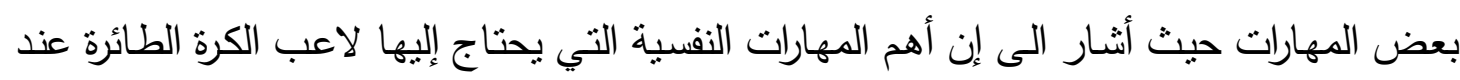
الأداء المهارة هي القدرة على التصور الذهني، القدرة على مواجهة القلق، القدرة على تركيز الانتباه. يُعد الجانب النفسي أهم المتطلبات الرئيسية المساهمة في رياضـة التايكوندو كونه يؤهل

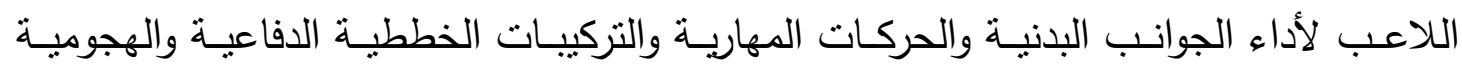

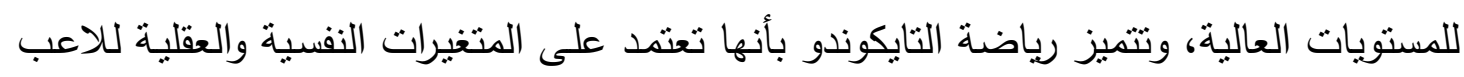

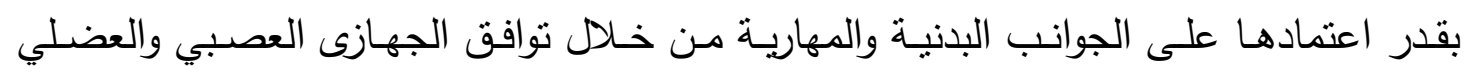

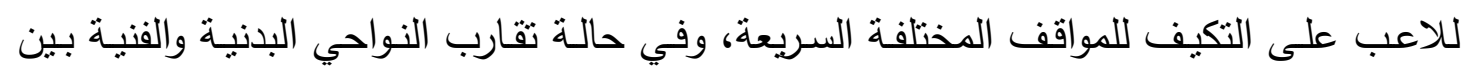

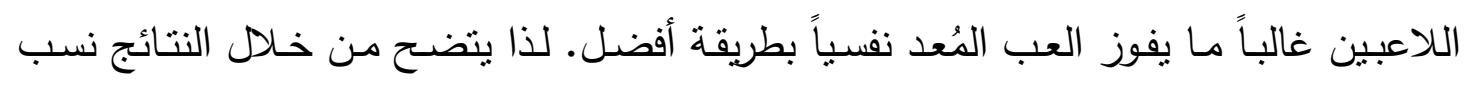

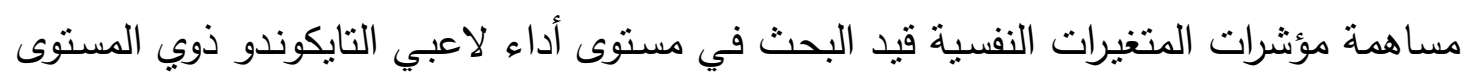

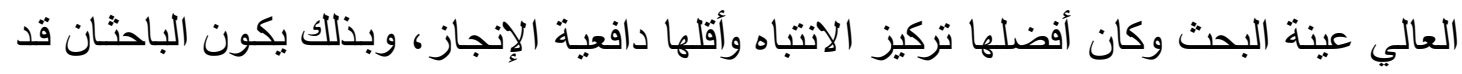

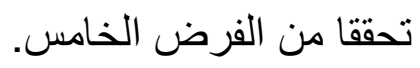

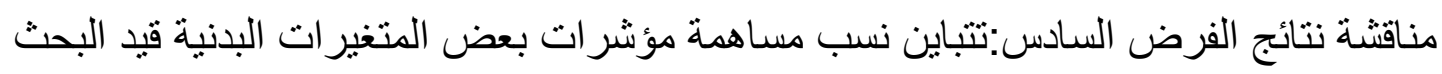

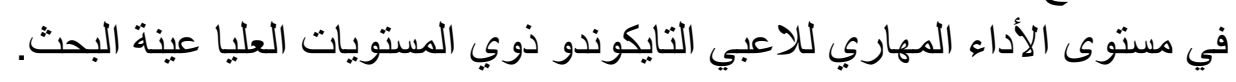

\section{بالرجوع إلى نتائج جدول (· (ץ).}

يتضح ما يلي: أظهرت نتائج تحليل المتغيرات البدنية لأفراد عينة البحث من لاعبي التايكوندو

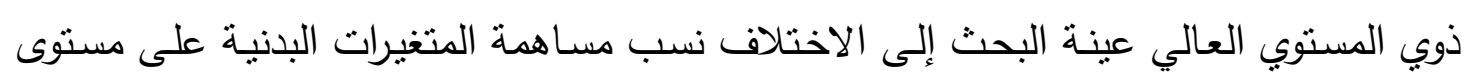
الأداء المهاري.

حيث أظهرت النتائج أن معامل التحديد في خمس حالات يشير الى ان الحالة الاولى قد

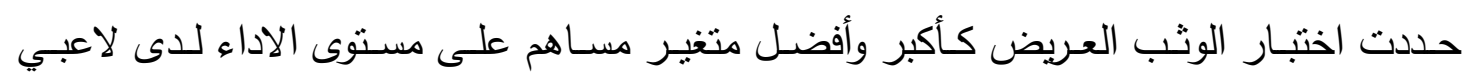

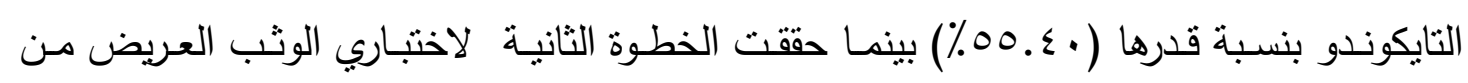

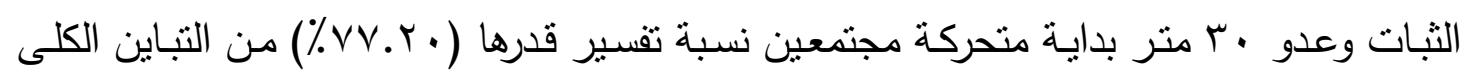

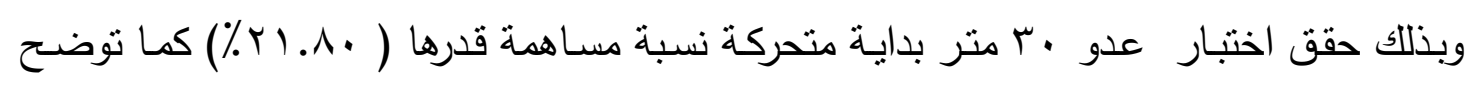

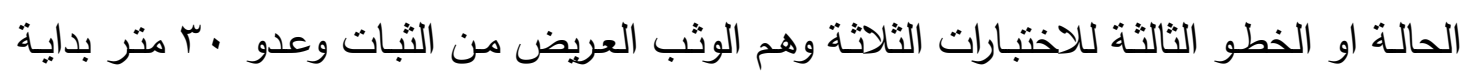

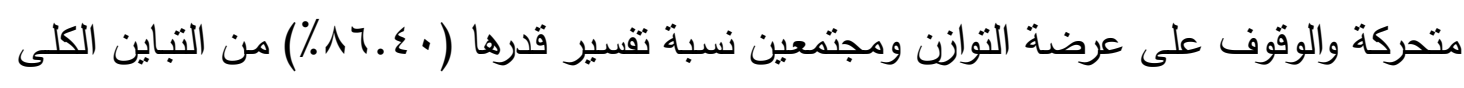

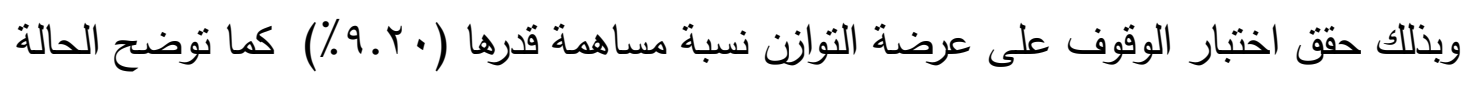

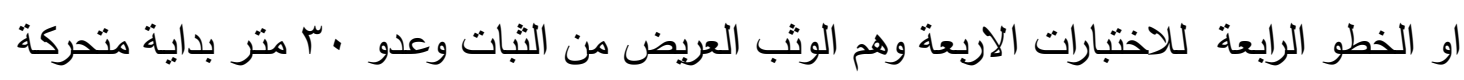

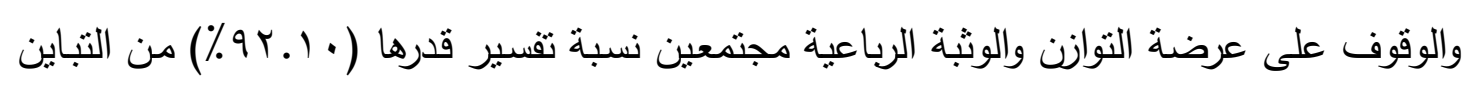




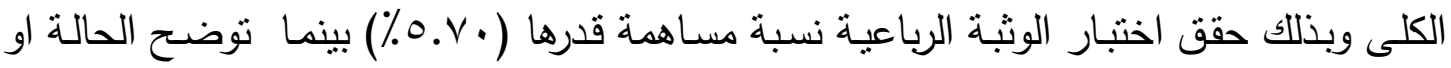

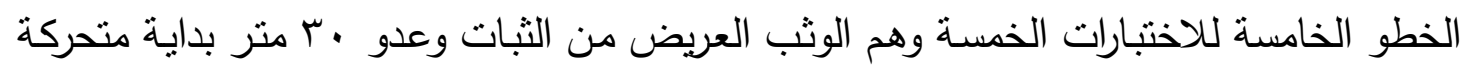
والوقوف على عرضـة التوازن والوثبة الرباعية ومرونـة مفصل الحوض مجتمعين نسبة تفسير

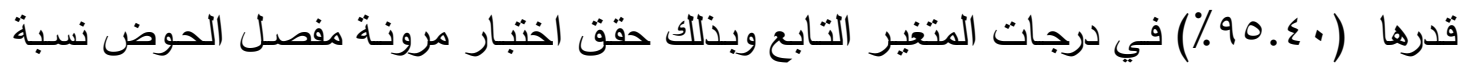

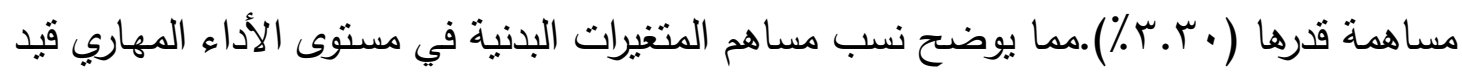
البحث.

ومن خلال النتائج فانة قد أشنارت الدراسات العلمية الى مساهمة المتغيرات البدنية في ارتفاع مستوى الأداء المهاري في رياضة التايكوندو وفى هذا الصدد يشيرحافظ وأحمد ومصطفي

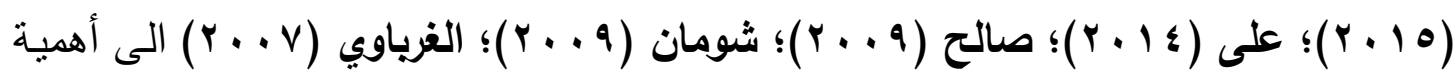
المتغيرات البدنية الخاصة برياضة التايكوندو في تطوير مستوى الأداء المهاري

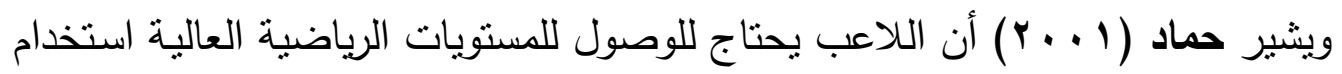

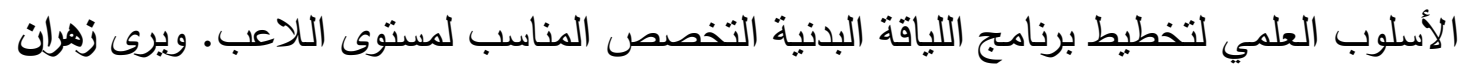

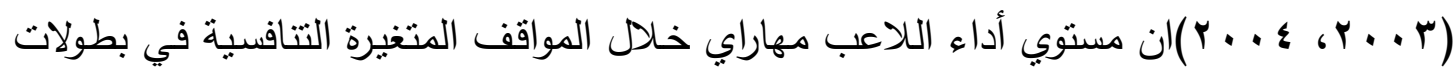
التايكوندو ولمواجهة متطلبات وظروف المباراة يحتاج الى مستويات البدنية لكي يكون لدية فرصة ادهاء للفوز في المباريات.

يُعد تطوير اللياقة البدنية الخاصة من أهم المتغيرات المساهمة في تطوير الأداء المهاري

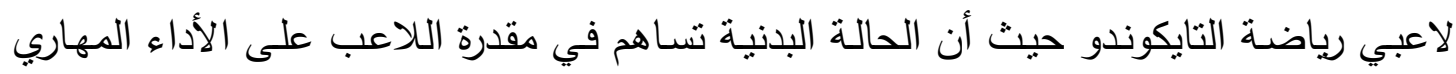

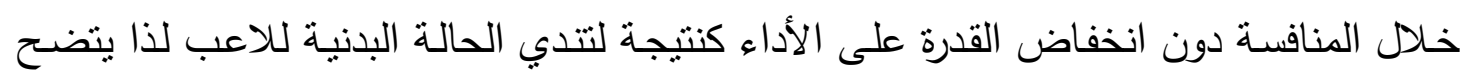

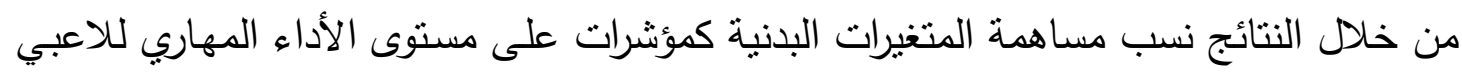

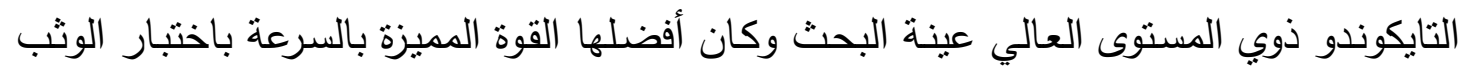
العريض من الثبات، وبذلك يكون الباحثان قد تحققا من الفرض السادس.

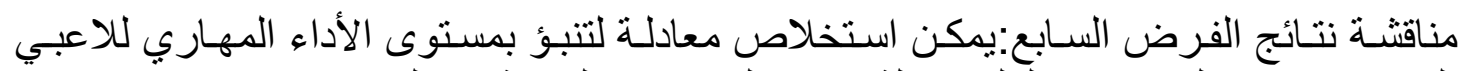
التايكوندو ذوب المستويات العليا بدلالة بعض المتغيرات النفسية قيد البحث.

بالرجوع إلى نتائج جدول (19 (1).

يتضح ما يلي: أظهرت نتائج تحليل الانحدار للمتغيرات النفسية لأفراد عينة البحث من لاعبي

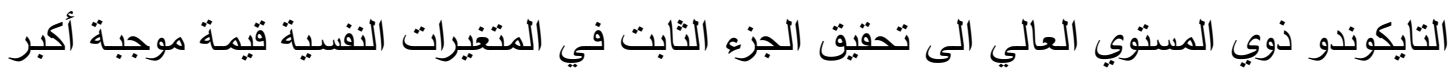

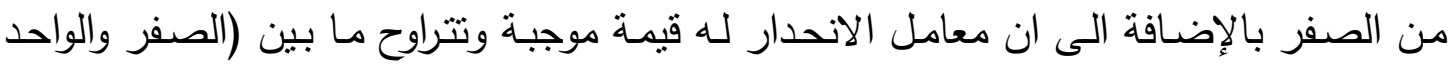


حيث أظهرت النتائجبعد نوافر الثروط النظرية لإجراء معامل الانحدار من حيث منطقية

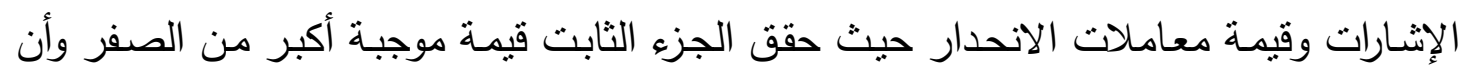

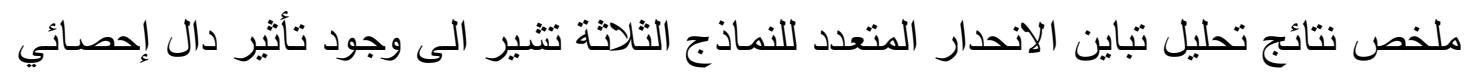

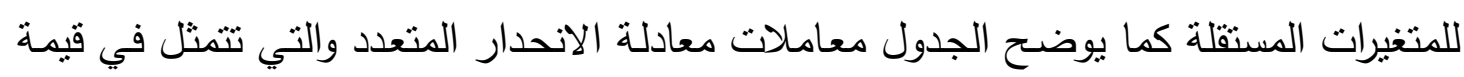

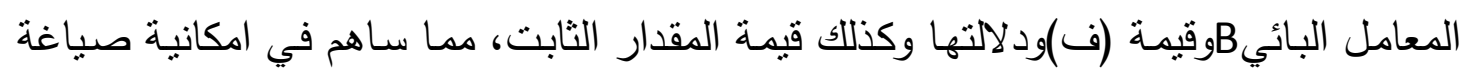

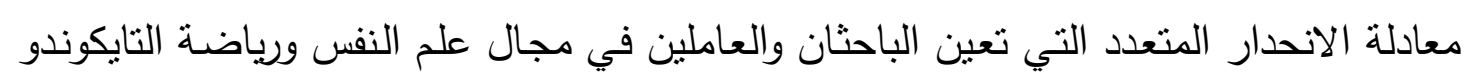

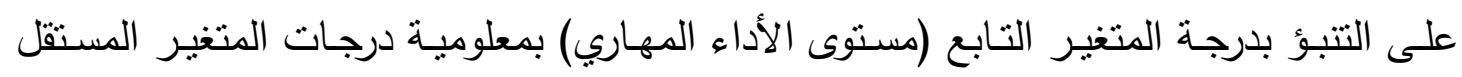
(المتغيرات النفسية) بالصورة النالية:

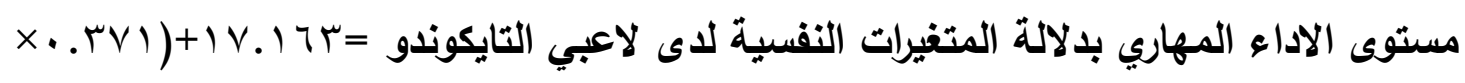

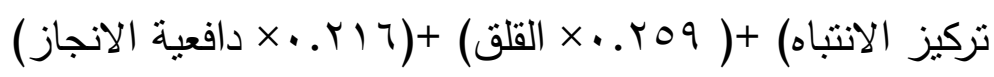

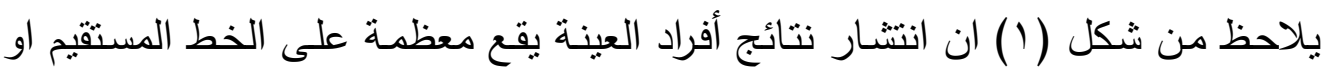

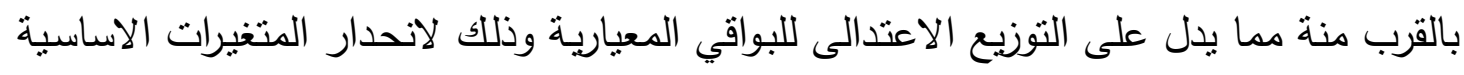

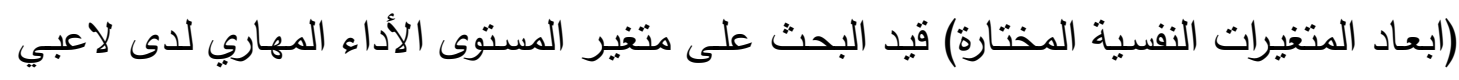
التايكوندو من المستويات العليا.

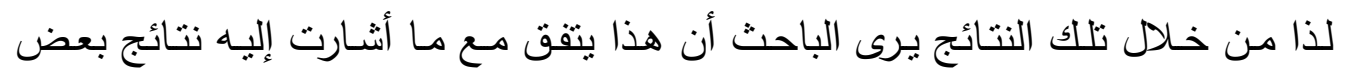

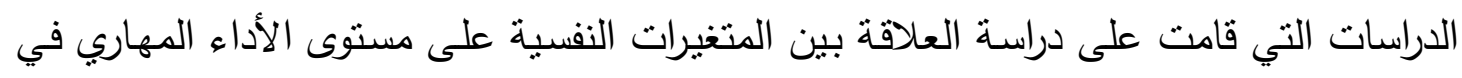

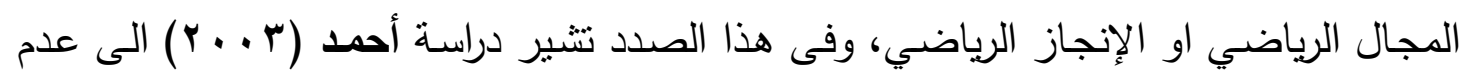

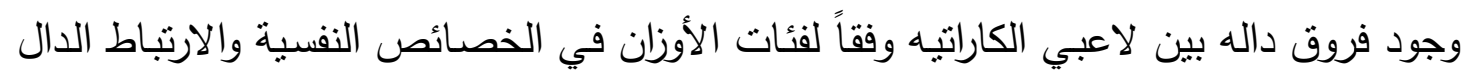

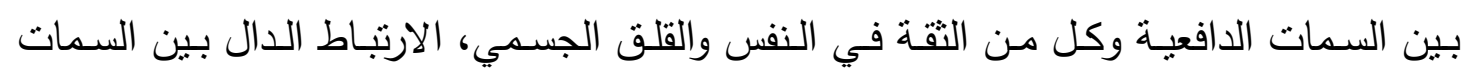
الدافعية خاصة وخصائص الانتباه.

ويذكر(Krane, Williams, (1993) أن التفوق والتقدم في نتائج ممارسـة الأنشطة

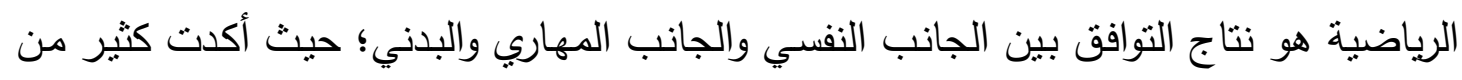

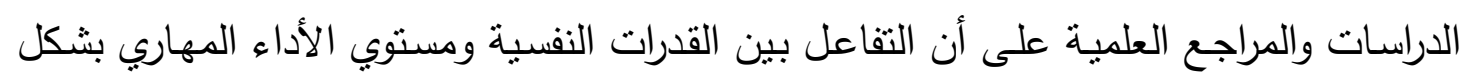

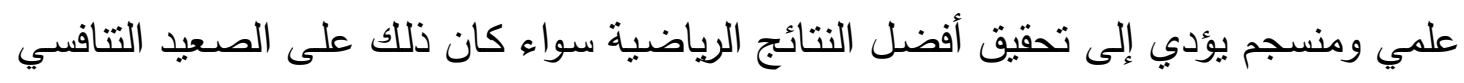
أو التدريبي للاعبين.

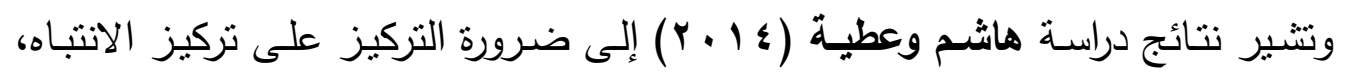

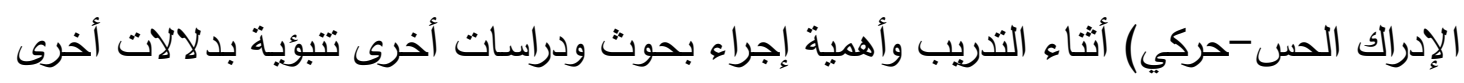
لمتغيرات لم يتطرق إليها الباحث في بحثه.

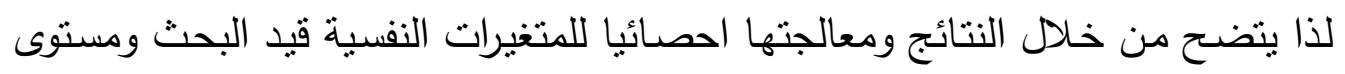

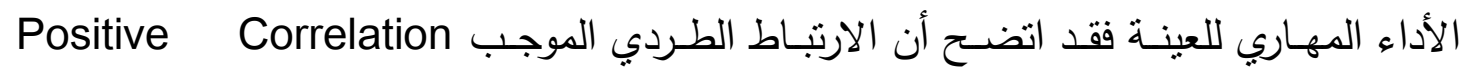


للمتغيرات قيد البحث أثنار الى أنه إذا تغير أحد المتغيرين(النفسي - مستوى الأداء المهاري) فان

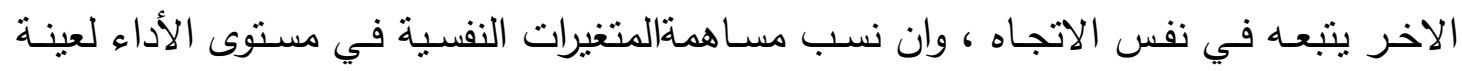

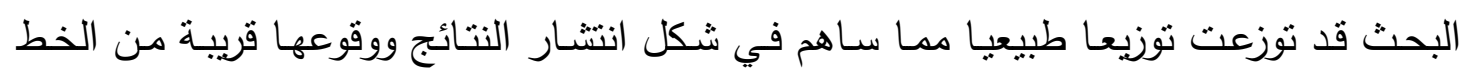

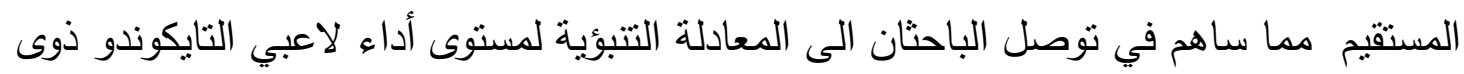

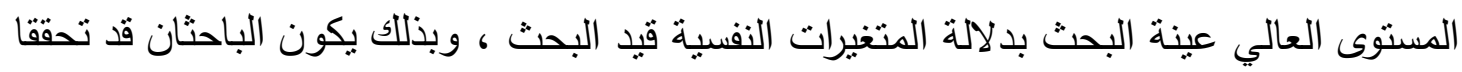
من الفرض السابع. 
مناقثنة نتائج الفرض الثامن:يمكن استخلاص معادلة لتنبؤ بمستوى الأداء المهاري للاعبي التايكوندو ذوي المستويات العليا بدلالة بعض المتغير ات البناتئنية قيد البحث.

بالرجوع إلنتائج جدول (· (r).

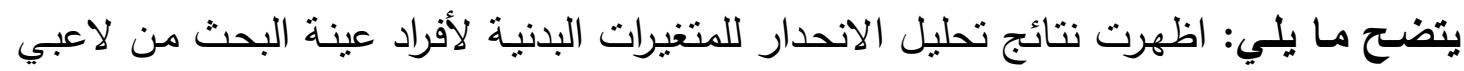

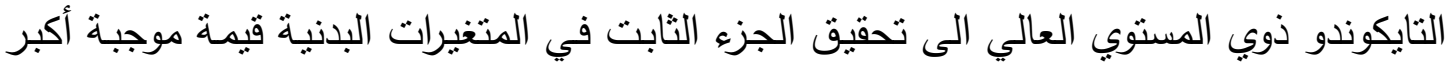

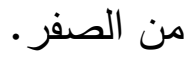

حيث أظهرت النتائجبعد نوافر الثروط النظرية لإجراء معامل الانحدار من حيث منطقية

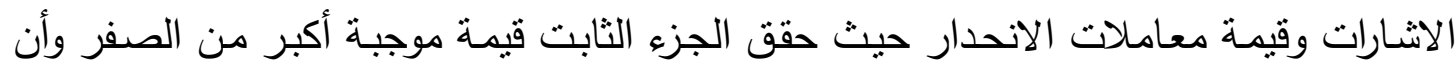

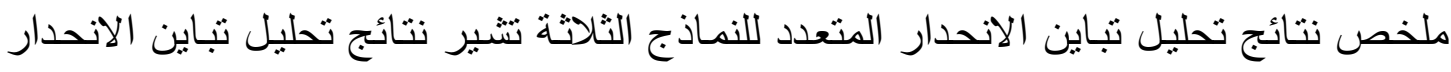

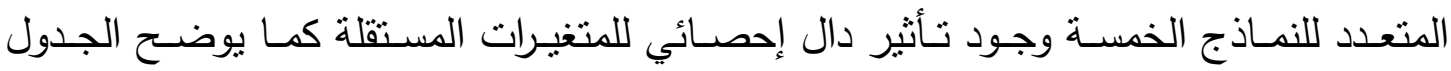

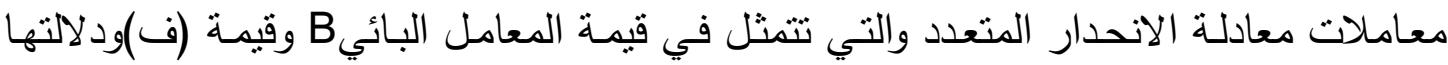
وكتلك قيمة المقدار الثابت مما ساهمفي امكان الباحثان لصياغة معادلة الانحدار المتعدد التي

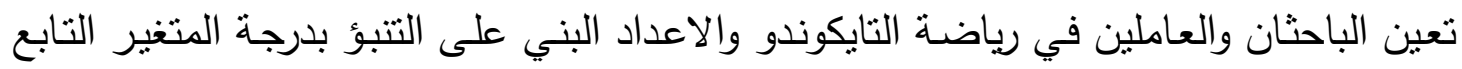

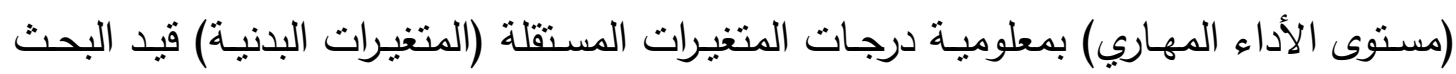

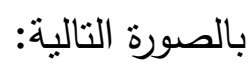

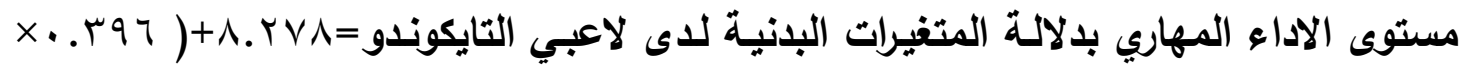

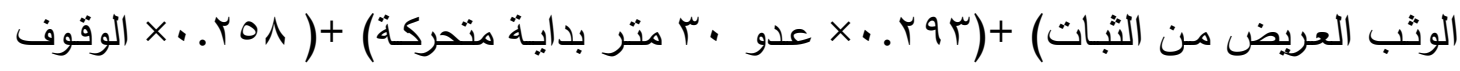

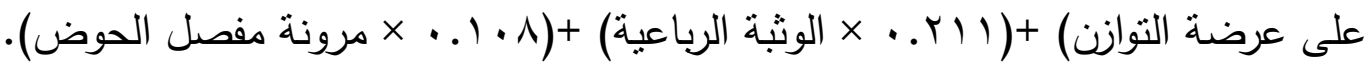

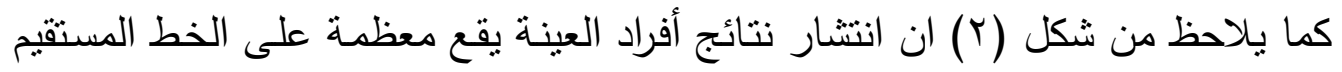

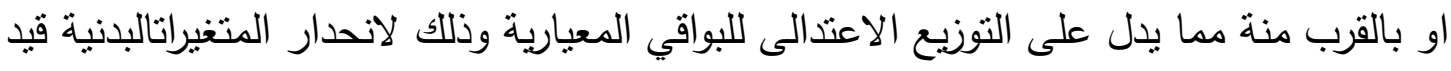
البحث على متغير المستوى المهاري لدى لاعبي التايكوندو من المستويات العليا عينة البحث.

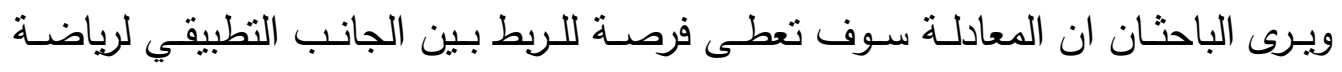

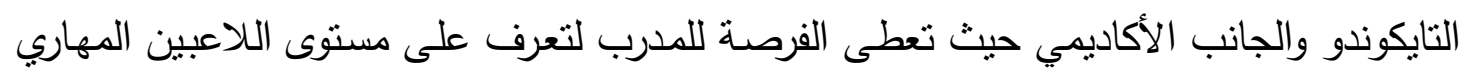

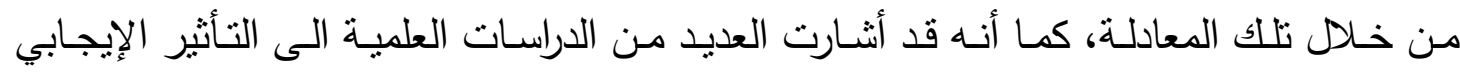

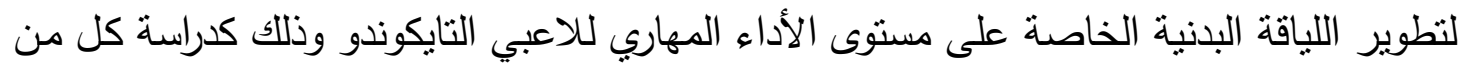

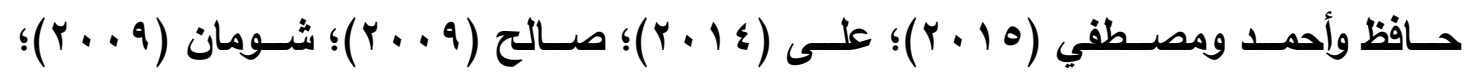

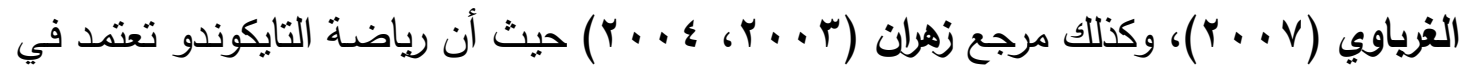

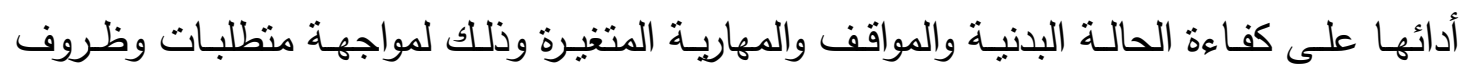

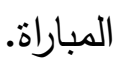

لذا يتضح من خلال النتائج ومعالجتها احصائيا للمتغيرات البدنية قيد البحث ومستوى الأداء المهاري للعينة فقد اتضح أن الارتباط الطردي الموجب للمتغيرات قيد البحث أثنار الى أنه 


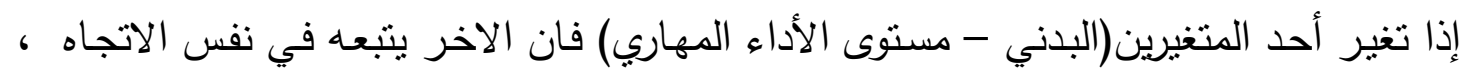

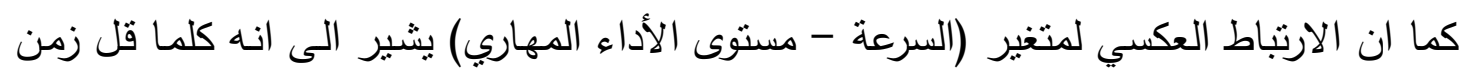

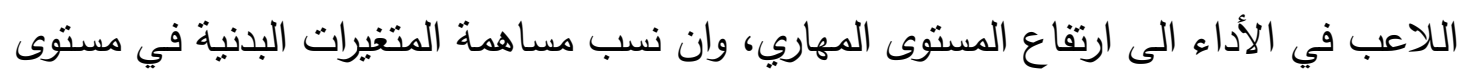

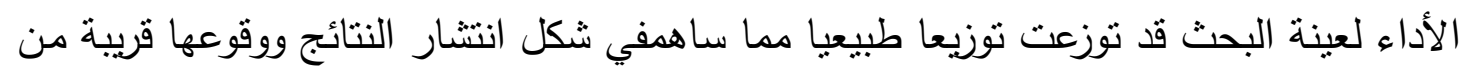

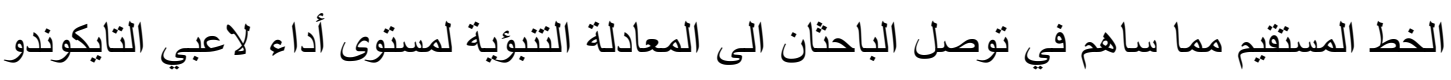

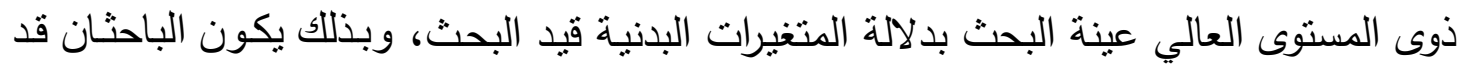
تحققا من الفرض الثنامن.

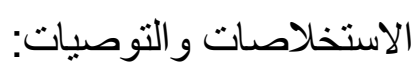
استخلاصات البحث:

قام الباحثان باستخراج النتائج وتقسيرها، وذلك للإجابة على تساؤلات الدراسة وتوصلا الى

الاستخلاصات النالية:

- صـلاحية مقياس المتخيـرات النفسية المختارة (القلق الرياضـي - دافعيـة الإنجـاز - تركيز الانتباه) لنطبيق على لاعبي رياضة التايكوندو ذوي المستوي الرياضي العالي.

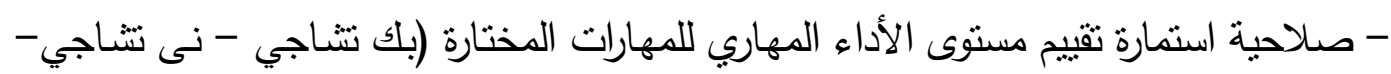
نارا تشاجي) لنطبيق على لاعبي رياضة التايكوندو ذوي المستوي الرياضي العالي.

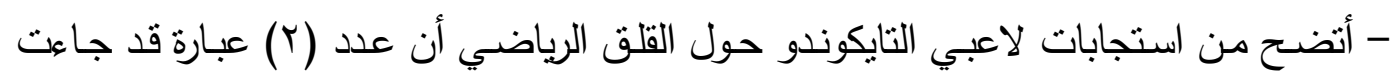

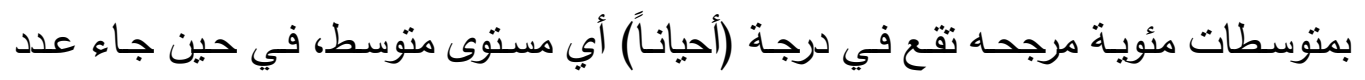

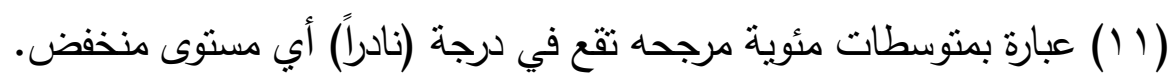

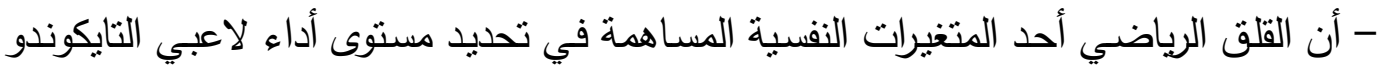

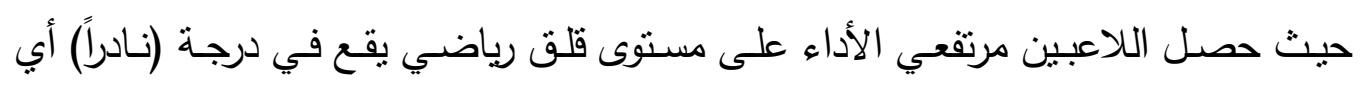

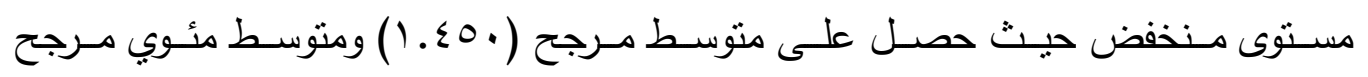
. (\% \% \&.rTr)

- أتضح من استجابات لاعبي التايكوندو حول الدافعية للإنجاز ومدى مساهتها في تحديد مستوى أدائهم أن عدد (9) عبارة قد جاءت بمتوسطات مئوية مرجحه تقع في درجة (دائماً)

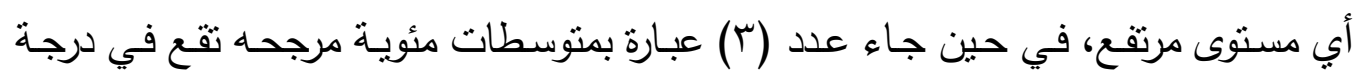
(أحباناً) أي مستوى منوسط، جاء عدد (1) عبارة بمنوسط مئوي مرجح تقع في درجة (نادراً) أبي مستوى منخفض. - أن الدافعية للإنجاز أحد المتغيرات النفسية المساهمة في تحديد مستوى أداء لاعبي التايكوندو

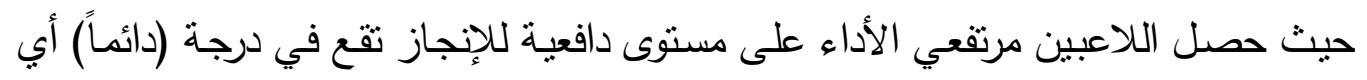




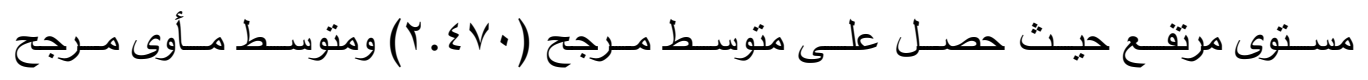

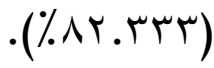

- أتضح من استجابات لاعبي التايكوندو حول تركيز الانتباه ومدى مساهنتها في تحديد مستوى

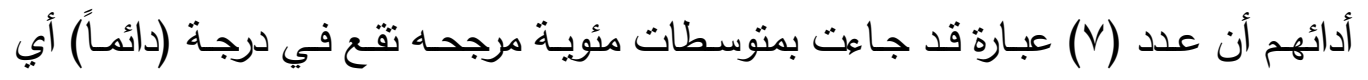
مستوى مرتفع، في حين جاء عدد (ع) عبارة بمتوسطات مئوية مرجحه تقع في درجة (أحياناً) أب مستوى منوسط.

- - حققت نتائج تقييم مستوى الاداء المهاري للاعبي التايكوندو ذوي المستوي العالي عينة

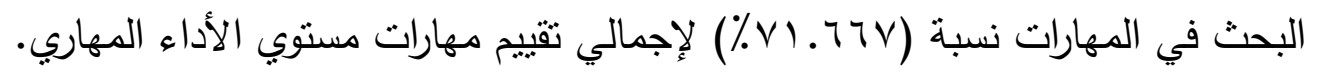

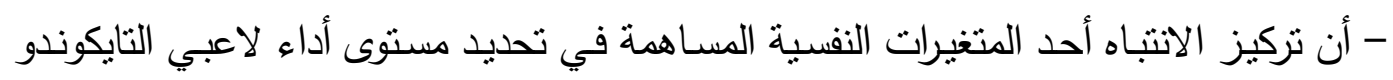
حيث حصل اللاعبين مرتفعي الأداء على مستوى تركيز للانتباه يقع في درجة (دائماً) أي لئي

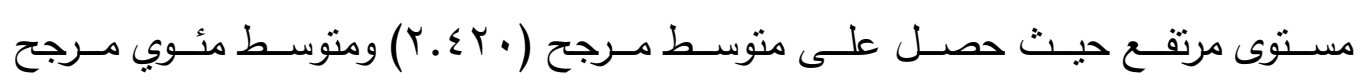

$$
\text { . (\%・. . . T V })
$$

- وجود ارتباط دال إحصائي عكسي سالب بين مستوى الأداء المهاري كتغير تابع وبين بعد القلق الرياضي بمقياس المتغيرات النفسية قيد البحث. - وجود ارتباط طردي موجب بين مستوي الأداء المهاري وبعد دافعية الإنجاز وتركيز الانتباه بمقياس المتغيرات النفسية قيد البحث. - أظهرت النتائج ترتيب المتغيرات النفسية كمؤشرات مساهمة في مستوى الاداء للاى لاعبي

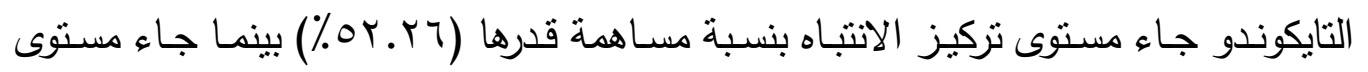

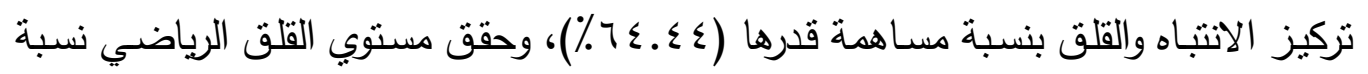

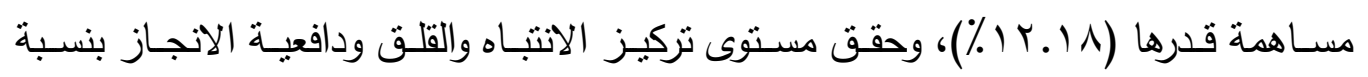

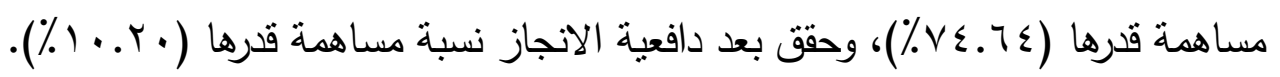

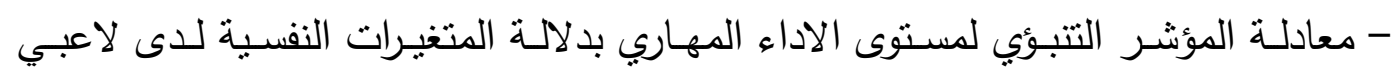

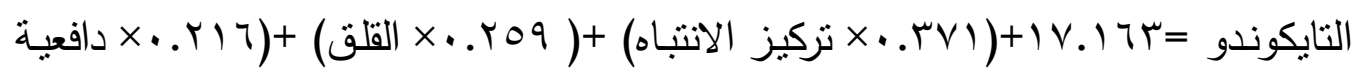

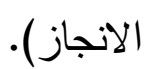
- وجود ارتباط دال إحصائي طردي موجب بين مسنوى الأداء كمتغير تابع وبين الاختبارات

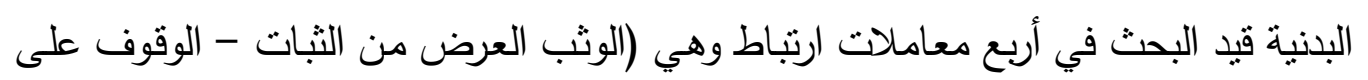

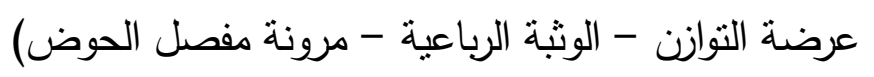

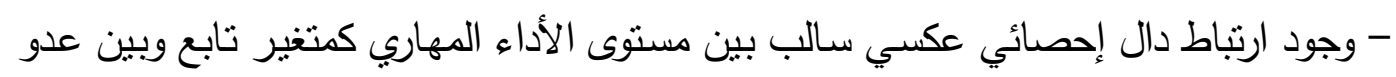
• r مثر بداية متحركة. 
- أظهرت النتائج ترتيب المتغيرات البدنية كمؤشرات مساهمة في مستوى الأداء المهاري للاعبي

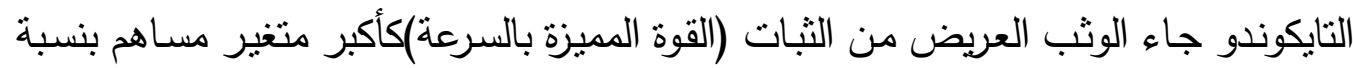

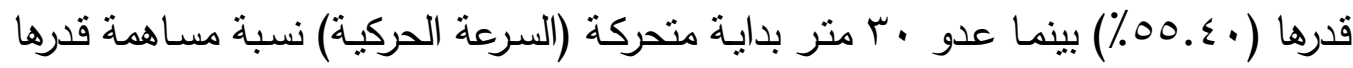

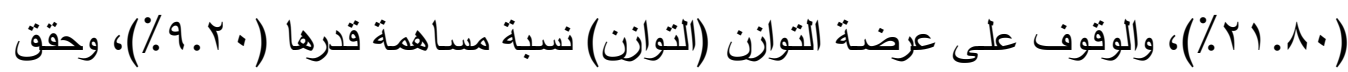

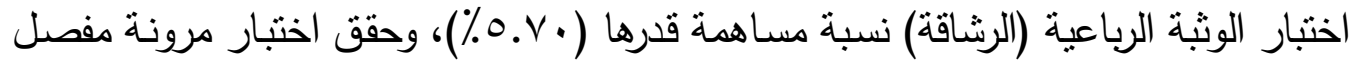
الحوض(مرونة) نسبة مساهمة قدرها (•r.r\%). - معادلة المؤشر التنبؤي لمسنوى الاداء المهاري بدلالة المتغيرات البدنية لدى لاعبي التايكوندو

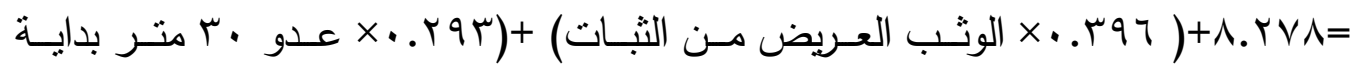

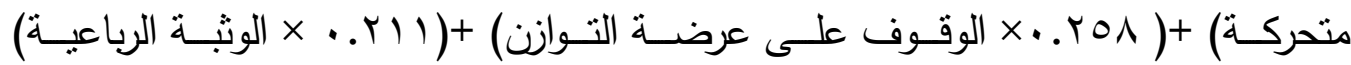

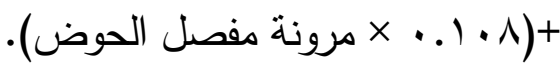

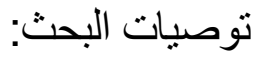

نظرا لما يتميز به هذا البحث من طبيعة وفى حدود ما أمكن التوصل إليه من استتناجات يمكن التوصية بما يلي:

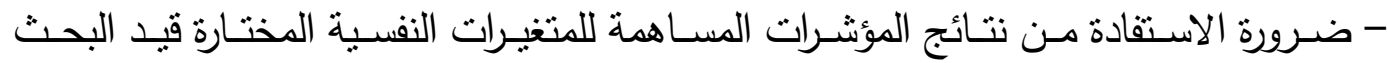

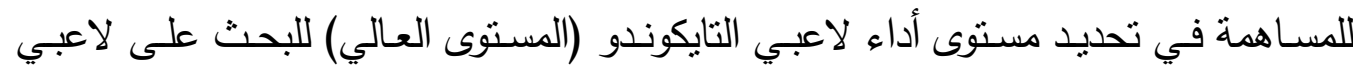
المستويات العليا في رياضة التايكوندو.

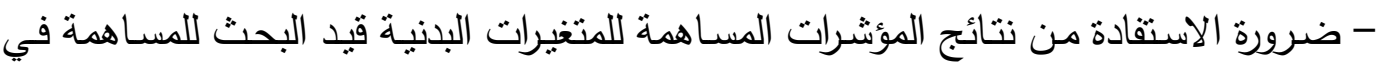
تحديد مستوى أداء لاعبي التايكوندو (المستوى العالي) للبحث على لاعبي المسنويات العليا في رياضة التايكوندو. - ضرورة استخدام العاملين في مجال تدريب رياضـة التايكوندو لمعادلة النتبؤ بمستوى الأداء المهاري للاعبي رياضة التايكوندو ذوي المستوي الرياضي العالي بدلالة المتغيرات (النفسية البدينة). - ضرورة استخدام استمارة تقييم مسنتوى الأداء المهاري للمهارات المختارة (بك تثـاجي - نسى

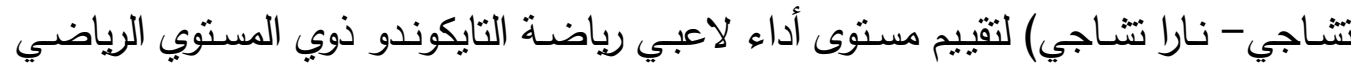

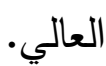
- ضـرورة استخدام مقياس المتغيرات النفسية المختارة (القلق الرياضـي - دافعيـة الإنجاز -

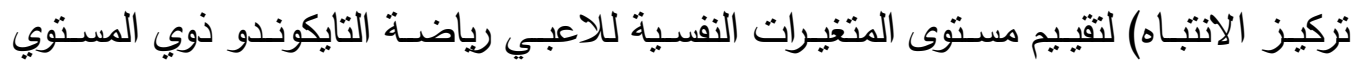
الرياضي العالي. 
- ضرورة تطبيق مقياس المتغيرات النفسية المختارة بشكل دوري على لاعبي الأنشطة الفردية

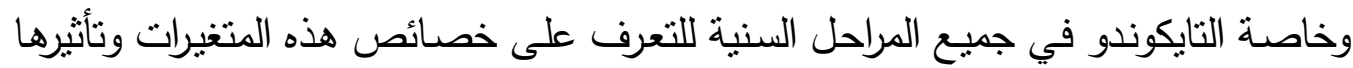
على اللاعبين واللاعبات والتعرف على جوانب القصور في ابعاد هذه الحالة وتطويرها.

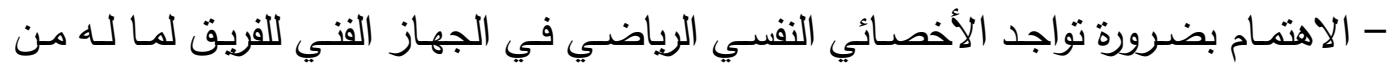
الأهية الكبيرة على الصحة النفسية للاعبين ومن نطوير الههارات النفسية. - الاستفادة من المتغيرات النفسية المختارة خلال الاعداد النفسي للاعبي التايكوندو. - الاستفادة من الدراسة الحالية في المجال النطبيقي للتعرف على مستويات المتغيرات النفسية لدى الرياضيين في المجال النتافسي.

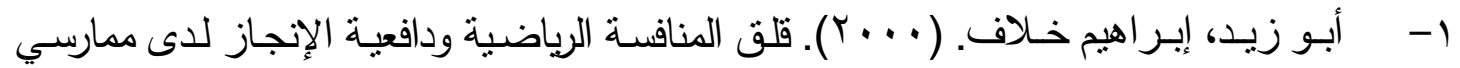
بعض الأثشطة الفرديـة والجماعيـة (دراسـة مقارنـة). بحث منشـور . المجلـة العلميـة

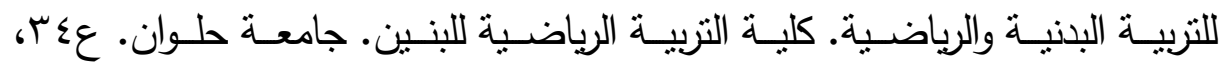

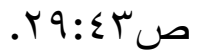

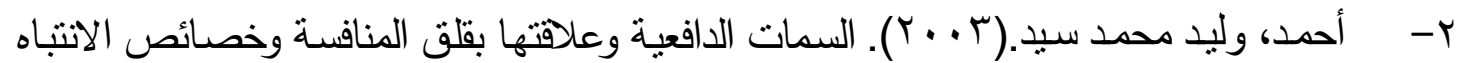
ومستوى أداء لاعبي الكاراتيـه. رسـالة دكتوراة غير منشـورة. كليـة التزبيـة الرياضية لاللبنين. جامعة الزقازيق.

r- - حافظ، سامي محب وأحمد، هاني عبد الدايم ومصطفي، حسام الدين إبراهيم. (10 • ب).تأثنير بعض التنرييات الخاصة على فاعلية الأداء الفني للركلة الأمامية الدائرية في مستوى الوجه (أولجل دوليو نتـاجي) للاعبي التايكوندو . المجلة العلمية لعلوم التربية البدنية

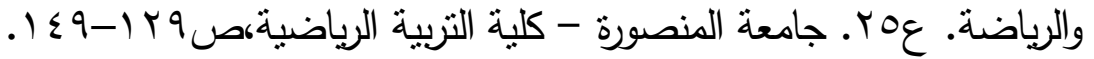

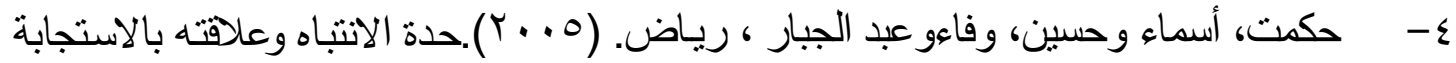
الحركيـة في لعبتي السباحة والكرة الطـائرة. بحث منشور ـ مجلـة التزبيـة الرياضية. 


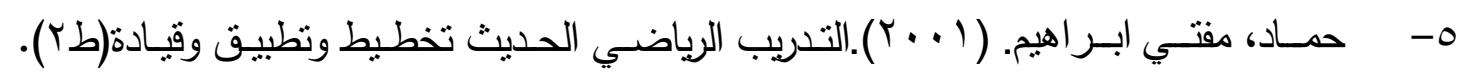
القاهرة: دار الفكر العربي.

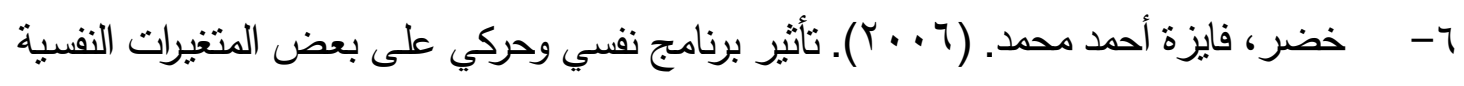

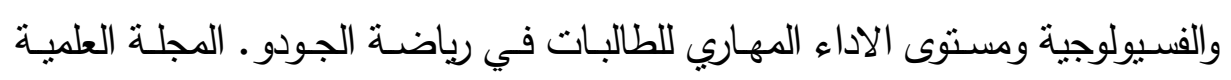

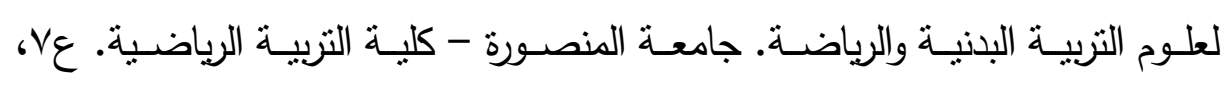
ص ص

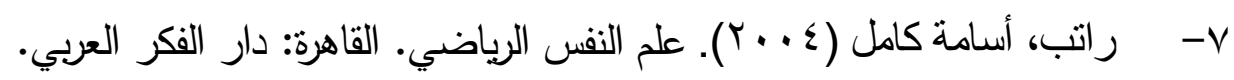

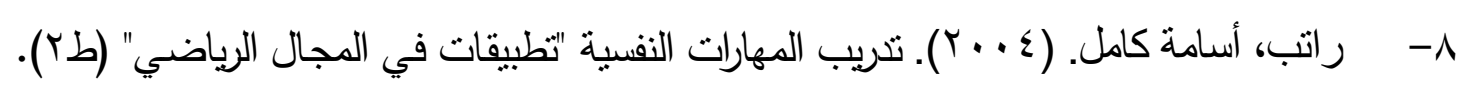

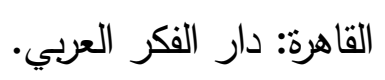

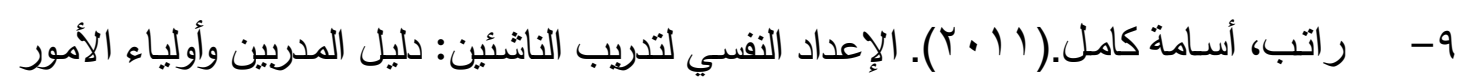

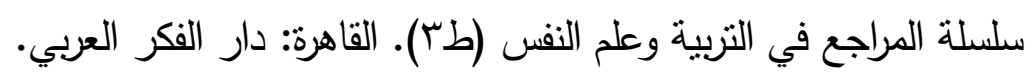

• 1- رفعت، محمد محمد.( ( • (Y).نسبة مساهمة بعض المهارات النفسية في لعبة الكرة الطائرة.

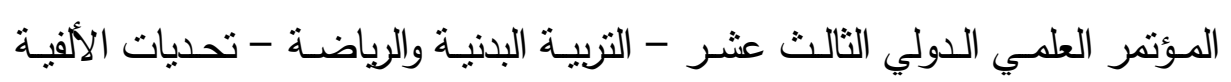

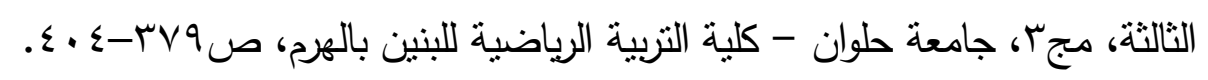

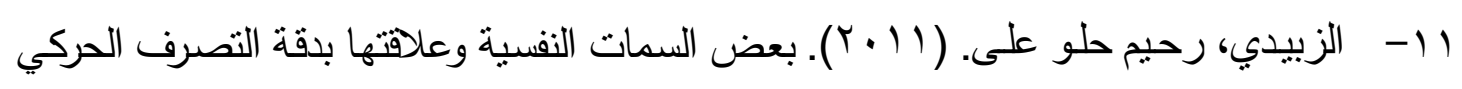
للاعبي المبارزة النانشئين بسلاح الثيش. بحث منشورة. مجلة علوم النتربية الرياضية. كلية التربية الرياضية. جامعة بابل. العراق.

r ا - الزغبي، صـالح عبد الله و الخياط، ماجد محمد.(1) (1).علم النفس الرياضي. عمان: دار الراية للنشر والنوزيع. 


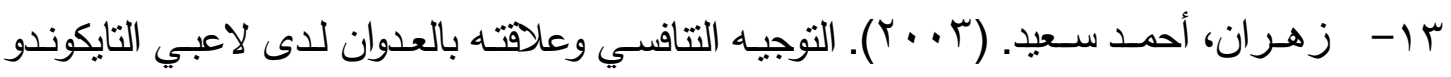
(دراســة تحليليـة مقارنـة). بحــث منشـور • المجلـة العلميـة بكليـة التربيـة الرباضـية،

$$
\text { جامعة طنطا. ص و }
$$

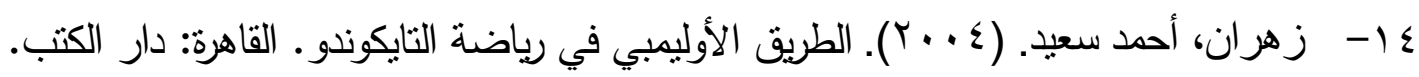

10 - زهران، أحمد سعيد. (ع . . ب). القواعد العلمية والفنية لرياضة التايكوندو . القاهرة: دار الكتب.

7 - - زهران، أحمد سعيد. (1 . ․ (خصائص الطلافة النفسية للاعبي المنتخب الكويتي للتايكوندو (دراسـة تحليليـة مقارنـة) . بحـث منشـور . المجلـة العلميـة للتربيـة البدنيـة والرياضـية.

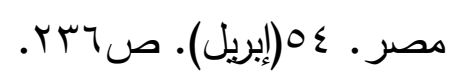

IV - زينة، أحمد محمد محمد وجاد، تامر محمد محمد. ( • ( • (Y).السمات الدافعية ودافعية الانجاز لاى لاعبي الملاكمة والمصـارعة: دراسـة مقارنة. المؤتمر العلمي الدولي الثالث عثر

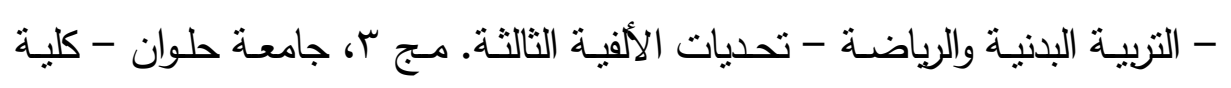

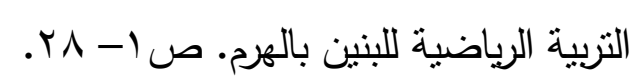

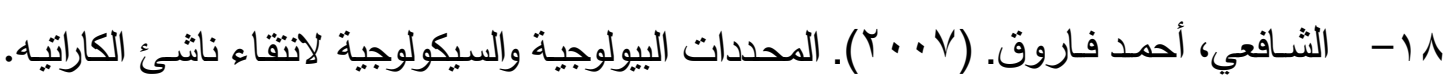
رسالة دكتوراه غير منشورة. كلية التزبية الرياضية للبنين. جامعة بنها.

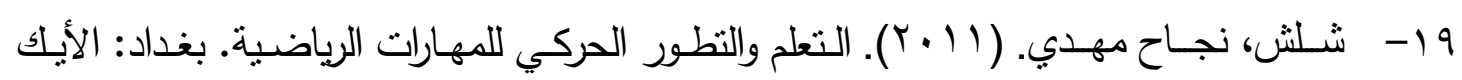
للتصميم والطباعة.

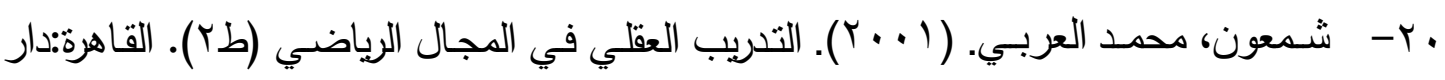

$$
\text { الفكر العربي. }
$$

ا - - شومان، حسام حسن أحمد.(9 + . r).تأثير برنامج تدربيي مقترح للإعداد الخططيعلى مستوى الإنجاز للاعبي التايكوندو تحت V اسنة. رسالة دكتوراة غير منشورة. كليـة التربية 


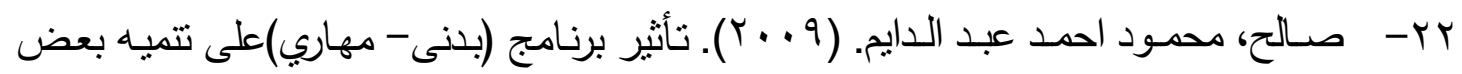

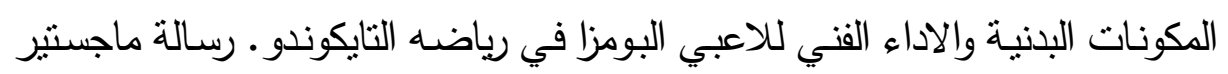
غير منشورة. كلية النزبية الرياضية. جامعة المنصورة.

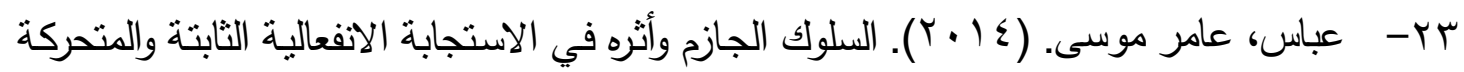

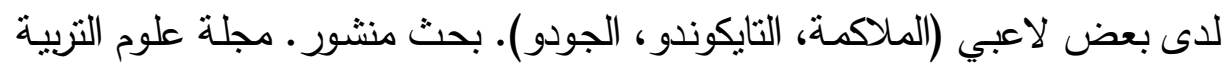
الرياضية. كلية التزبية الرياضية. جامعة بابل. V(1) (Y).

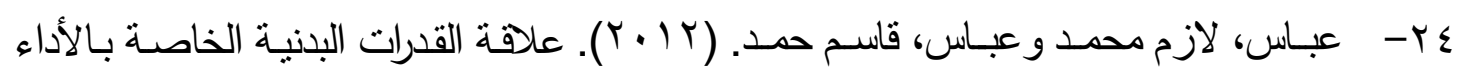

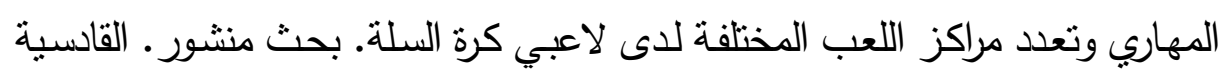

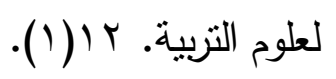

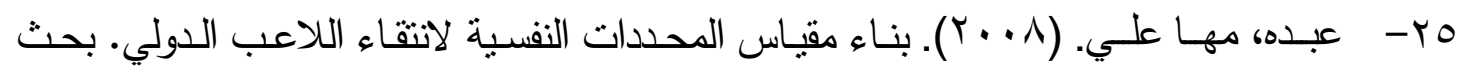

$$
\text { منشور، الرياضة (علوم وفنون). ابس(أكتوبر). }
$$

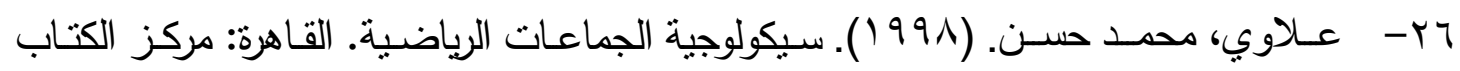
للنشر.

Y V - علاوى، محمد حسن.(1991).موسوعة الاختبارات النفسية للرياضيين. القاهرة: مركز الكتاب للنشر . للن

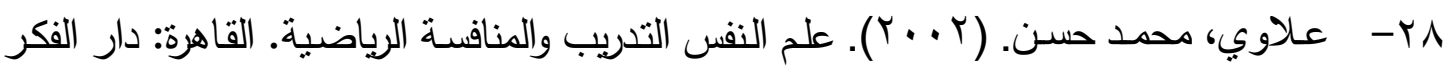

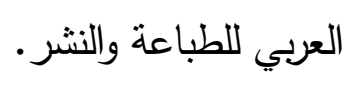

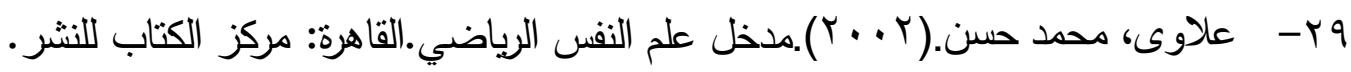

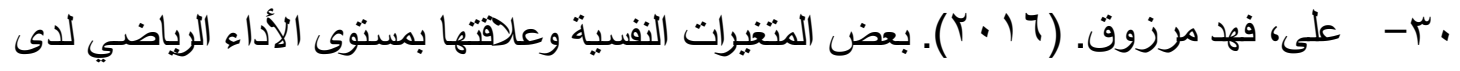
طلاب الجامعة. رسالة ماجستير غير منشورة. كلية البنات للآداب والعلوم والتربية.

$$
\text { جامعة عين شمس. }
$$

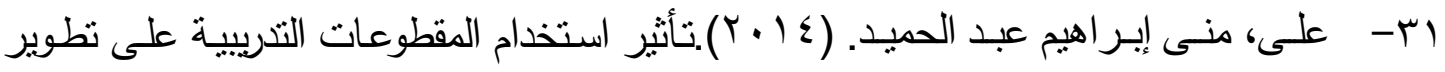

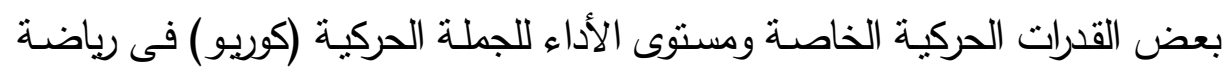

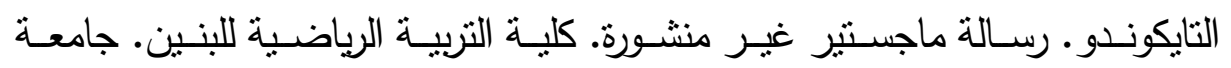

$$
\text { الإسكندرية. }
$$

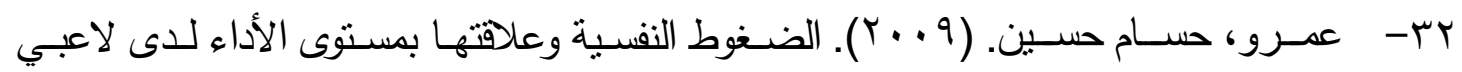
الجودو • رسالة ماجستير غير منشورة. كلية التربية الرياضية للبنين. جامعة بنها.

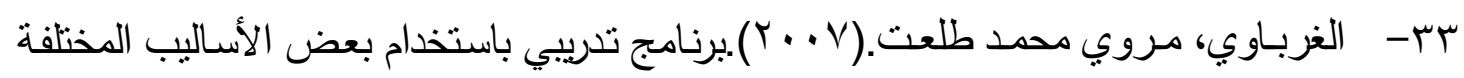

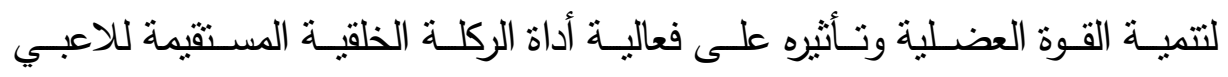


التايكوندو • رسالة دكتورات غير منشور . كلية التزبية الرياضية. جامعة طنطا.

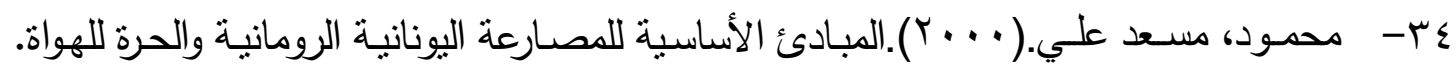
المنصورة: دار الطباعة للنشروالتوزيع.

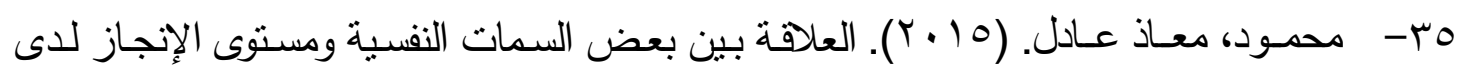
عدائي المسافات القصيرة في الجامعات الأردنية. رسالة ماجستير غير منشورة. كلية التربية الرياضية. جامعة اليرموك.الأردن.

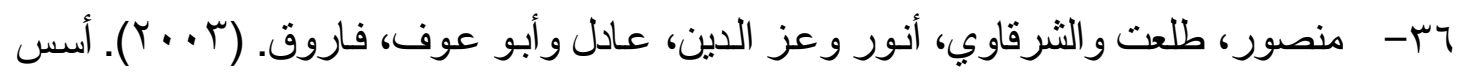
علم النفس العام. القاهرة: مكتبة الأنجلو.

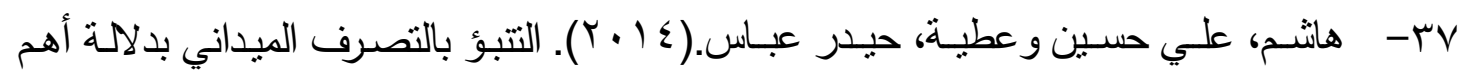
المهارات النفسية والقدرات العقلية للاعبي خط الدفاع لأندية دوري النخبة بكرة القدم. مجلة القادسية لعلوم التربية الرياضية. جامعة القادية. كلية التربية الرياضية. ؟ ( (Y).

$$
\text { ص ص1010 (10) }
$$

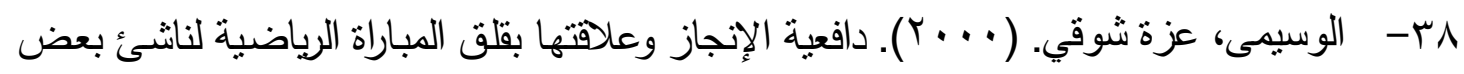

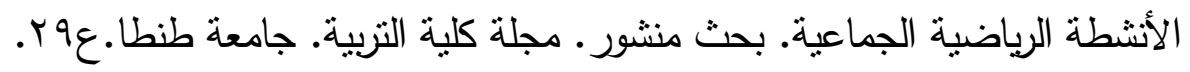




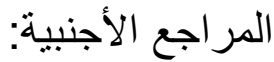

39- Ghorbanzadeh, B., \& Bayar, P. (2013). A Comparison of the PreCompetition and Post-Competition Anxiety Levels of Taekwondo Athletes. Life Science Journal, 10(2).

40- Gould, D., Eklund, R. C., \& Jackson, S. A. (1991). An in-depth examination of mental factors and preparation techniques associated with 1988 US Olympic team wrestling success. Grant report to USA Wrestling.

41- Jannah, M., Mulyana, O.P., \&Muthohir, T.C. (2015).Psychological profiles of Indonesian elite swimmers. Movement, Health \& Exercise, 4(2).

42- Kimiecik, J.C. \& Stein, G.L. (1992). Examining flow experiences in sport contexts: conceptual issues and methodological concerns. Journal of Applied Sport Psychology, 4, 144-160.

43- Matsumoto, d., takeuchi, m., ray, r., nakajima, t., iida, e., \&wakayama, h. (2001). The relationship between psychological characteristics. physical fitness. and physiology in judo athletes. Research Journal of Budo, 33(3), 1-11.

44- Meroño, L., Calderón, A., \& Hastie, P. (2015).Effect of a Sport Education season on psychological variables in youth swimmers. Cuadernos de Psicología del Deporte, 15(2), 35-46.

45- Perandini, L. A., Siqueira-Pereira, T. A., Okuno, N. M., SoaresCaldeira, L. F., \& Nakamura, F. Y. (2012). Use of session RPE to training load quantification and training intensity distribution in taekwondo athletes. Science \& Sports, 27(4), e25-e30.

46- Williams J.M., \&Krane, V. (1993).Psychological characteristics of Performance. In J.M. Williams (ED), Applied Sport Psychology: Personal Growth to peak Performance, May field, Mountain View, CA. P137. 


$$
1 . r
$$

